
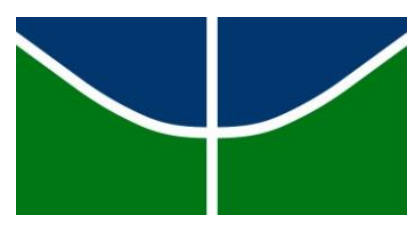

UNIVERSIDADE DE BRASÍLIA

INSTITUTO DE CIÊNCIAS BIOLÓGICAS

DEPARTAMENTO DE FITOPATOLOGIA

PROGRAMA DE PÓS-GRADUAÇÃO EM FITOPATOLOGIA

\title{
TRATAMENTO QUÍMICO DE SEMENTES DE FEIJÃO (Phaseolus vulgaris L.) PARA O CONTROLE DE Curtobacterium flaccumfaciens pv. flaccumfaciens
}

JOÃO GILBERTO ALVES VILLELA

Brasília - DF 


\section{JOÃO GILBERTO ALVES VILLELA \\ 12/0150069}

TRATAMENTO QUÍMICO DE SEMENTES DE FEIJÃO (Phaseolus vulgaris L.) PARA O CONTROLE DE Curtobacterium flaccumfaciens pv.flaccumfaciens

Dissertação apresentada à Universidade de Brasília como requisito parcial para a obtenção do título de Mestre em Fitopatologia pelo Programa de Pós Graduação em Fitopatologia

\section{Orientador}

Prof. Carlos Hidemi Uesugi, Doutor.

BRASÍLIA

DISTRITO FEDERAL - BRASIL 


\section{FICHA CATALOGRÁFICA}

Villela, João Gilberto Alves.

Tratamento químico de sementes de feijão (Phaseolus vulgaris L.) para o controle de Curtobacterium flaccumfaciens pv. flaccumfaciens. / João Gilberto Alves Villela.

Brasília, 2015.

132p. : il.

Dissertação de Mestrado. Programa de Pós-graduação em Fitopatologia, Universidade de Brasília, Brasília.

1. Tratamento de sementes - Controle.

I. Universidade de Brasília. PPG/FIT.

II. Título. 
Aos meus pais, Gilberto Mauro Villela e Valdemira Alves da Silva, pelo apoio incondicional e exemplo de amor.

Ao meu avô, José Alves da Silva (in memorian), pelo exemplo de simplicidade.

Dedico 


\section{AGRADECIMENTOS}

A Deus, pela presença constante em minha vida, dando-me proteção, coragem e força para conquistar meus objetivos.

Ao meu pai, Gilberto Mauro Villela, meu maior incentivador, pela valiosa ajuda na montagem e condução do experimento de campo.

A minha mãe, Valdemira Alves da Silva, pelo amor incondicional e confiança.

A minha irmã Nathalia Alves Villela, pelo companheirismo e ajuda na montagem do experimento de campo.

Ao Prof. Carlos Hidemi Uesugi, pela orientação, estímulo, incentivo, confiança e, sobretudo, pela amizade.

Ao técnico de laboratório de Bacteriologia Vegetal, Arenildo Soares, pelo conhecimento repassado.

Ao Prof. Ernandes Rodrigues, pelo conhecimento repassado e disponibilização da estrutura para ozonização das sementes.

Aos funcionários da Estação Experimental de Biologia, pela disposição e ajuda na condução dos experimentos.

Ao Adalberto Gatto, pelo fornecimento das sementes usadas nos experimentos.

Aos amigos que fiz durante o curso, Carina Lopes, Cleia Cabral, Débora Cervieri, Elenice Barbosa, Geane Fontes, Pedro Verlage, Rafaela Borges e Ricardo Nunes, os quais tornaram essa caminhada mais fácil e divertida.

Aos amigos de Unaí, Bruno Monteiro, Fabrício Vilela, Luís Augusto Fontanelle, Rafael Frees, Hudson Teodoro, pelos momentos de alegria e por sempre torcerem por mim.

Aos amigos da graduação, Antônio Nelson, Aureliano Dantas, Bernardo Coutinho, Bruno Costa, Thiago Peixoto, pessoas que sempre posso contar quando preciso. 
Ao CRUZEIRO ESPORTE CLUBE, pelas alegrias e emoções vividas.

A Universidade de Brasília e ao Departamento de Fitopatologia pela oportunidade de realização do curso.

Ao CNPq, pela concessão da bolsa de estudos.

A todo corpo docente do Departamento de Fitopatologia, pelos ensinamentos e conselhos repassados.

A todos os colegas e funcionários do Departamento de Fitopatologia, pelo apoio e companheirismo no decorrer desta caminhada.

Aos professores Luiz Eduardo Bassay Blum e Reinaldo José de Miranda Filho que gentilmente aceitaram participar da banca avaliadora.

A todos aqueles que, de alguma forma, contribuíram para a realização deste trabalho. 
Trabalho realizado junto ao Departamento de Fitopatologia do Instituto de Ciências Biológicas da Universidade de Brasília, sob orientação do Professor Carlos Hidemi Uesugi, com apoio do Conselho Nacional de Desenvolvimento Científico e Tecnológico (CNPq).

TRATAMENTO QUÍMICO DE SEMENTES DE FEIJÃO (Phaseolus vulgaris L.)

PARA O CONTROLE DE Curtobacterium flaccumfaciens pv. flaccumfaciens.

JOÃO GILBERTO ALVES VILLELA

12/0150069

DISSERTAÇÃO APROVADA em ______ por:

Prof. Dr. Luiz Eduardo Bassay Blum

Examinador Interno

Prof. Dr. Reinaldo José de Miranda Filho

Examinador Externo

Prof. Dr. Carlos Hidemi Uesugi

Orientador (Presidente)

BRASÍLIA - DISTRITO FEDERAL

BRASIL

2015 


\section{SUMÁRIO}

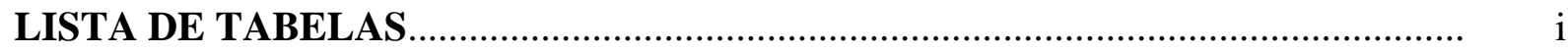

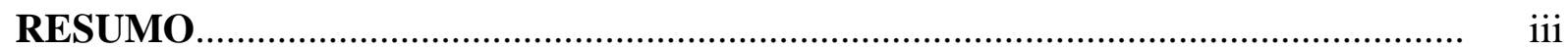

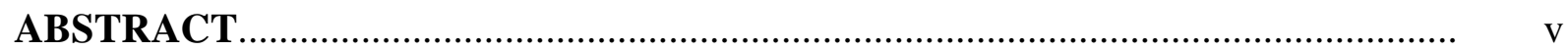

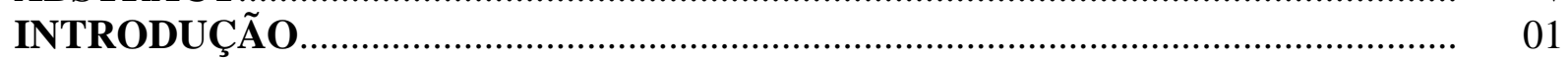

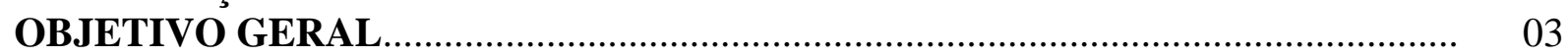

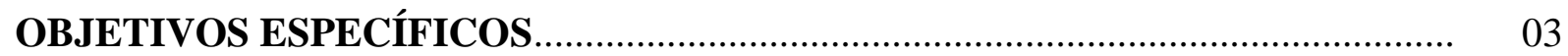

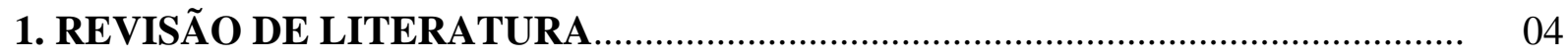

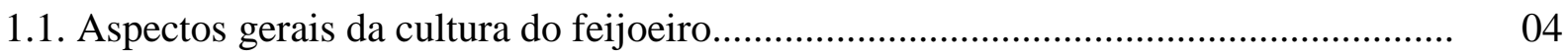

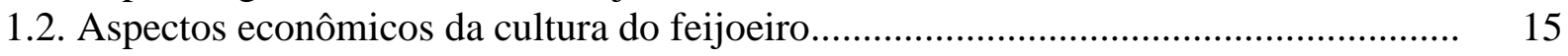

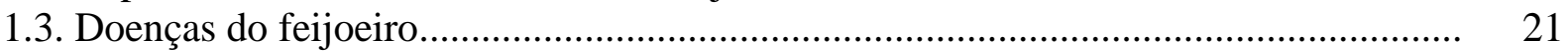

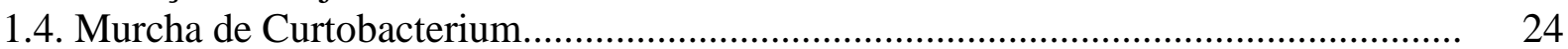

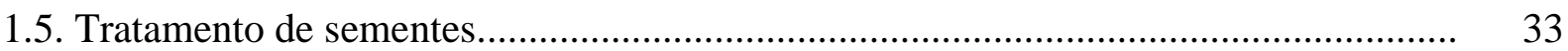

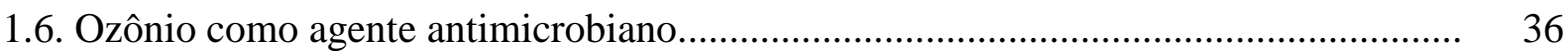

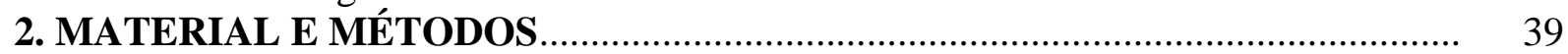

2.1. Isolado de Curtobacterium flaccumfaciens pv. flaccumfaciens................................. 39

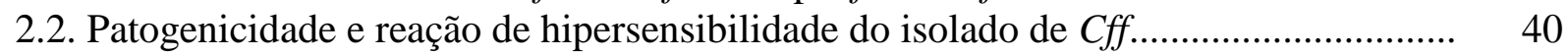

2.3. Sensibilidade "in vitro" de Cff a diferentes produtos fitossanitários........................... 41

2.3.1. Sensibilidade "in vitro" de Cff ao cobre................................................................... 42

2.3.2. Sensibilidade "in vitro" de Cff a casugamicina.......................................................... 43

2.3.3. Sensibilidade "in vitro" de Cff aos cloretos de benzalcônio....................................... 43

2.3.4. Sensibilidade "in vitro" de Cff ao ácido peracético.................................................... 44

2.4. Avaliação do efeito de diferentes tratamentos de sementes na erradicação de $C f f \ldots . . \quad 44$

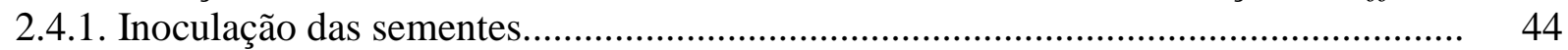

2.4.2. Tratamento de sementes de feijão com os produtos fitossanitários.......................... 45

2.4.3. Tratamento de sementes de feijão com vapores de etanol e metanol............................... 46

2.4.4. Tratamento de sementes de feijão com ozônio........................................................ 46

2.4.5. Avaliação da porcentagem de sementes contaminadas e eficiência na

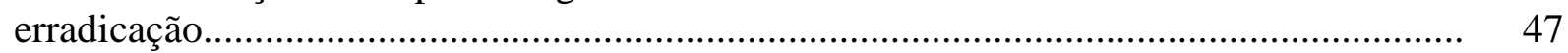

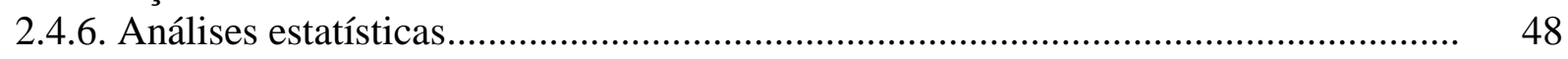

2.5. Experimento de campo...................................................................................... 48

2.5.1. Avaliação da emergência e velocidade de emergência de plântulas........................ 50

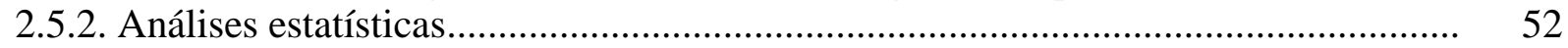

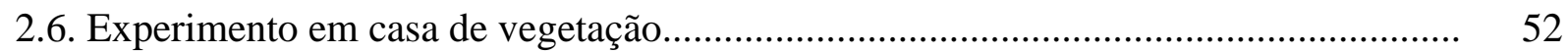

2.6.1 Avaliação da emergência e velocidade de emergência de plântulas........................... 53

2.6.2. Avaliação do desenvolvimento vegetativo......................................................... 54

2.6.3. Avaliação da incidência e severidade da Murcha de Curtobacterium........................ 54

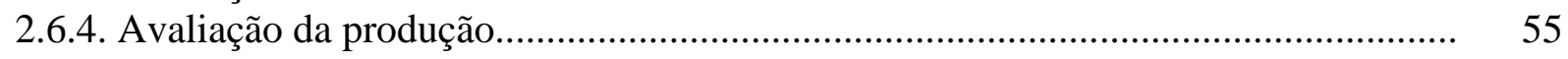

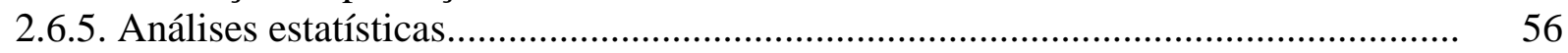

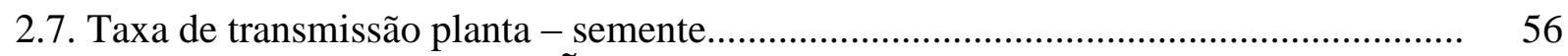

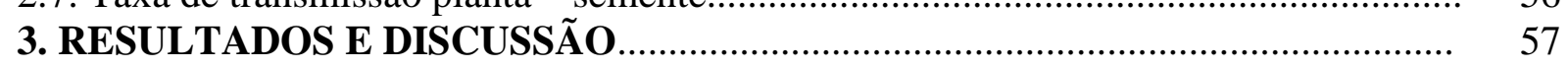

3.1. Isolado de Curtobacterium flaccumfaciens pv. flaccumfaciens ................................. 57

3.2. Patogenicidade e reação de hipersensibilidade do isolado de $C f f$.............................. 57

3.3. Sensibilidade "in vitro" de Cff a diferentes produtos fitossanitários............................ 57

3.4. Efeito dos diferentes tratamentos de sementes na erradicação de $C f f$............................ 62

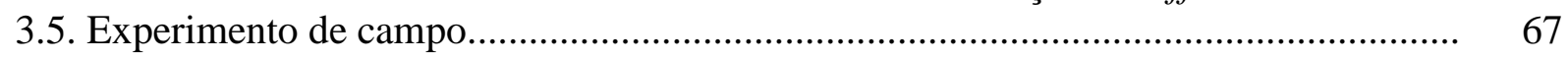

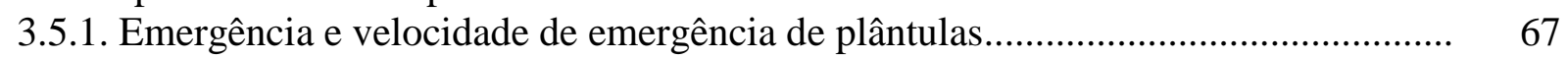

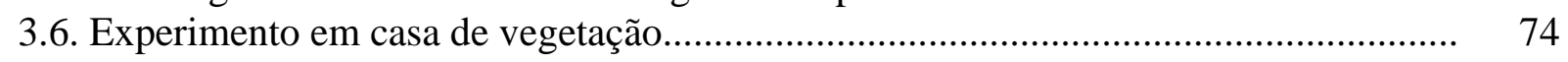

3.6.1. Emergência e velocidade de emergência de plântulas............................................ 74 


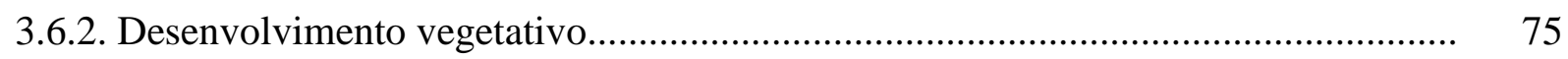

3.6.3. Incidência e severidade da Murcha de Curtobacterium............................................ 79

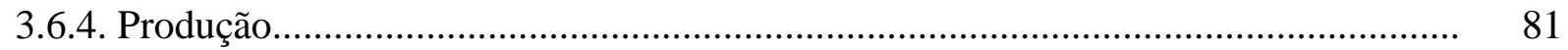

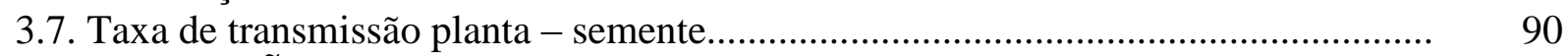

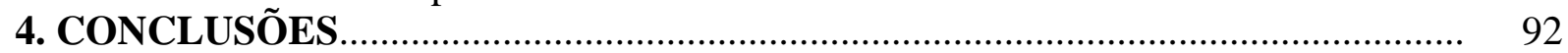

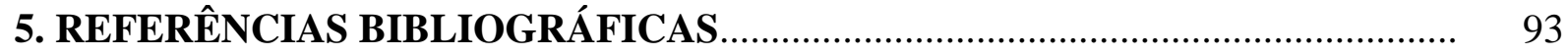

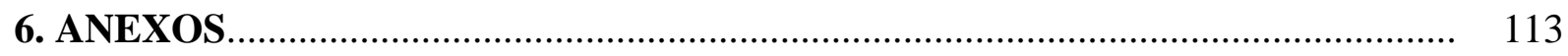




\section{LISTA DE TABELAS}

Tabela 1.1. Estádios fenológicos do feijoeiro.

Tabela 1.2. Área colhida, produção e rendimento de feijão nos principais países produtores $(2010$ - 2013).

Tabela 1.3. Área colhida, produção e produtividade de feijão nos Estados maiores produtores (2008/2009 - 2012/2013).

Tabela 1.4. Produção, área plantada e rendimento nacional e por região geográfica nas safras 2011/2012 e 2010/2013....

Tabela 1.5. Balanço da oferta e demanda de feijão no Brasil (1.000 toneladas), 2008/2009 a 2012/2013....

Tabela 2.1. Produtos fitossanitários selecionados para avaliação da sensibilidade "in vitro", do isolado UnB 1376 de Curtobacterium flaccumfaciens pv. flaccumfaciens.

Tabela 2.2. Volume de solução estoque necessário para obtenção da concentração de cobre metálico desejada, em meio de cultura.

Tabela 2.3. Atributos químicos na camada de 0 a $0,20 \mathrm{~m}$ do Latossolo Vermelho Distrófico da área experimental antes da instalação do ensaio, em Unaí - MG.

Tabela 2.4. Temperaturas máxima, mínima e compensada média, precipitação pluvial e umidade relativa do ar observadas entre os dias 5 e 12 de dezembro de 2013, em Unaí, Estado de Minas Gerais, na condução dos testes de emergência das plântulas e índice de velocidade de emergência em campo.

Tabela 3.1. Porcentagem do número médio de colônias de Curtobacterium flaccumfaciens pv. flaccumfaciens observado em meio CYE-glycerol contendo produtos cúpricos em diferentes concentrações em relação ao meio sem cobre.

Tabela 3.2. Número de colônias (UFC/mL) de Curtobacterium flaccumfaciens pv. flaccumfaciens em meio de cultura 523 suplementado com casugamicina em diferentes concentrações. UnB, Brasília, DF, 2014.

Tabela 3.3. Número de colônias (UFC/mL) de Curtobacterium flaccumfaciens pv. flaccumfaciens em meio de cultura 523 suplementado com cloretos de benzalcônio em diferentes concentrações. UnB, Brasília, DF, 2014.

Tabela 3.4. Número de colônias (UFC/mL) de Curtobacterium flaccumfaciens pv. flaccumfaciens em meio de cultura 523 suplementado com ácido peracético em diferentes concentrações. UnB, Brasília, DF, 2014.

Tabela 3.5. Número e localização de colônias de Curtobacterium flaccumfaciens pv. flaccumfaciens em sementes de feijão inoculadas por meio do método da imersão em suspensão bacteriana. UnB, Brasília, DF, 2014.

Tabela 3.6. Porcentagem de sementes feijão inoculadas com Curtobacterium flaccumfaciens pv. flaccumfaciens, com a presença do patógeno, após diferentes tratamentos. UnB, Brasília, DF, 2014.

Tabela 3.7. Número de colônias em sementes de feijão inoculadas com Curtobacterium flaccumfaciens pv. flaccumfaciens, após diferentes tratamentos. UnB, Brasília, DF, 2014.

Tabela 3.8. Efeito de diferentes tratamentos de sementes de feijão na emergência em campo. UnB, Brasília, DF, 2014.

Tabela 3.9. Efeito de diferentes tratamentos de sementes de feijão no índice de velocidade de emergência em campo. UnB, Brasília, DF, 2014.

Tabela 3.10. Efeito de diferentes tratamentos de sementes de feijão na emergência de 
plântulas em vaso (EV) e no índice de velocidade de emergência (IVE), em condições de casa de vegetação. UnB, Brasília, DF, 2014.

Tabela 3.11. Efeito de diferentes tratamentos de sementes no peso em gramas de matéria verde de parte aérea (PMV) de plântulas em feijoeiro aos 15 dias após a semeadura. UnB, Brasília, DF, 2014.

Tabela 3.12. Efeito de diferentes tratamentos de sementes no número de trifólios (NT) e na altura da planta (ALT) aos 28 dias após a semeadura. UnB, Brasília, DF, 2014.

Tabela 3.13. Efeito de diferentes tratamentos de sementes na incidência (\%) de plantas de feijoeiro com sintomas de Murcha de Curtobacterium, causada por Curtobacterium flaccumfaciens pv. flaccumfaciens, aos 30, 45 e 60 dias após a semeadura (DAS). UnB, Brasília, DF, 2014.

Tabela 3.14. Efeito de diferentes tratamentos de sementes na severidade da doença, aos 30, 45 e 60 dias após a semeadura, e área abaixo da curva de progresso da Murcha de Curtobacterium, causada por Curtobacterium flaccumfaciens pv. flaccumfaciens. UnB, Brasília, DF, 2014

Tabela 3.15. Efeito de diferentes tratamentos de sementes de feijão no número de vagens (NV) e no número de grãos por parcela (NG). UnB, Brasília, DF, 2014.

Tabela 3.16. Efeito de diferentes tratamentos de sementes de feijão nos parâmetros número grãos abortados por vagem (NAV) e porcentagem de grãos abortados (PGA). UnB, Brasília, DF, 2014

Tabela 3.17. Efeito de diferentes tratamentos de sementes de feijão na produção $(\mathrm{g})$ de grãos por parcela (PG). UnB, Brasília, DF, 2014

Tabela 3.18. Efeito de diferentes tratamentos de sementes de feijão nos parâmetros produtivos, número de grãos por vagem $(\mathrm{NGV})$ e número de grãos por grama (NGG). UnB, Brasília, DF, 2014.

Tabela 3.19. Transmissão planta - semente de Curtobacterium flaccumfaciens pv. flaccumfaciens em plantas de feijoeiro, cultivar Pérola, oriundas de sementes inoculadas. UnB, Brasília, DF, 2014. 


\section{RESUMO}

VILlELA, João Gilberto Alves. Tratamento químico de sementes de feijão (Phaseolus vulgaris L.) para o controle de Curtobacterium flaccumfaciens pv. flaccumfaciens. 2015. 132p. Dissertação (Mestrado em Fitopatologia) - Universidade de Brasília, Brasília, DF.

A Murcha de Curtobacterium, causada pela bactéria Curtobacterium flaccumfaciens pv. flaccumfaciens (Cff), é um importante problema para o cultivo do feijoeiro (Phaseolus vulgaris L.) no Brasil. A principal forma de disseminação da bactéria é por sementes contaminadas. No presente trabalho avaliou-se a eficiência de diferentes tratamentos de sementes no controle da Murcha de Curtobacterium em feijoeiro. Inicialmente se avaliou "in vitro" a sensibilidade de Cff a fungicidas e bactericidas cúpricos, casugamicina, cloretos de benzalcônio e ácido peracético. Os tratamentos de sementes realizados foram: imersão em solução de cobre, casugamicina, cloretos de benzalcônio e ácido peracético, exposição a vapor de etanol e metanol, e ozonização. Na avaliação da eficiência dos tratamentos na erradicação de $C f f$, sementes inoculadas foram tratadas e submetidas ao processo de extração, verificando posteriormente a incidência de sementes contaminadas e número de células bacterianas. Foram realizados experimentos em condições de campo e casa de vegetação. No ensaio em campo foi avaliado o efeito dos tratamentos sobre a qualidade fisiológica das sementes, e em casa de vegetação avaliou-se o efeito dos tratamentos na qualidade fisiológica das sementes, no desenvolvimento vegetativo da planta, na incidência e severidade da Murcha de Curtobacterium, produção de grãos, além da transmissão de Cff via planta - semente. Hidróxido de cobre $(30 \mu \mathrm{g} / \mathrm{mL})$, oxicloreto de cobre $(50 \mu \mathrm{g} / \mathrm{mL})$, óxido cuproso $(20 \mu \mathrm{g} / \mathrm{mL})$, sulfato de cobre $(20 \mu \mathrm{g} / \mathrm{mL})$, casugamicina $(100 \mu \mathrm{g} / \mathrm{mL})$, cloretos de benzalcônio $(20 \mu \mathrm{g} / \mathrm{mL})$ e ácido paracético $(200 \mu \mathrm{g} / \mathrm{mL})$ inibiram o crescimento da Cff "in vitro". Os tratamentos com cloretos de benzalcônio e vapor de metanol foram os mais eficientes na redução da incidência de sementes contaminadas e do número de células bacterianas em sementes de feijão. Em campo os tratamentos com ácido peracético e ozônio reduziram significativamente a emergência e velocidade de emergência das plântulas. Os resultados obtidos em casa de vegetação mostraram que os tratamentos não interfiram na qualidade fisiológica das sementes, e plantas oriundas de sementes inoculadas tratadas ou não, apresentaram menor desenvolvimento vegetativo e produção de grãos. Nenhum tratamento de sementes foi 
eficiente na redução da incidência e severidade da Murcha de Curtobacterium. A taxa de transmissão de $C f f$ das plantas para as sementes foi de aproximadamente $24 \%$.

Palavras-chave: Murcha de Curtobacterium, patologia de sementes, ozônio, produtos fitossanitários, vapor de álcool.

Orientador - Carlos Hidemi Uesugi - UnB. 


\begin{abstract}
VILLELA, João Gilberto Alves. Chemical treatment bean (Phaseolus vulgaris L.) seeds for the control of Curtobacterium flaccumfaciens pv. flaccumfaciens. 2015. 132p. Dissertation (Master in Plant Pathology) - Universidade de Brasilia, Brasilia, DF, Brazil.
\end{abstract}

Bacterial Wilt, caused by Curtobacterium flaccumfaciens pv. flaccumfaciens, is an important disease for bean (Phaseolus vulgaris L.) production in Brazil. Seeds are the major way of spread this bacterium. The objective of this study was to evaluate the efficiency of different seed treatments to control bacterial wilt in bean. First an "in vitro" test was conductive to evaluate the sensitivity of $C f f$ to copper formulations, kasugamycin, benzalkonium chlorides and peracetic acid. The seed treatments performed were: immersion in solution of copper, kasugamycin, benzalkonium chlorides and peracetic acid, exposure to vapor ethanol and methanol, and ozonation. In the evaluation of treatments efficiency in eradicating of $C f f$, inoculated seeds were treated and subjected to extraction process, then checking the incidence of contaminated seeds and number of bacterial cells. Experiments were carried in field conditions and greenhouse conditions. In field experiment was evaluated the effects of treatments on seed physiological quality, and greenhouse was measured the effect of treatments on seed physiological quality, in vegetative plant development, in incidence and severity of bacterial wilt, in production, beyond the transmission of $C f f$ via plant - seed. The products copper hydroxide $(30 \mu \mathrm{g} / \mathrm{mL})$, copper oxychloride $(50 \mu \mathrm{g} / \mathrm{mL})$, cuprous oxide (20 $\mu \mathrm{g} / \mathrm{mL})$, copper sulfate $(20 \mu \mathrm{g} / \mathrm{mL})$, kasugamycin $(100 \mu \mathrm{g} / \mathrm{mL})$, chlorides benzalkonium (20 $\mu \mathrm{g} / \mathrm{mL})$ and peracetic acid $(200 \mu \mathrm{g} / \mathrm{mL})$ inhibited the growth of Cff "in vitro". Treatments with benzalkonium chlorides and vapor methanol were the most effective in reducing the incidence of contaminated seeds and the number of bacterial cells in bean seeds. Under field conditions the treatments with peracetic acid and ozone significantly reduced emergence and seedling emergence speed. The results obtained in the greenhouse showed that the treatments do not interfere in seed physiological quality, and plants grown from seeds inoculated, treated or not, showed lower vegetation development and grain production. The Cff transmission rate of the plants for seeds was approximately $24 \%$. 
Keywords: Bacterial Wilt, seed pathology, ozone, phytosanitary products, vapor of alcohol.

Advisor: Carlos Hidemi Uesugi - UnB. 


\section{INTRODUÇÃO}

O feijoeiro (Phaseolus vulgaris L.) é cultivado por pequenos e grandes produtores, em diversificados sistemas de produção e em todas as regiões brasileiras, possuindo forte apelo social e econômico.

O feijoeiro é uma planta que está sujeita à incidência de um grande número de doenças, causadas por fungos, nematóides, vírus e bactérias, que podem causar quedas significativas em seu rendimento. Entre as doenças bacterianas, a Murcha de Curtobacterium, causada por Curtobacterium flaccumfaciens pv. flaccumfaciens (Hedges) Collins \& Jones, tem sido apontada como uma das doenças emergentes de maior importância para a cultura do feijoeiro (Maringoni \& Camara, 2006; Herbes et al., 2008).

A doença somente foi relatada no Brasil em 1995 por Maringoni \& Rosa (1997), em uma lavoura de feijoeiro no Estado de São Paulo. Posteriormente o patógeno foi constatado em várias localidades produtoras de feijão nos estados de São Paulo (Maringoni, 2002), Paraná e Santa Catarina (Leite Junior et al., 2001), Goiás e no Distrito Federal (Uesugi et al., 2003).

Curtobacterium flaccumfaciens pv. flaccumfaciens (Cff) caracteriza-se por colonizar os vasos xilemáticos, obstruindo a passagem de seiva. Os sintomas da Murcha de Curtobacterium em feijoeiro são o amarelecimento, nanismo, murcha, escurecimento vascular e morte, com a planta podendo não ultrapassar a fase de plântula. Pode haver uma descoloração amarela ou púrpura em sementes infectadas (Saettler, 1991). A bactéria é transmitida por sementes contaminadas externa ou internamente, a partir da infecção sistêmica da planta. Sementes infectadas são o principal meio de disseminação do patógeno a longas distâncias (Hedges, 1926). 
As medidas recomendadas para o controle da Murcha de Curtobacterium são uso de cultivares resistentes, rotação de culturas com espécies não suscetíveis e uso de sementes sadias (Bianchini et al., 2005). Estudos relacionados a tratamento de sementes, visando à erradicação ou diminuição da população de $C f f$ em sementes de feijão são escassos.

Tratamento de sementes, no sentido amplo, envolve a aplicação de diversos processos e substâncias as sementes, com o objetivo de preservar ou aperfeiçoar o desempenho e aumentar a produtividade das plantas. No sentido restrito e mais tradicional, tratamento de sementes visa, exclusivamente, o controle de agentes causais de doenças que interferem na produtividade (Menten, 1995). Entre os métodos de tratamento de sementes descritos na literatura incluem-se métodos físicos, químicos e biológicos (Machado, 2006).

Nesse sentido, objetivou-se, com o presente trabalho, avaliar a eficiência do tratamento químico de sementes no controle da Murcha de Curtobacterium em feijoeiro, bem como verificar o efeito do mesmo sobre a qualidade fisiológica das sementes, no desenvolvimento vegetativo e produção das plantas. 


\section{OBJETIVO GERAL}

- Avaliar a eficiência do tratamento químico de sementes no controle da Murcha de Curtobacterium em feijoeiro.

\section{OBJETIVOS ESPECÍFICOS}

- Avaliar o efeito de diferentes produtos fitossanitários sobre o crescimento de Curtobacterium flaccumfaciens pv. flaccumfaciens "in vitro".

- Avaliar a eficiência de diferentes tratamentos na erradicação de C. flaccumfaciens pv. flaccumfaciens em sementes de feijão.

- Avaliar o efeito de diferentes tratamentos de sementes na emergência e velocidade de emergência de plântulas de feijoeiro em condições de campo e casa de vegetação.

- Avaliar o efeito de diferentes tratamentos de sementes no desenvolvimento vegetativo do feijoeiro.

- Avaliar o efeito de diferentes tratamentos de sementes sobre a incidência e severidade de Murcha de Curtobacterium em plantas de feijoeiro.

- Determinar a produção de grãos em plantas de feijoeiro provenientes de sementes tratadas e não tratadas.

- Determinar a taxa de transmissão planta - semente de C. flaccumfaciens pv. flaccumfaciens em plantas de feijoeiro oriundas de sementes inoculadas. 


\section{REVISÃO DE LITERATURA}

\subsection{Aspectos gerais da cultura do feijoeiro}

O feijoeiro comum (Phaseolus vulgaris L.) é uma das principais culturas produzidas no Brasil e no mundo. Sua importância extrapola o aspecto econômico, por sua relevância enquanto fator de segurança alimentar e nutricional e sua importância cultural na culinária de diversos países e culturas (Barbosa \& Gonzaga, 2012).

De acordo com Santos \& Gavalines (2008), o feijoeiro comum é classificado como pertencente ao Reino Vegetal; Ramo Embryphytae syphonogamae; Sub-ramo Angiospermae; Classe Magnoliopsida (Dicotiledoneae); Sub-classe Archichlamydae; Ordem Rosales; Família Fabaceae (Leguminosae); Subfamília Faboideae (Papilionoideae); Tribo Phaseoleae; Subtribo Phaseolineae; Gênero Phaseolus L. e espécie Phaseolus vulgaris L.

O gênero Phaseolus originou-se nas Américas e possui cerca de 55 espécies, das quais cinco são cultivadas: $P$. vulgaris L. (feijão comum), $P$. lunatus (feijão de lima), $P$. coccineus L. (feijão ayocote), P. acutifolius A. Gray (feijão tepari) e P. polyanthus Greenman. A espécie de maior relevância econômica é o Phaseolus vulgaris, por ser cultivada há mais tempo e a mais utilizada. (Santos \& Gavilanes, 2008; Singh, 2001).

Atualmente, relata-se que o feijoeiro comum teve dois centros principais de domesticação e um terceiro de menor expressão. O primeiro localiza-se na região central das Américas, principalmente México, onde se originou a maioria das cultivares de grãos pequenos como 'Carioca'. O segundo localiza-se no sul dos Andes, principalmente no norte da Argentina e no sul do Peru, onde se originaram os cultivares de sementes grandes, semelhantes a cultivar 'Jalo'. A terceira área de domesticação provavelmente intermediária entre as duas primeiras, situa-se na Colômbia, o que tem sido possível firmar a partir de dados de padrões eletroforéticos de faseolina, a principal proteína de reserva da semente de feijão (Gepts \& Debouck, 1991). 
Apesar de não saber exatamente se o processo de dispersão do feijoeiro comum se deu a partir da Mesoamérica ou partir da América do Sul ou, ainda, a partir das duas regiões de forma independente, sua origem múltipla (não cêntrica) e dentro do continente americano parece inquestionável e apresenta-se como consenso entre os especialistas no assunto, pois a maioria das evidências confirmam essa teoria. O processo de dispersão continuou, sendo levado ao velho mundo pelos europeus, após o descobrimento das Américas, no século XV (Faria et al., 2005).

O feijoeiro comum é uma planta herbácea, anual, autógama, diplóide $(2 n=2 x=22$ cromossomos), com taxa de fecundação cruzada estimada entre 3\% e 5\% (Burle et al., 2010). Em razão de ser cultivado em grande diversidade de ambientes e em muitos países, ele é uma das espécies com maior variabilidade de caracteres agronômicos, como hábito de crescimento, tamanho e cor de grãos e ciclo (Santos \& Gavilanes, 2008).

Uma planta de feijão é composta de partes aparentemente distintas, os órgãos. Há um sistema radicular no solo e, acima deste um caule que porta folhas e ramos. Nas plantas mais velhas, pode-se ter uma visão detalhada das suas partes: raiz, caule ou haste principal, folhas e hastes axilares, inflorescência, fruto e semente (Santos \& Gavilanes, 2006).

O sistema radicular é formado por uma raiz principal, ou primária, da qual se desenvolvem, lateralmente, as raízes secundárias, terciárias e outras. Ademais, os pêlos absorventes estão sempre presentes nas proximidades das regiões de crescimento. Como em muitas leguminosas, na raiz do feijoeiro existem nódulos com bactérias (Rhizobium spp.), quase esféricos e de tamanho variável (Vilhordo et al., 1988). Estudos sobre o sistema radicular do feijoeiro mostram que a maior porcentagem de raízes, 74,5 a 87,4\% do total, esta localizada bem próximo à superfície do solo, $10 \mathrm{~cm}$ de profundidade e quase totalidade, 97,4\%, encontra-se nos primeiros $20 \mathrm{~cm}$ do solo. Em consequência, a planta explora 
essencialmente a camada superficial do solo, sendo por isso muito sensível à falta de umidade (Inforzato \& Miyasaka, 1963).

O caule é herbáceo, classificado morfologicamente como haste, e apresenta, na planta adulta, secção transversal cilíndrica e levemente angulosa (aristado). Ele é o eixo principal da planta, possuindo os nós, que são os pontos de inserção das folhas e dos quais saem os ramos laterais e as inflorescências. Nos nós se encontram três gemas, denominada tríada, que podem ser de três tipos, vegetativo, floral e vegetativo e completamente floral. Em cada nó com uma folha trifoliolada e uma inflorescência, a qual resulta em rácimo com vagens, esse conjunto é denominado de unidade de produção. Os nós caulinares são numerados em sequência ascendente, sendo o primeiro nó aquele onde ocorre a inserção dos cotilédones; o segundo, a inserção das folhas primárias; o terceiro, a primeira folha trifoliolada, e assim sucessivamente. O número de nós no caule principal está relacionado com o tipo de hábito de crescimento, e o rendimento está relacionado com o número de rácimos com vagens por planta (Costa, 2014; Santos \& Gavilanes, 2006).

O hábito de crescimento é considerado um dos caracteres mais importantes, pois é essencial na descrição das cultivares, na escolha das mais adequados para o plantio nas mais variadas condições de cultura e, também, na obtenção de novas cultivares pelo melhoramento (Santos \& Gavilanes, 2006).

As plantas de feijoeiro podem ser de hábito de crescimento determinado ou indeterminado. As plantas de hábito de crescimento determinado são as que desenvolvem uma inflorescência no ápice da haste principal e das hastes laterais, a emissão e a elongação de folhas e ramos cessam por ocasião do advento das flores, possuem número limitado de nós e o florescimento ocorre do ápice para base da planta. O período de floração é curto e a maturação uniforme (Costa, 2014; Santos \& Gavilanes, 2006; Silva, 2014; Portes, 1988). 
Nas plantas de crescimento indeterminado os meristemas apicais da haste principal e das laterais continuam vegetativos durante o florescimento. Portanto as plantas continuam a produzir folhas e flores por um período mais longo do que as determinadas. As inflorescências são axilares, isto é, desenvolvem-se nas axilas das folhas, e a floração inicia-se da base para o ápice da planta (Costa, 2014; Santos \& Gavilanes, 2006; Silva, 2014; Portes, 1988).

O crescimento do caule determina os principais tipos de planta do feijoeiro: arbustivo, prostrado e trepador (Silva, 2014).

Em função das diferentes gradações relativas ao porte, distribuição de flores e vagens, grau e tipo de ramificação, necessidade de tutoramento e desempenho, os hábitos de crescimento podem ser agrupados em quatro tipos principais: Tipo I - hábito de crescimento determinado, arbustivo e porte da planta ereto. Tipo II - hábito de crescimento indeterminado, arbustivo, porte da planta ereto e caule pouco ramificado. Tipo III - hábito de crescimento indeterminado, prostrado ou semiprostrado, com ramificação bem desenvolvida e aberta. Tipo IV - hábito de crescimento indeterminado, trepador; caule com forte dominância apical e número reduzido de ramos laterais, pouco desenvolvidos. Ocorrem hábitos intermediários entre os hábitos indeterminados II / III, e III / IV (Silva, 2014).

O feijoeiro apresenta o fenômeno de heterofilia, pois forma dois tipos de folha durante sua ontogênese: simples e compostas. As simples são duas e são as primeiras (primárias) a serem constituídas. Apresentam filotaxia oposta, de formato cordiforme e são acuminadas. Elas caem antes do completo desenvolvimento da planta. As folhas compostas possuem as seguintes partes: estípulas, pecíolo, raque, pecíolo, pulvínulos e lâmina foliar composta (trifoliolada). O seu tamanho e sua forma variam consideravelmente, de acordo com a cultivar e os fatores ambientais (Santos \& Gavilanes, 2006). 
A flor do feijoeiro é formada pelo cálice e corola. O cálice é verde e a corola composta de cinco pétalas que podem ser brancas, rosadas ou violáceas. O estandarte é a pétala maior e as asas são as duas menores. As outras duas, soldadas uma a outra, formam a quilha. A quilha é retorcida, em forma de espiral, e no seu interior se encontram o androceu e o gineceu, que são os órgãos masculino e feminino, respectivamente. $\mathrm{O}$ androceu é formado de dez estames, sendo nove aderentes pelo filete e um livre. O gineceu é unicarpelar, com ovário estreito e alongado. Os óvulos se encontram, em linha, dentro do ovário. $\mathrm{Na}$ extremidade superior do estilete se encontra o estigma que possui pêlos na face inferior, úteis para reter os grãos de pólen, por ocasião da polinização. As flores do feijoeiro não são isoladas, são agrupadas em uma haste que sustenta os botões florais. Esse conjunto é a inflorescência floral ou rácimo floral (Costa, 2014).

O fruto é tipo legume (vagem), por possuir um só carpelo, seco, deiscente, cuja deiscência ocorre na metade do carpelo (Vilhordo, 1988).

A semente de feijão é exalbuminosa isto é, não possui albume, as reservas nutritivas estão concentradas nos cotilédones. Compõe-se de um tegumento que envolve um embrião bem desenvolvido. Tegumento ou testa, que corresponde à membrana secundina do óvulo, e a capa de proteção da semente onde se localizam os pigmentos. Externamente o tegumento apresenta hilo, micrópila e rafe. Internamente a semente está constituída só por um embrião, o qual é formado pela plúmula, duas folhas primárias, hipocótilo, dois cotilédones e a radícula (Vilhordo, 1988).

A cor do tegumento do grão apresenta ampla variabilidade de cores. O tegumento pode ser de cor uniforme ou possuir mais de uma cor, distribuídas em forma de estrias, pontuações ou manchas. Pode ser de cor brilhante, opaca ou apresentar nuances. As diferenças, das características externas apresentadas pelos grãos são usadas para classificar os 
grãos em tipos comerciais: Preto, Mulatinho, Carioca, Roxinho, Rosinha, Amarelo, Manteigão, Branco, e outros (Costa, 2014; Silva, 2014).

Durante o ciclo de uma planta de feijão ocorrem modificações morfológicas e fisiológicas a partir das quais podem ser identificados os estádios de desenvolvimento da planta. A duração dos estádios é influenciada pelas cultivares e por fatores ambientais. Assim, a utilização da escala de desenvolvimento da planta de feijão oferece maior segurança para orientar ações de manejo na cultura ao invés de basear-se apenas em escala de tempo, ou seja, número de dias (CTSBF, 2012).

A escala de desenvolvimento usual para a planta de feijão compreende dez estádios (Tabela 1.1). A identificação de cada estádio é feita com base em um código com uma letra e um número. A letra corresponde à fase à qual o estádio pertence, isto é, $\mathrm{V}=$ fase vegetativa e $\mathrm{R}$ = fase reprodutiva. Os números de zero a nove indicam, de forma crescente, a posição do estádio na escala (Fernández et al., 1985).

Tabela 1.1. Estádios fenológicos do feijoeiro.

\begin{tabular}{cc}
\hline Estádio $^{(\mathbf{1})}$ & Descrição $^{(\mathbf{2})}$ \\
\hline V0 & Germinação: emissão da radícula e caulículo \\
V1 & Emergência: os cotilédones aparecem ao nível do solo \\
V2 & Folhas primárias expandidas \\
V3 & Primeira folha trifoliolada \\
V4 & Terceira folha trifoliolada \\
R5 & Pré floração: aparecimento do primeiro botão floral e do primeiro rácemo \\
R6 & Floração: abertura da primeira flor \\
R7 & Formação das vagens: aparecimento da primeira vagem \\
R8 & Enchimento das vagens: início do enchimento da primeira vagem \\
R9 & Maturação: as vagens perdem sua pigmentação e começam a secar
\end{tabular}

(1) V = Vegetativa; R = Reprodutiva; (2) Cada estádio começa quando 50\% das plantas apresentam as condições relativas ao estádio. Fonte: Adaptado de Fernández et al., (1985). 
O feijoeiro é uma planta $C_{3}$, portanto seu mecanismo de carboxilação é chamado de processo redutivo da pentose fosfato (ou ciclo de Calvin ou ciclo de Benson-Calvin). É através deste mecanismo que os feijoeiros fixam o $\mathrm{CO}_{2}$ atmosférico, metabolizando-o em compostos orgânicos que, em última instância vão formar a estrutura das plantas. Esta estrutura é formada em mais de $90 \%$ por compostos de carbono e em menos de $10 \%$ por elementos minerais (Portes, 1988).

Apesar de sua ampla distribuição geográfica, o feijoeiro é muito pouco tolerante a fatores extremos de ambiente, sendo uma cultura relativamente exigente no que diz respeito à maioria das condições edafoclimáticas (Andrade et al., 2008).

A temperatura média ideal para a cultura do feijão corresponde a $21^{\circ} \mathrm{C}$, sendo consideradas aptas para o seu cultivo aquelas que apresentam valores médios de temperaturas entre 15 a $29,5^{\circ} \mathrm{C}$ (Dourado Neto \& Fancelli, 2000).

A ocorrência de temperaturas acima ou abaixo da faixa ótima, dependendo da frequência e da duração, pode ocasionar sérios prejuízos ao estabelecimento, crescimento e desenvolvimento da cultura, resultando em baixo rendimento de grãos.

Se baixas temperaturas ocorrem imediatamente após a semeadura, podem impedir, reduzir ou atrasar a germinação das sementes e a emergência das plântulas, resultando possivelmente, baixa população de plantas. Durante o crescimento vegetativo, baixas temperaturas reduzem a altura da planta e o crescimento de ramos, conduzindo à produção de pequeno número de vagens por planta (Andrade et al., 2008).

Alta temperatura talvez seja o fator climático que exerce maior influência sobre as estruturas reprodutivas, vingamento e retenção de vagens no feijoeiro. A interação pólen/estigma, a germinação do grão de pólen, o crescimento do tubo polínico e a fertilização são todos afetados pelas altas temperaturas. $\mathrm{O}$ abortamento de botões florais, flores e vagens é 
aumentado quando temperaturas entre 30 e $40^{\circ} \mathrm{C}$ coincidem com o período reprodutivo do feijoeiro (Andrade et al., 2008; Didonet, 2003).

Por ser uma planta $C_{3}$ o feijoeiro satura-se fotossinteticamente a intensidade de luz relativamente baixas. De forma geral, pode-se citar que regiões que apresentem valores de radiação solar em torno de $150-250 \mathrm{~W} / \mathrm{m}^{2}$ podem ser consideradas como ideais para o desenvolvimento do feijoeiro. Acima de $400 \mathrm{w} / \mathrm{m}^{2}$ a taxa de fotossíntese é praticamente constante. Quanto à resposta ao comprimento do dia, atualmente, as cultivares de feijoeiro existentes podem ser consideradas insensíveis ao fotoperíodo (Barbosa \& Gonzaga, 2012; Portes, 1988).

Com relação à água, o feijoeiro é considerado como sendo uma espécie pouco tolerante a deficiências hídricas. A cultura do feijão exige um mínimo de $300 \mathrm{~mm}$ de precipitação para que produza a contento, sem a necessidade da pratica de irrigação. Regiões cujas precipitações oscilem entre 250 e $500 \mathrm{~mm}$ anuais são consideradas aptas para a implantação da mencionada espécie, embora tal limitação encontra-se mais diretamente condicionada à distribuição do que à quantidade total de chuvas ocorrida no período (Dourado Neto \& Fancelli, 2000).

Cultivado por pequenos e grandes produtores, em diversificados sistemas de produção e em todas as regiões brasileiras, o feijoeiro comum reveste-se de grande importância econômica e social. Dependendo da cultivar e da temperatura ambiente, pode apresentar ciclos variando de 65 a 100 dias, o que o torna uma cultura apropriada para compor, desde sistemas agrícolas intensivos irrigados, altamente tecnificados, até aqueles com baixo uso tecnológico, principalmente de subsistência (Aidar, 2003).

O plantio de feijão no Brasil é feito ao longo do ano, concentrando-se em três épocas ou safras. Dadas às características da cultura, a forma como o feijão é cultivado nas diferentes regiões do país, e, a diversidade climática do Brasil, em qualquer mês, sempre haverá 
produção em algum ponto do país, o que contribui para manter o abastecimento interno e reduzir a oscilação dos preços (Barbosa \& Gonzaga, 2012).

A produção apresenta certa sazonalidade que se traduz em três safras não muito bem definidas no tempo. A $1^{\text {a }}$ safra ou "safra das águas" (também chamada de "safra do Sul e Sudeste") é colhida a partir de novembro até março, com maior intensidade em dezembro; a semeadura geralmente é feita entre agosto e outubro, podendo se estender até novembro e dezembro. A $2^{\text {a }}$ safra ou "safra da seca" ou "safrinha" (também chamada de "safra do Nordeste e Sudeste") é colhida de abril-maio até junho-julho; nesse caso, a semeadura é feita entre janeiro e abril. A $3^{\mathrm{a}}$ safra também é conhecida como "safra de outono-inverno", "safra do Sudeste" e "safra irrigada"; a semeadura é feita a partir de maio, com a colheita entre agosto e outubro (Barbosa \& Gonzaga, 2012).

O cultivo de feijoeiro é bastante difundido em todo o território nacional, no sistema solteiro ou consorciado com outras culturas (Barbosa \& Gonzaga, 2012).

O feijoeiro pode ser cultivado tanto em várzeas quanto em terras altas, desde que em locais com solos soltos, friáveis e não sujeitos ao encharcamento. O manejo adequado do solo é muito importante para a garantia de condições ótimas ao desenvolvimento do feijoeiro comum, sobretudo do seu sistema radicular. A cultura se estabelece bem em plantio convencional, cultivo mínimo e plantio direto, desde que se tomem os cuidados inerentes a cada sistema de manejo (CTSBF, 2012).

O uso de sistemas conservacionistas de manejo do solo, que reduzem a mobilização e mantêm mais cobertura no solo, trazem benefícios à cultura do feijão, pois além de reduzir a erosão, mantêm a temperatura do solo mais constante, aumentando o armazenamento de água e a eficiência dos fertilizantes em geral. O plantio direto, consagrado como o sistema de manejo mais eficiente no controle da erosão hídrica do solo, deverá ser adotado sempre que possível. No plantio direto, deve ser adotado um sistema de rotação de culturas, no qual o 
feijão deve ser precedido por um cultivo com grande produção de biomassa, de forma a manter a cobertura do solo e proteger a sua superfície contra o impacto das gotas da chuva, além de servir como obstáculo ao escoamento de água e impedir que as vagens toquem diretamente o solo, melhorando a qualidade dos grãos. O uso de corretivos da acidez do solo, como o calcário, e de fertilizantes orgânicos ou minerais, em quantidades baseadas na análise de solo e nas necessidades do feijão, também contribuem para a conservação e a fertilidade do solo e o aumento e/ou manutenção da produtividade da cultura (CTSBF, 2012).

A utilização correta do espaçamento e da densidade de plantio na cultura do feijão é prática cultural de baixo custo e de fácil entendimento e adoção pelos agricultores. A distribuição adequada de plantas tem efeito sobre o controle de plantas daninhas e pode representar uma estratégia importante para a utilização mais eficiente de alguns fatores de produção, como luz, água e nutrientes (Araújo \& Ferreira, 2008).

De modo geral, o espaçamento em lavouras comerciais de produção de grãos de feijão varia de 0,3 a $0,6 \mathrm{~m}$ entre fileiras. Sendo os espaçamentos menores para cultivares de ciclo mais precoce e hábitos de crescimento tipos I e II e os espaçamentos maiores para cultivares de ciclo normal e hábito de crescimento indeterminado (tipo II e III). Os espaçamentos de 0,4 e $0,5 \mathrm{~m}$ são os mais convenientes. O espaçamento de $0,3 \mathrm{~m}$ não deve ser utilizado quando for previsto controle mecânico de plantas daninhas. Já o espaçamento de 0,6m só deve ser adotado em solos de alta fertilidade. Na semeadura as sementes devem ser uniformemente distribuídas e, na regulagem da semeadora, deve-se considerar o seu poder germinativo. As populações de plantas indicadas variam em função do hábito de crescimento das plantas e da cultivar (CTSBF, 2012).

A profundidade de semeadura pode gerar desuniformidade na emergência e o tombamento de plântulas, além de propiciar ambiente favorável à proliferação e ao ataque de fungos do solo. A recomendação geral é utilizar 3 a $4 \mathrm{~cm}$ de profundidade em solos argilosos 
ou úmidos e 5 a $6 \mathrm{~cm}$ em solos arenosos. Em plantio realizado com solo frio, deve-se optar por profundidade de 3 a 4 cm (Araújo \& Ferreira, 2008; CTSBF, 2012).

Para a cultura do feijoeiro, o estabelecimento rápido e uniforme das plantas no solo é de fundamental importância para sucesso da lavoura, onde o uso de sementes de alta qualidade é imprescindível. Porém, na maioria das semeaduras realizadas atualmente, os produtores não conhecem a qualidade fisiológica e sanitária fisiológico das sementes utilizadas, pois a cultura possui uma baixa taxa de utilização de sementes, ficando ao redor de 19\% no Brasil e $26 \%$ no Distrito Federal (ABRASEM, 2014).

Uma semente de qualidade deve ter: 1) pureza genética, que irá expressar-se no potencial produtivo, nas suas características agronômicas, na reação a doenças e pragas, nas características da semente, entre outras; 2) pureza física, determinada pelo grau e tipo de contaminantes presentes no lote; 3) qualidade fisiológica, evidenciada pelo seu potencial em gerar uma nova planta, perfeita e vigorosa, sob condições favoráveis; e 4) bom estado fitossanitário, pois a boa semente não deve veicular patógenos, capazes de afeta negativamente, a emergência e o vigor das plântulas e constituir o inóculo primário para o desenvolvimento de epidemias consequente redução no rendimento (Abreu, 2005).

Assim, é necessário que, no momento de adquirir sementes para a formação da lavoura, o produtor conheça a procedência da mesma, sendo recomendável que, além da análise da sua qualidade física e fisiológica, seja também exigido o boletim de análise sanitária (Silva, 2005).

No país há boa disponibilidade de cultivares melhoradas e adaptadas para as diferentes regiões, o que facilita o desenvolvimento da cultura. Entretanto, a falta de sementes na quantidade demandada, constitui sério problema para o setor. Outro aspecto que restringe o desenvolvimento dessa cadeia é a grande variedade de tipos e classes de feijões produzidos e 
comercializados regionalmente, o que dificulta a padronização, a classificação do produto e a consequente formação de preços no mercado (Barbosa \& Gonzaga, 2012).

\subsection{Aspectos econômicos da cultura do feijoeiro}

O feijoeiro comum é, historicamente, um dos principais alimentos consumidos no Brasil e no mundo. O feijão constitui-se em uma das mais importantes fontes protéicas na dieta humana em países em desenvolvimento das regiões tropicais e subtropicais. Em 2007, o

maior consumo desse produto ocorria nas Américas (40,8\%), seguindo-se a Ásia (37,8\%), a África $(17,8 \%)$, a Europa $(3,3 \%)$ e a Oceania $(0,1 \%)$. Os países em desenvolvimento são responsáveis por $87,1 \%$ do consumo mundial (Barbosa \& Gonzaga, 2012).

Considerando todos os gêneros e espécies de feijão englobados nas estatísticas da FAO, publicadas em 2013, a produção mundial de feijão (124 países), situou-se em torno de 23,14 milhões de toneladas, ocupando uma área de 29,23 milhões de hectares. Entre os continentes, a Ásia foi o maior produtor mundial (46\%), seguido das Américas (30,6\%), da África $(21,0 \%)$, da Europa $(2,2 \%)$ e da Oceania $(0,2 \%)$.

Mais da metade $(54,7 \%)$ da produção mundial origina-se de apenas quatro países. Índia e Myanmar são os principais produtores mundiais de feijão. Em 2013 o Myanmar ocupou a primeira posição, com produção de 3,8 milhões de toneladas, em uma área de 9,1 milhões de hectares. Outros importantes produtores de feijão são: Brasil, China, México e Estados Unidos (FAOSTAT, 2014).

Fundamental para a segurança alimentar e nutricional, sobretudo para classes mais carentes da população, o feijoeiro comum representa uma dos pilares da dieta brasileira. Atualmente o consumo per capita situa-se na ordem de $16,7 \mathrm{~kg} / \mathrm{habitante} / \mathrm{ano}$. Diversos aspectos culturais determinam grandes variações regionais quanto ao gosto e preferência por tipos de grãos consumidos (IBGE, 2014). 
A maior parte do feijão produzido no Brasil vem da agricultura familiar, que é responsável por cerca de $60 \%$ da produção nacional. Por isso o setor não é muito especializado. Os grandes produtores optam por produzir a leguminosa como uma aposta de curto prazo (os três meses entre o plantio e a colheita) em meio a suas atividades principais. E isso acontece somente quando os preços estão em patamares elevados, pois assim conseguem reforçar suas receitas (CTSBF, 2012).

Segundo o Levantamento de Safra - Grãos (CONAB, 2014), na safra 2012/2013 o país produziu 2,8 milhões de toneladas em 3,07 milhões de hectares, com uma produtividade média de $913 \mathrm{~kg} / \mathrm{ha}$. A primeira safra produziu 0,97 milhões de toneladas em 1,12 milhões de hectares $(858 \mathrm{~kg} / \mathrm{ha})$, a segunda safra produziu 1,1 milhões de toneladas em 1,3 milhões de hectares $(851 \mathrm{~kg} / \mathrm{ha})$ e a terceira safra produziu 0,73 milhões de toneladas em 0,65 milhões de hectares (1131 kg/ha). O Estado do Paraná é o principal produtor, o Distrito Federal ocupa a décima sexta posição. Paraná e Minas Gerais participaram na safra de 2012/2013 por 41,9\% do total do feijão produzido no País. Os dez estados maiores produtores, são responsáveis por $86 \%$ da produção brasileira de feijão. Em termos de produtividade, o Estado de Goiás é o que obteve os melhores resultados nas safras de 2008/2009 a 2012/2013, com rendimentos superiores a $2000 \mathrm{~kg} / \mathrm{ha}$.

A média de produtividade de feijão no Brasil, e considerada baixa, entretanto alguns estados, essa média é superior a $1000 \mathrm{~kg} / \mathrm{ha}$ (Tabelas 1.3 e 1.4), e os agricultores brasileiros que utilizam alta tecnologia já ultrapassam a marca de 3000 kg/ha (Borém \& Carneiro, 2008; CONAB, 2014).

Grandes áreas de cultivo utilizam maquinário moderno e semeadura direta, adotandose elevado nível tecnológico para alcançar alta produtividade de grãos, como é observado na região Centro-Oeste do país, onde se atingiu uma produtividade de $1636,8 \mathrm{Kg} / \mathrm{ha}$ na safra 2012/2013 (Tabela 1.4). Na 3a safra, onde predomina o uso de sistemas agrícolas intensivos, 
irrigados e altamente tecnificados a produtividade nas regiões Centro-Oeste e Sudeste na safra 2012/2013 foram de 2512 e $2517 \mathrm{Kg} /$ ha respectivamente. (CONAB, 2014).

Ressaltando que o feijão, na sua maioria, ainda é produzido por pequenos agricultores, com poucos recursos tecnológicos e que, frequentemente, consorciam essa leguminosa com outras culturas, sobretudo milho (Zea mays L.). Esses agricultores geralmente usam sementes de baixa qualidade, utilizam cultivares inadequadas, adubam mal e não controlam pragas e doenças. Escassez ou má distribuição de chuvas são fatores que contribuem para esse baixo rendimento médio, pois a irrigação não é pratica comum entre esses produtores (Borém \& Carneiro, 2008).

No Brasil, $63 \%$ do volume produzido é de feijão-cores, enquanto $18 \%$ é de feijãopreto e 19\%, de macaçar (caupi). O feijão carioca está distribuído de forma uniforme nas três safras anuais, o feijão-preto concentra-se no Sul do País e aproximadamente $70 \%$ de sua produção origina-se da primeira safra. A variedade macaçar, cultivada na Região Nordeste, concentra-se na segunda safra, à exceção da produção no estado da Bahia (CTSBF, 2012).

Apesar dos atuais 2,9 milhões de toneladas de feijão produzidos o Brasil importou em média, 223 mil toneladas/ano entre os anos de 2008 a 2013 (Tabelas 1.5).

No que tange a importação, a grande maioria é do tipo feijão preto, porém, ocorre importação relevante de feijão de cor e de outros tipos de feijões. Os principais países que exportam para o Brasil são: China, Argentina, Bolívia, Estados Unidos e Bélgica (Barbosa \& Gonzaga, 2012; Ferreira et al., 2008).

O sistema de comercialização do feijão é o mais variado possível, com predomínio de um pequeno grupo de atacadistas que concentra a distribuição da produção, gerando, muitas vezes, especulações quando ocorrem problemas na produção. As características do mercado do produto, sobretudo no que concerne a concentração dos grupos atacadistas, influi diretamente na formação do preço pago ao produtor (Barbosa \& Gonzaga, 2012). 
Tabela 1.2. Área colhida, produção e rendimento de feijão nos principais países produtores (2010 - 2013).

\begin{tabular}{|c|c|c|c|c|c|c|c|c|c|c|c|c|}
\hline \multirow[b]{2}{*}{ País } & \multicolumn{3}{|c|}{2010} & \multicolumn{3}{|c|}{2011} & \multicolumn{3}{|c|}{2012} & \multicolumn{3}{|c|}{2013} \\
\hline & $\begin{array}{c}\text { Área } \\
\text { (mil ha) }\end{array}$ & $\begin{array}{c}\text { Produção } \\
\text { (mil t) }\end{array}$ & $\begin{array}{c}\text { Prod. } \\
\text { (Kg/ha) }\end{array}$ & $\begin{array}{c}\text { Área } \\
\text { (mil ha) }\end{array}$ & $\begin{array}{c}\text { Produção } \\
(\text { mil t })\end{array}$ & $\begin{array}{c}\text { Prod. } \\
\text { (Kg/ha) }\end{array}$ & $\begin{array}{c}\text { Área } \\
\text { (mil ha) }\end{array}$ & $\begin{array}{c}\text { Produção } \\
(\text { mil t })\end{array}$ & $\begin{array}{c}\text { Prod. } \\
\text { (Kg/ha) }\end{array}$ & $\begin{array}{c}\text { Área } \\
\text { (mil ha) }\end{array}$ & $\begin{array}{c}\text { Produção } \\
(\text { mil t })\end{array}$ & $\begin{array}{c}\text { Prod. } \\
\text { (Kg/ha) }\end{array}$ \\
\hline Índia & 11000 & 4890 & 444,5 & 11000 & 4330 & 393,6 & 9100 & 3710 & 407,7 & 9100 & 3630 & 398,9 \\
\hline Myanmar & 2710 & 3530 & 1302,6 & 2712 & 3750 & 1382,7 & 2750 & 3900 & 1418,2 & 2700 & 3800 & 1407,4 \\
\hline Brasil & 3424 & 3159 & 922,6 & 3673 & 3435 & 935,2 & 2709 & 2795 & 1031,7 & 2831 & 2936 & 1037,1 \\
\hline $\begin{array}{l}\text { Estados } \\
\text { Unidos }\end{array}$ & 746 & 1442 & 1933,0 & 476 & 902 & 1895,0 & 684 & 1448 & 2117,0 & 530 & 1111 & 2096,2 \\
\hline China & 911 & 1339 & 1469,8 & 914 & 1583 & 1731,9 & 971 & 1561 & 1607,6 & 930 & 1410 & 1516,1 \\
\hline México & 1630 & 1156 & 709,2 & 895 & 568 & 634,6 & 1559 & 1081 & 693,4 & 1754 & 1295 & 738,3 \\
\hline Tanzânia & 1209 & 867 & 717,1 & 738 & 676 & 916,0 & 1330 & 1199 & 901,5 & 1300 & 1150 & 884,6 \\
\hline Uganda & 952 & 463 & 486,3 & 983 & 447 & 454,7 & 1060 & 425 & 400,9 & 1100 & 461 & 419,1 \\
\hline Quênia & 689 & 391 & 567,5 & 1037 & 578 & 557,4 & 1059 & 614 & 579,8 & 1000 & 529 & 529,0 \\
\hline Camarões & 286 & 354 & 1237,8 & 296 & 365 & 1233,1 & 217 & 343 & 1580,6 & 262 & 352 & 1343,5 \\
\hline T. Mundial & 30808 & 23816 & 773,0 & 30417 & 23211 & 763,1 & 29318105 & 23917 & 1580,6 & 29234 & 23139 & 791,5 \\
\hline
\end{tabular}

Fonte: FAOSTAT, 2014. 
Tabela 1.3. Área colhida, produção e produtividade de feijão nos Estados maiores produtores (2008/2009 - 2012/2013).

\begin{tabular}{|c|c|c|c|c|c|c|c|c|c|c|c|c|c|c|c|}
\hline \multirow{2}{*}{ Estado } & \multicolumn{5}{|c|}{ Área colhida (mil ha) } & \multicolumn{5}{|c|}{ Produção (mil t) } & \multicolumn{5}{|c|}{ Produtividade (Kg/ha) } \\
\hline & $2008 / 09$ & $2009 / 10$ & 2010/11 & 2011/12 & $2012 / 13$ & $2008 / 09$ & 2009/10 & $2010 / 11$ & 2011/12 & $2012 / 13$ & $2008 / 09$ & $2009 / 10$ & 2010/11 & 2011/12 & $2012 / 13$ \\
\hline PR & 630,4 & 521,1 & 522,8 & 481,4 & 480,0 & 723,2 & 794,2 & 821,2 & 677,9 & 658,4 & 1147,2 & 1524,1 & 1570,8 & 1408,2 & 1371,7 \\
\hline MG & 420,7 & 419,6 & 401,3 & 422,3 & 419,7 & 599,3 & 623,7 & 582,3 & 663,7 & 564,8 & 1424,5 & 1486,4 & 1451,0 & 1571,6 & 1345,7 \\
\hline MT & 134,70 & 103,80 & 208,20 & 180,80 & 211,70 & 151,20 & 120,90 & 234,80 & 224,40 & 294,5 & 1122,5 & 1164,7 & 1127,8 & 1241,2 & 1391,1 \\
\hline GO & 114,4 & 113,0 & 109,9 & 126,2 & 108,1 & 263,8 & 288,8 & 260,1 & 308,1 & 236,1 & 2305,9 & 2555,8 & 2366,7 & 2441,4 & 2184,1 \\
\hline SP & 186,3 & 180,6 & 167,0 & 163,8 & 120,1 & 324,8 & 318,6 & 348,0 & 330,9 & 235,6 & 1743,4 & 1764,1 & 2083,8 & 2020,1 & 1961,7 \\
\hline BA & 550,8 & 612,0 & 563,1 & 427,3 & 456,0 & 336,4 & 390,4 & 262,9 & 117,6 & 189,2 & 610,7 & 637,9 & 466,9 & 275,2 & 414,9 \\
\hline $\mathrm{SC}$ & 129,1 & 110,2 & 104,0 & 86,8 & 76,7 & 178,5 & 167,7 & 160,5 & 117,3 & 124,7 & 1382,6 & 1521,8 & 1543,3 & 1351,4 & 1625,8 \\
\hline $\mathrm{RS}$ & 117,0 & 106,7 & 92,4 & 81,3 & 71,2 & 125,4 & 115,3 & 123,9 & 94,1 & 94,7 & 1071,8 & 1080,6 & 1340,9 & 1157,4 & 1330,1 \\
\hline $\mathrm{CE}$ & 589,1 & 458,2 & 612,9 & 433,6 & 341,1 & 159,3 & 84,5 & 259,6 & 32,9 & 66,2 & 270,4 & 184,4 & 423,6 & 75,9 & 194,1 \\
\hline $\mathrm{PE}$ & 316,7 & 264,6 & 322,4 & 229,7 & 176,4 & 136,7 & 88,5 & 161,5 & 33,8 & 46,3 & 431,6 & 334,5 & 500,9 & 147,1 & 262,5 \\
\hline Brasil & 4147,8 & 3608,8 & 3990,0 & 3262,1 & 3075,3 & 3502,7 & 3322,5 & 3732,8 & 2918,4 & 2806,3 & 844,5 & 920,7 & 935,5 & 894,6 & 912,5 \\
\hline
\end{tabular}

Fonte: CONAB, 2014. 
Tabela 1.4. Produção, área plantada e rendimento nacional e por região geográfica nas safras 2011/2012 e 2012/2013.

\begin{tabular}{|c|c|c|c|c|c|c|}
\hline \multirow[t]{2}{*}{ Região } & $\begin{array}{c}\text { Área } \\
\text { (mil ha) }\end{array}$ & $\begin{array}{c}\text { Produção } \\
\text { (mil t) }\end{array}$ & Prod. (Kg/ha) & $\begin{array}{c}\text { Área } \\
\text { (mil ha) }\end{array}$ & $\begin{array}{c}\text { Produção } \\
\text { (mil t) }\end{array}$ & Prod. (Kg/ha) \\
\hline & \multicolumn{3}{|c|}{ 2011/2012 } & \multicolumn{3}{|c|}{$2012 / 2013$} \\
\hline Sul & 649,5 & 889,3 & 1369,2 & 627,9 & 877,8 & 1398,0 \\
\hline Sudeste & 608,1 & 1012,8 & 1665,5 & 558,3 & 815,8 & 1461,2 \\
\hline Nordeste & 1503,9 & 289,3 & 192,4 & 1399,8 & 425,3 & 303,8 \\
\hline Centro-Oeste & 342,1 & 603,0 & 1762,6 & 356,0 & 582,7 & 1636,8 \\
\hline Norte & 158,5 & 124,0 & 782,3 & 133,3 & 104,7 & 785,4 \\
\hline Norte/Nordeste & 1662,4 & 413,3 & 248,6 & 1533,1 & 530,0 & 345,7 \\
\hline Centro-Sul & 1599,7 & 2505,1 & 1566,0 & 1542,2 & 2276,3 & 1476,0 \\
\hline Brasil & 3262,1 & 2918,4 & 894,6 & 3075,3 & 2806,3 & 912,5 \\
\hline
\end{tabular}

Fonte: CONAB, 2014.

Tabela 1.5. Balanço da oferta e demanda de feijão no Brasil (1.000 toneladas), 2008/2009 a $2012 / 2013$.

\begin{tabular}{cccccccc}
\hline Safra & $\begin{array}{c}\text { Estoque } \\
\text { inicial }\end{array}$ & Produção & Importação & Suprimento & Consumo & Exportação & $\begin{array}{c}\text { Estoque } \\
\text { final }\end{array}$ \\
\hline $2008 / 2009$ & 230,0 & 3502,7 & 110,0 & 3842,7 & 3500 & 25,00 & 317,7 \\
$2009 / 2010$ & 317,7 & 3322,5 & 181,2 & 3821,4 & 3450 & 4,5 & 366,9 \\
$2010 / 2011$ & 366,9 & 3732,8 & 207,1 & 4306,8 & 3600 & 20,4 & 686,4 \\
$2011 / 2012$ & 686,4 & 2918,4 & 312,3 & 3917,1 & 3500 & 43,3 & 373,8 \\
$2012 / 2013$ & 373,8 & 2806,3 & 304,4 & 3484,5 & 3320 & 35,3 & 129,2 \\
\hline
\end{tabular}

Fonte: CONAB, 2014. 


\subsection{Doenças do feijoeiro}

O feijoeiro comum (Phaseolus vulgaris L.) é cultivado durante todo o ano, numa grande diversidade de ecossistemas, o que faz com que inúmeros fatores tornem-se limitantes para a sua produção. Entre estes fatores, um dos principais são as doenças as quais, além de diminuírem a produtividade da cultura, depreciam a qualidade do produto (Sartorato et al., 2003).

Segundo Maffia et al., (1988), aproximadamente 108 fungos, 24 nematóides, 19 vírus e 17 bactérias são citados como patógenos do feijoeiro. No Brasil mais de 20 doenças de origem biótica afetam a cultura do feijoeiro durante todo seu ciclo (Lobo Júnior, 2005).

As doenças fúngicas estão divididas em dois grupos com base na sua origem. Assim, temos as doenças denominadas da parte aérea e cujos agentes causais não sobrevivem no solo e, as doenças de solo, cujos agentes causais encontram-se adaptados para sobreviverem neste ambiente. Entre as principais doenças fúngicas, da parte aérea do feijoeiro comum encontramse a Antracnose (Colletotrichum lindemuthianum (Sacc. \& Magnus) Briosi \& Cavara), a Mancha Angular (Pseudocercospora griseola (Sacc.) Crous \& U. Braun), a Ferrugem (Uromyces appendiculatus F. Strauss), o Oídio (Erysiphe polygoni DC.) e a Mancha de Alternária (Alternaria spp.) além de duas outras recentemente identificadas nesta cultura e denominadas de Sarna (Colletotrichum truncatum (Schwein.) Andrus \& W.D. Moore e Carvão (Ustilago sp.) (Lobo Júnior, 2005; Sartorato et al., 2003; Bianchini et al., 2005).

Entre as principais doenças cujos agentes causais apresentam capacidade de sobreviver no solo durante vários anos, em estruturas de sobrevivência, e atacam o sistema radicular ou até mesmo a parte aérea das plantas, formando lesões que restringem o desenvolvimento das mesmas ou causam a sua morte encontram-se o Mofo Branco (Sclerotinia sclerotiorum (Lib.) de Bary), Podridão do Colo (Sclerotium rolfsii Sacc.) a Mela (Thanatephorus cucumeris (A.B. Frank) Donk), a Podridão Radicular de Rhizoctonia (Rhizoctonia solani J.G. Kühn), Podridão 
Radicular Seca (Fusarium solani f. sp. phaseoli W.C. Snyder \& H.N. Hansen), a Murcha de Fusarium (Fusarium oxysporum f.sp. phaseoli J.B. Kendr. \& W.C. Snyder e a Podridão Cinzenta do Caule (Macrophomina phaseolina (Tassi) Goid.) (Lobo Júnior, 2005; Sartorato et al., 2003; Bianchini et al., 2005).

No Brasil, foram descritas mais de dez viroses em feijoeiro (Bianchini et al., 2005). Entre os vírus mais importantes, destaca-se o BCMV (Bean common mosaic virus), causador do Mosaico Comum, BGMV (Bean golden mosaic virus), causador do Mosaico Dourado, BRMV (Bean rugose mosaic virus), agente do Mosaico Rugoso, CpMMV (Cowpea mild mottle virus), agente do Mosaico Angular Amarelo, e SBMV (Southern bean mosaic virus), causador do Mosaico do Sul ou Meridional (Fiallos, 2010). Infecções mistas ocorrem principalmente na safra da seca, quando se observa maior incidência do BGMV. Os danos provocados nestes casos são mais severos que aqueles causados pelas infecções individuais por qualquer um dos vírus. Outro fator agravante é que nas cultivares com resistência ao BGMV, a mesma é perdida quando ocorre a infecção mista do BGMV com vírus isométricos de outros gêneros (Bianchini et al., 2005).

Entre as diversas associações de nematóides ao sistema radicular do feijoeiro, registram os formadores de galhas (Meloidogyne spp.), o nematóide reniforme (Rotylenchulus reniformis), o nematóide das lesões radiculares (Pratylenchus brachyurus) e o nematóide espiralado (Helicotylenchus dihystera) (Bofim Júnior, 2013; Paula Junior \& Zambolim, 2006).

No Brasil, as bacterioses registradas na cultura do feijoeiro são: Crestamento Bacteriano (Xanthomonas axonopodis pv. phaseoli) (Robbs, 1954); Crestamento Bacteriano Aureolado (Pseudomonas savastanoi pv. phaseolicola) (Costa e Paradela, 1972); Fogo Selvagem (P. syringae pv. tabaci) (Ribeiro et al., 1979) e Murcha de Curtobacterium (Curtobacterium flaccumfaciens pv. flaccumfaciens) (Maringoni \& Rosa, 1997). 
Com exceção da Ferrugem, do Oídio e do Mosaico Dourado todas as doenças, com maior ou menor intensidade, são transmitidas pelas sementes. De um modo geral, as doenças de origem fúngica e bacteriana podem ser disseminadas, à longa distância através das sementes infectadas e as doenças fúngicas, também através das correntes aéreas. A curta distância, estas doenças são disseminadas pelas sementes infectadas, vento, chuvas, insetos, animais, partículas de solo aderidas aos implementos agrícolas, água de irrigação e pelo movimento do homem. O vírus do Mosaico Comum é transmitido pelas sementes e por afídeos enquanto que o vírus do Mosaico Dourado é transmitido pela mosca branca (Bemisia tabaci Gennadius) (Sartorato et. al., 2003).

A incidência, a intensidade dessas doenças e os prejuízos causados variam de acordo com a região, a época de plantio, o sistema de plantio, a variedade, a qualidade sanitária da semente e as condições climáticas (Rosolem \& Marubayashi,1994).

Desse modo, o controle de doenças do feijoeiro deve ser integrado visando atingir vários agentes patogênicos, utilizando-se dos princípios de controle de doenças de plantas, exclusão, erradicação, proteção, resistência, terapia e evasão.

No dia 17 de junho de 2014, foi publicado no Diário Oficial da União a Instrução Normativa $\mathrm{n}^{\mathrm{o}} 15$, a qual estabelece o vazio sanitário, para a cultura do feijoeiro comum nos estados de Minas Gerais e Goiás e no Distrito Federal. O objetivo é o controle do vírus (BGMV) causador do Mosaico Dourado e do seu vetor, a mosca branca (B. tabaci). O período de vazio sanitário obrigatório será de 5 de setembro a 5 de outubro de cada ano na área denominada Região 1, em determinados municípios de Goiás, e entre os dias 20 de setembro e 20 de outubro de cada ano, no Distrito Federal, em determinados municípios no Estado de Minas Gerais, e na denominada Região 2, no Estado de Goiás (BRASIL, 2014). 


\subsection{Murcha de Curtobacterium}

A Murcha de Curtobacterium foi relatada pela primeira vez nos Estados Unidos da América, no estado de Dakota do Sul, por Hedges, em 1922, causando perdas de aproximadamente $90 \%$ na produtividade das plantas de feijoeiro afetadas. Nos anos seguintes, a doença foi descrita em outras localidades, como os estados norte-americanos de Michigan, Virgínia, Maryland, Montana e no Distrito de Colúmbia, além de outros países, como Alemanha e França (Hedges, 1926). Na ocasião da descrição em 1922 (Hedges), foi denominada como Bacterium flaccumfaciens tendo recebido posteriormente as seguintes denominações: Phytomonas flaccumfaciens (Hedges, 1922) Bergey et al., 1923, Pseudomonas flaccumfaciens (Hedges, 1922) Stevens 1925; Corynebacterium flaccumfaciens (Hedges, 1922) Downson 1942; Corynebacterium flaccumfaciens pv. flaccumfaciens (Hedges, 1922) Dowson 1942; Corynebacterium flaccumfaciens subsp. flaccumfaciens (Hedges, 1922) Downson 1942 e, finalmente baseado em perfil de proteínas celulares através de eletroforese em gel de poliacrilamida, foi reclassificada como Curtobacterium flaccumfaciens pv. flaccumfaciens (Hedges, 1922), Collins e Jones, 1983 (Carlson \& Vidaver, 1982; Collins e Jones, 1983; Young et al., 1996).

A bactéria causadora da Murcha de Curtobacterium do feijoeiro, C. flaccumfaciens pv. flaccumfaciens, ocupa a seguinte posição taxonômica: Domínio Bacteria; Filo Actinobacteria; Classe Actinobacteria; Subclasse Actinobacteride; Ordem Actinomycetales; Subordem Micrococcineae; Família Microbacteriaceae (Bradbury, 1986).

A distribuição geográfica da Curtobacterium flaccumfaciens pv. flaccumfaciens (Cff) é bastante ampla. Existem registros nos seguintes países: Canadá, Estados Unidos e México, na América do Norte; Brasil e Colômbia, na América do Sul; Tunísia e Turquia, na Ásia; Alemanha, Bélgica, Bulgária, Grécia, Hungria, “antiga” Iugoslávia, Romênia, Rússia e Suíça, na Europa; Austrália, na Oceania (Bradbury, 1986; Commonwealth Mycological Institute, 
1992; Hedges, 1922; Maringoni \& Rosa, 1997; Uesugi et al., 2003; Nunes et al., 2004; Rava et al., 2004; Theodoro e Maringoni, 2004).

No Brasil, Cff era considerada uma praga quarentenária, sendo que em 1995 foi relatada por Maringoni \& Rosa (1997), em uma lavoura de feijoeiro, cultivar Carioca, localizada no município de Itaporanga, Estado de São Paulo, e a partir de 2001, ela foi observada em diferentes regiões produtoras de feijão nos Estados do Paraná e Santa Catarina (Leite Jr. et al., 2001), Goiás e no Distrito Federal (Uesugi et al., 2003). Na safra de 2011/2012 no Estado do Paraná, foi relatado pela primeira vez Cff em lavouras de soja no Brasil (Soares et al., 2013).

Curtobacterium flaccumfaciens pv. flaccumfaciens é uma bactéria gram-positiva, aeróbia estrita, móvel, com um a três flagelos laterais peritríquos e não formadora de endósporo. Apresentam-se em forma de bastonete isolado ou em pares, com 0,4-0,6 x 0,6-3,0 $\mu \mathrm{m}$ de diâmetro. As colônias em meio de cultura podem ser amarelas, de forma circular, com bordos lisos, planas ou levemente convexas e de aspecto brilhante. (Hayward \& Waterston, 1965). Em meio de cultura extrato de levedura-glicose-ágar, as bactérias apresentam colônias ligeiramente convexas, sem viscosidade, semifluidas e de coloração amarela, laranja ou vermelha, podendo também produzir um pigmento solúvel em água de coloração azul ou púrpura (Davis \& Vidaver, 2001). Além disso, desenvolve-se bem em temperaturas ótimas de 24 a $37^{\circ} \mathrm{C}$, com temperaturas máximas entre 35 a $37^{\circ} \mathrm{C}$, apresenta tolerância a presença de sal, com $7 \%$ a $9 \%$ de $\mathrm{NaCl}$, e requer tiamina, biotina e pantotenato para crescimento. Produz ácido a partir de arabinose, celobiose, frutose, galactose, glucose, glicerol, inositol, maltose, melobiose, rafinose, sacarose e xilose e, usualmente a partir de inositol e melozitol. É catalase positiva, mas oxidase, tirosinase, urease e indol negativa. Não reduz nitrato a nitrito, não produz amônia a partir de peptona, mas produz $\mathrm{H}_{2} \mathrm{~S}$ a partir de cisteína. Não produz aminoácido-descarboxilases ou fenilalanina desaminase (Bradbury, 1986). 
A bactéria é uma espécie fitopatogênica e caracteriza-se por colonizar os vasos xilemáticos, obstruindo a passagem de seiva, causando murcha, flacidez, amarelecimento das folhas, queima ou encarquilhamento do bordo foliar, escurecimento vascular, nanismo, enfezamento nas plantas e, consequentemente, morte da parte aérea do feijoeiro e/ou redução do seu potencial produtivo (Wendland, 2008). Os sintomas são mais agudos nas plantas em períodos de estresse hídrico e temperaturas elevadas e em plantas jovens, até 5-8 $\mathrm{cm}$ de altura (TEGLI et al., 2002).

As sementes contaminadas internamente apresentam coloração amarelada, laranja ou púrpura, como consequência do crescimento bacteriano e se tornarem enrugadas, mas na maioria das vezes nenhum sintoma é visível. (Tegli et al., 2002).

Os sintomas da doença nas lavouras geralmente aparecem em reboleiras, embora plantas isoladas possam ser encontradas (Valentini et al., 2010).

Os sintomas de escurecimento vascular, conjuntamente com os sintomas de murcha, se assemelham aos sintomas da Murcha de Fusarium, causado pelo fungo Fusarium oxysporum f.sp. phaseoli, motivo este que promove uma confusão na detecção da doença a campo. A semelhança entre os sintomas da Murcha de Curtobacterium e a Murcha de Fusarium provavelmente foi um dos motivos que atrasou a constatação da doença no território brasileiro (Uesugi et al., 2003).

Em experimentos de campo e análises em lavouras de feijoeiro no Distrito Federal e entorno, para caracterização dos sintomas causados por Cff em feijoeiro, Miranda Filho (2010) observou que a murcha propriamente dita, sintoma típico na caracterização da doença, geralmente não ocorre nos estádios inicias da cultura, aparecendo geralmente nos estádios reprodutivos, coincidindo com a fase de maior necessidade hídrica da cultura. 
Em soja a doença é chamada de "tan spot". Os sintomas são bem distintos daqueles do feijoeiro, com as folhas apresentado clorose e lesões que se iniciam nas margens foliares e progridem para a região central (Dunleavy, 1983).

Curtobarterium flaccumfaciens pv. flaccumfaciens possui várias hospedeiras, mas restrito apenas às leguminosas. Entre os relatos estão, feijão comum e de vagem (Phaseolus vulgaris L.), caupi (Vigna unguiculata L.), ervilha (Pisum sativum), feijão asiático Adzuki (Vigna angularis Willd.), feijão ayocote (Phaseolus coccineus L.), feijão de lima (Phasolus lunatus L.), feijão mungo (Vigna radiata L.), lab-lab (Lablab purpureus), soja (Glycine max L.) e Zornia spp. (Bradbury, 1986; Dunleavy, 1983; Hedges, 1922; Leite Júnior et al., 2001; Zaumeyer \& Thomas, 1957; Torres et al., 1982).

A principal forma de disseminação de $C f f$ é por sementes contaminadas, as quais podem estar infectadas internamente ou apenas infestadas superficialmente (Tegli et al., 2002). Nas sementes contaminadas internamente, a bactéria fica alojada nas células paliçadicas que formam a testa (Chavarro et al., 1985). Não há disseminação por chuva e água de irrigação, devido à bactéria colonizar internamente os tecidos vasculares. No entanto, dissemina-se rapidamente após chuva de granizo devido aos ferimentos causados. A bactéria pode penetrar na ausência de chuvas, não sendo observada a penetração via estômato. Não há relatos de vetores para disseminação de Cff, porém, o nematóide Meloidogyne incognita pode favorecer a sua penetração através de ferimentos (Schuster, 1959). No entanto Salgado et al., 2007 não constatou a interação patogênica entre $C f f$ e $M$. incognita (raça 2) na infecção e na manifestação dos sintomas da Murcha de Curtobacterium em plantas de feijoeiro das cultivares Pérola e IAPAR 16.

Miranda Filho (2010) avaliou a disseminação de Cff entre plantas de feijoeiro, cultivar Pérola, via parte aérea e sistema radicular. Para avaliação da disseminação via parte aérea foi realizando experimento em casa de vegetação de forma que não houvesse contato entre o 
sistema radicular das plantas, para tal as mesmas foram arranjadas de modo que elas ficassem espaçadas a $0,10 \mathrm{~m}$ para simular o arranjo entre plantas e $0,50 \mathrm{~m}$ para simular o espaçamento entre linhas. Já para avaliação da disseminação via sistema radicular, o experimento foi realizado em condições de campo, onde foram usados os mesmos espaçamentos do ensaio anterior, mas de modo que não houvesse contato entre as plantas via parte aérea. De acordo com os resultados obtidos, a transmissão via parte aérea foi de $20 \%$ nos dois espaçamentos e pelo sistema radicular foi de $16,7 \%$ para espaçamento de $0,10 \mathrm{~m}$ e de $10 \%$ no espaçamento de $0,50 \mathrm{~m}$.

O patógeno pode sobreviver nas sementes, por até dois anos ou por períodos mais longos quando a semente é armazenada em condições ótimas (Tegli et al., 2002).

Curtobarterium flaccumfaciens pv. flaccumfaciens também pode sobreviver no solo, servindo de inóculo por períodos de até dez meses. Além disso, a bactéria virulenta sobrevive em plantas não hospedeiras com Amaranthus retroflexus e Chenopodium album, por até dez meses, enquanto estirpes não virulentas sobrevivem por até vinte dois meses (Schuster, 1967).

Miranda Filho (2010) avaliando a persistência de Cff em solo de cerrado, tipo latossolo vermelho, cultivado com feijoeiro comum durante três safras consecutivas e com alta incidência de Murcha de Curtobacterium, observou que a bactéria permaneceu viável no solo por um período de aproximadamente vinte e dois meses.

Embora exista uma intensa busca por métodos de controle da Murcha de Curtobacterium (Estefani et al., 2007; Rodrigues et al., 2006; Soares et al., 2004; Theodoro \& Maringoni, 2006a; Theodoro \& Maringoni, 2006b;) seu controle está baseado somente no uso de sementes sadias, rotação de culturas e cultivares com algum nível de resistência genética (Hall, 1991; Maringoni, 2002).

O emprego de sementes sadias, já que o patógeno sobrevive e é transmitido por sementes (Saettler \& Perry, 1972), tem sido adotado em alguns países, através da certificação 
sanitária. Esta medida foi tão eficaz que durante 20 anos a Murcha de Curtobacterium não foi constatada em áreas de produção de Dakota do Norte e em Minessota, E.U.A., e que apenas em 1994 Cff foi isolado de uma amostra de sementes utilizada por um agricultor daquela região (Venette et al., 1995).

O uso de resistência genética é o método mais eficiente para controlar a ocorrência de doenças em plantas por apresentar menor custo, ser de fácil utilização, além de não apresentar riscos para o homem e o meio ambiente (FRY,1982).

A identificação de fontes de resistência é uma demanda para as pesquisas e a primeira etapa do melhoramento quando se pensa na obtenção da resistência a doenças (Faleiro, 2007). Várias pesquisas foram iniciadas no final da década de 50 e no início da década de 60, visando selecionar fontes de resistência em feijoeiro à Murcha de Curtobacterium (Coyne $e t$ al., 1963).

$\mathrm{Na}$ literatura internacional há relatos de diversos genótipos de feijoeiro, com elevado nível de resistência à Murcha de Curtobacterium (Chavarro et al.,1985; Coyne \& Schuster, 1974; Huang et al., 2007b; Hsieh et al., 2003, Hsieh et al., 2005; Karkmkova \& Boyadzhiev, 1984; Nikitina et al., 1980; Phang et al.,1974).

No Brasil, trabalhos avaliando a resistência ou tolerância de cultivares têm sido realizados, no entanto, apenas alguns genótipos contêm genes de resistência à Murcha de Curtobacterium. Maringoni (2002), avaliando quarenta cultivares de feijoeiro através da inoculação em separado de dois isolados de Cff, verificou que as cultivares IAC Carioca Akytã, IAC Carioca Aruã e IAC Carioca Pyatã são resistentes à Murcha de Curtobacterium. Estas cultivares apresentaram menor severidade a doença e menor redução da matéria seca da parte aérea em relação às suscetíveis (IAC Carioca e Pérola), quando inoculadas com Cff.

Theodoro et al., (2007) avaliaram a reação de 73 cultivares locais de feijoeiro, coletadas em Santa Catarina, à Murcha de Curtobacterium, e identificaram como fonte de 
resistência as cultivares Mouro Piratuba (grupo de coloração variada) e Vagem Amarela (grupo preto).

Rava et al., (2003) identificaram os materiais 'CF 800375', 'Coquinho Enxofre', 'Feijão Baetão', 'Mulatinho MG' e 'Vermelho 1 Epamig' como resistentes à Murcha de Curtobacterium, entre 333 cultivares locais coletadas em sete estados brasileiros.

Souza et al., (2006) avaliaram 333 acessos pertencentes ao banco de germoplasma de feijão do Instituto Agronômico de Campinas (IAC). Os resultados da triagem da resistência genética em genótipos de feijoeiro indicaram a existência de variabilidade genética nas amostras dos 333 genótipos avaliados. Os materiais foram classificados em 4 grupos de resistência: 29 genótipos $(8,7 \%)$ comportaram-se como altamente resistentes, 13 genótipos (3,9\%) como resistentes, 18 genótipos (5\%) como moderadamente resistentes e 273 genótipos (81\%) suscetíveis.

Krause et al., (2009) avaliaram 39 genótipos, sendo trinta e três de feijão de vagem e seis de feijão comum, destes, 'Novirex', 'IAC Carioca Tybatã' e 'Amarelo Baixo' foram identificados como resistentes.

A presença de restos culturais de feijoeiro infectados com Cff em campos de cultivo de feijoeiro pode ser uma importante fonte de inóculo para a ocorrência de epidemias de Murcha de Curtobacterium, sendo recomendada a incorporação desses restos culturais, e a adoção de rotação de cultura com espécies vegetais não-hospedeiras do patógeno. Trabalho realizado por Silva Júnior (2011) mostrou que $C f f$ sobrevive por até 240 dias em restos culturais de feijoeiro mantidos na superfície do solo e por até 30 dias quando incorporados a $20 \mathrm{~cm}$ de profundidade.

A utilização do tratamento de sementes com agentes de controle biológico pode ser uma alternativa para o controle da Murcha de Curtobacterium. Huang et al., (2007a) avaliaram a eficiência do tratamento de sementes de feijão, inoculadas e naturalmente 
infectadas com Cff, com os isolados de Rhizobium leguminosarum bv. viceae R12 e R21, $R$. leguminosarum bv. phaseoli BR e Pantoea agglomerans PA. Todos os agentes de controle biológico reduziram a incidência e severidade da Murcha de Curtobacterium, além de promoverem um aumento na emergência e altura de plântulas, sendo o isolado $R$. leguminosarum bv. viceae $\mathrm{R} 21$ o agente mais eficaz.

Análises visuais das sementes são insuficientes para determinar a presença ou não de bactérias fitopatogênicas. Deste modo, existe a necessidade de testes que possibilitem detectar bactérias em sementes, especialmente quando o nível de infecção é muito baixo (Oliveira, 1995). As avaliações de sanidade, visando à identificação de patógenos e descarte dos lotes contaminados, asseguram a sanidade dos lotes a serem comercializados e assim, evitar a ocorrência de epidemias generalizadas (Valentini et al., 2010).

Em fitobacteriologia os meios semi-seletivos são considerados uma ferramenta de relevante importância para o diagnóstico de doenças, estudos epidemiológicos e para o isolamento de bactérias fitopatogênicas em tecidos vegetais e/ou sementes (Kruppa, 1993). Por meio do uso do meio de cultura MSCFF desenvolvido por Maringoni et al. (2006), houve a constatação da viabilidade de métodos qualitativos para a detecção de $C f f$ em lotes de sementes de feijoeiro, em exames de rotina laboratorial. Foi detectada a presença desta bactéria em metade dos trinta lotes de sementes de feijoeiro avaliados e óbitos nos Estados de São Paulo, Paraná, Goiás e Rio Grande do Sul (Maringoni \& Câmara, 2006).

Ajustes no meio CNS (Corynebacterium Nebraskense Selective Medium) foram propostas por Behlau et al. (2006) para recuperação e detecção de Cff em solo e sementes de feijoeiro. Os resultados obtidos mostraram a eficiência do meio CNS - modificado na recuperação de $C f f$ de amostras de solo e sementes de feijão contaminadas por esta bactéria, podendo ser utilizado como ferramenta em estudos epidemiológicos e ecológicos da bactéria, assim como em análises fitossanitárias de sementes de feijoeiro. 
Morais et al. (2010) compararam a eficiência dos meios semi-seletivos MSCFF e CNS modificado para a detecção de $C f f$, através dos métodos de repicagem por estria e por espalhamento, em sementes de feijoeiro. Os resultados evidenciaram uma maior rapidez no crescimento de Cff no meio semi-seletivo MSCFF, o qual pode ser utilizado em análises de rotina para detecção de $C f f$ em sementes de feijão, pela facilidade de elaboração, pela rapidez de detecção e também pelo baixo custo.

Técnicas moleculares estão sendo utilizadas em estudos de variabilidade genética, diagnose, identificação e caracterização de isolados bacterianos (Valentini et al., 2010). Tegli et al. (2002), demonstraram a eficiência dos iniciadores CffFOR2-CffREV4, obtidos a partir do fragmento amplificado via PCR baseado na sequência repetitiva (Rep-PCR), na detecção de $C f f$ em sementes de feijão.

Os oligonucleotídeos CF4-CF5 desenvolvidos por Guimarães et al. (2001), em PCR a partir de sequência de fragmentos obtidos de DNA cromossômico por sub-clonagem da porção específica hibridizada para $C f f$, demonstraram alta especificidade para a detecção dos isolados de Cff utilizados pelos autores. No entanto no trabalho realizado por Souza et al. (2006), os iniciadores CF4-CF5 não foram capazes de detectar dois isolados, já os oligonucleotídeos CffFOR2-CffREV4 detectaram todos os 24 isolados de Cff. Deuner (2007) observou que a utilização os oligonucleotídeos $C f f F O R 2-C f f R E V 4$, na detecção de $C f f$ em sementes de feijão, apresentam maior repetibilidade e eficiência quando comparado com os CF4-CF5.

As técnicas moleculares surgem como importante ferramenta para detecção de Cff, principalmente quando se têm disponíveis primers específicos que detectam eficientemente o patógeno alvo (Deuner, 2007). 


\subsection{Tratamento de Sementes}

Uma significante parcela dos agentes fitopatogênicos encontra-se comumente associada às sementes de plantas (Tanaka \& Machado, 1985). Entre os agentes que podem ser transmitidos pelas sementes, o grupo dos fungos é o mais numeroso, seguido de bactérias, vírus e nematóides (Machado, 2000).

São considerados patógenos de sementes aqueles microrganismos que se encontram em mistura ou diretamente associados a sementes em um dado lote. Essa localização é importante, pois dela depende a escolha para exame de sanidade e o tratamento fitossanitário a ser recomendado (Tanaka \& Machado, 1985; Blum et al., 2006). De modo geral, o transporte de patógenos por sementes pode ser efetuado de três maneiras: 1) O patógeno acompanha a semente, mas não está intimamente ligado a ela. Também chamado de contaminação concomitante, nesse tipo de associação, o patógeno, presente em fragmentos de plantas ou partículas de solo, em formas de estruturas de resistência como esclerócios ou cistos (nematóides), se mistura às sementes durante os processos de colheita e beneficiamento e com elas é levado ao campo por ocasião da semeadura. 2) O patógeno é carregado de forma passiva, aderido a superfície da semente, sem associação com tecidos internos. Geralmente esse tipo de associação é comum a certos vírus, nematóides e alguns fungos na forma de escleródios, esporos e micélio. 3) O patógeno é transportado nos tecidos internos da semente (várias camadas do envoltório ou no embrião). Nesse caso a semente infectada normalmente não mostra sintomas visíveis, uma vez que o patógeno localiza-se internamente (Tanaka \& Machado, 1985; Machado, 1988).

A semente constitui num meio importante de disseminação de patógenos, sendo considerada mais eficiente que os demais meios conhecidos. Dentre as causas, citam-se: por ser rica em proteínas, carboidratos e minerais, a semente é um ótimo substrato nutritivo para sobrevivência de inúmeros patógenos; por permanecer viável por longo tempo, a semente 
permite, em consequência, a sobrevivência dos patógenos por longos períodos de tempo; por contactar diretamente com a semente dos hospedeiros, o patógeno mantém assegurada a patogenicidade, que tenderia a diminuir ou desaparecer, se a associação fosse com o solo, restos de cultura entre outros; o plantio de uma semente infectada faz com que o patógeno tenha sua introdução assegurada no local; a semente infectada permite o desencadeamento da doença já nos primeiros estádios do ciclo da planta; se o patógeno veiculado pela semente sobreviver no solo por longo tempo, mesmo utilizando-se sementes sadias nos plantios subsequentes, poderá haver manifestação da doença (Tanaka \& Machado, 1985).

O controle de doenças, em se tratando de sementes, segue, de modo geral, as mesmas regras conhecidas para o controle de qualquer outro tipo de doença em plantas. O tratamento de sementes para redução de inóculo veiculado por elas é prática das mais antigas na história de controle de doenças de plantas (Machado, 2000). A prática era usada séculos antes do nascimento da fitopatologia, embora bases científicas tenham sido desenvolvidas após o famoso plantio de sementes de trigo danificadas por água do mar em 1660, que produziu a lavoura livre de cáries (Dhingra, 2005).

O tratamento de sementes constitui em procedimento biológico, químico ou físico, visando reduzir ou erradicar fitopatógenos associados externamente ou internamente às sementes. O objetivo final é permitir a emergência de plântulas sadias e evitar a posterior disseminação de patógenos (Oliveira et al., 2005).

Pela sua simplicidade de execução, menores riscos de intoxicação humana e poluição do ambiente, eficiência e baixo consumo de material, o tratamento de sementes é umas das medidas de controle mais praticadas na agricultura moderna (Jeffs, 1986 citado por Machado, 2000). A sua eficiência depende, basicamente, do tipo e localização do patógeno-alvo, do vigor da semente e da existência de substâncias e processos eficazes (Menten, 1995). 
Entre os métodos de tratamento de sementes descritos na literatura incluem-se métodos físicos, químicos e biológicos. Em menor escala, o tratamento bioquímico tem sido praticado em alguns casos (Dhingra et al., 1980; Machado, 2006).

Entende-se por tratamento químico a aplicação de fungicidas, antibióticos e nematicidas às sementes. É o método mais comum de se tratar sementes, sendo de grande valor comercial. O seu princípio é bastante simples e baseia-se na existência de produtos eficientes contra os patógenos, que apresentem baixa fitotoxicidade e sejam pouco tóxicos ao homem e ao ambiente. É um método bastante diversificado e em expansão, frequentemente surgem novos produtos com características desejáveis (Menten, 1995).

Entre os métodos físicos, predominam os que preconizam o uso do calor aplicado por meio da exposição das sementes a temperaturas que sejam letais ao patógeno, porém, que causem o mínimo de danos à viabilidade das sementes. Entre esses, está à imersão de sementes em água aquecida, o uso de calor seco, a corrente de vapor e o tratamento com energia solar (Grondeau \& Samson, 1994). Cuidados devem ser tomados, pois a diferença entre a temperatura letal ao patógeno e aquela que inviabiliza a semente é em geral pequena, por isso é essencial o controle preciso da temperatura (Rat, 1987). O tratamento via calor seco, apresenta menor capacidade térmica ou troca de calor que a via úmida, requerendo, portanto, maior tempo de exposição. Entretanto, é mais simples e mais acessível, além de causar menos danos às sementes, já que não há o rompimento do tegumento e/ou extravasamento de substâncias das sementes, comum na embebição em água quente e vapor arejado (Menten, 1995).

O tratamento biológico é a incorporação artificial de agentes de controle biológico às sementes. O seu principio básico é a ação de "controle biológico" exercido por determinados microrganismos, que eliminam, impedem ou reduzem o desenvolvimento de patógenos transportados pelas sementes (durante o armazenamento ou após a semeadura), ou presente no 
solo, também existe a possibilidade de "indução de resistência" contra os patógenos de parte aérea. Estes microrganismos atuam basicamente através do antagonismo, hiperparasitismo e competição (Menten, 1995). Entretanto, a recomendação mais extensiva deste tratamento é ainda prematura uma vez que a seleção de organismos com maior capacidade de adaptação ainda permanece como desafio. É possível que métodos em desenvolvimento pela Biotecnologia auxiliem no controle biológico de patógenos em sementes (Machado, 2000).

O tratamento bioquímico consiste em submeter às sementes a uma fermentação anaeróbica, por tempo determinado. Trata-se de um procedimento de emprego limitado a poucas espécies e de pouco valor comercial, também não apresenta ação residual. O principio do processo é a sensibilidade de patógenos às substâncias químicas formadas durante a fermentação anaeróbica, assim deve ser criadas condições de umidade e temperatura para que ocorra formação de ácidos que inativem os patógenos. Na prática, as sementes de tomate são extraídas após a fermentação durante 96 horas, a $21{ }^{\circ} \mathrm{C}$, onde através deste processo, realizase o controle de Clavibacter michiganensis subsp. michiganensis, agente causal do cancro do tomateiro (Dhingra et al., 1980; Machado, 1988; Menten, 1995).

\subsection{Ozônio como agente antimicrobiano}

O ozônio $\left(\mathrm{O}_{3}\right)$, forma triatômica do oxigênio, é um gás incolor, instável, muito reativo é tóxico (Rice \& Netzer 1982).

O ozônio foi descoberto pela primeira vez em 1839 por Schönbein, estudando a decomposição eletrolítica da água (Tiwari \& Rice, 2012). Somente após duas décadas de sua descoberta ficou claramente identificada a composição triatômica do ozônio, contendo apenas oxigênio (Vidal, 2003).

O ozônio é formado naturalmente na estratosfera em pequenas quantidades $(0,05$ mg/L) pela ação da radiação ultravioleta do sol sobre o oxigênio. Uma pequena quantidade de 
ozônio também é formada na troposfera como subproduto das reações fotoquímicas entre hidrocarbonetos, oxigênio e nitrogênio que são lançados por automóveis, indústrias, florestas e ação vulcânica. Porém, o gás produzido é muito instável e decompõe-se rapidamente no ar (Prestes, 2007).

Para a geração de ozônio, deve-se dividir primeiramente uma molécula de oxigênio diatômico. O oxigênio livre resultante da quebra da molécula de oxigênio pode reagir com outras moléculas de oxigênio para formar as moléculas de ozônio. Porém para quebrar a molécula de oxigênio uma grande quantidade de energia é requerida (Russel et al.,1999; USEPA, 1999). O ozônio pode ser produzido por métodos fotoquímico e de descarga elétrica, além disso, ainda pode ser produzido por método térmico, radioquímico e eletroquímico (Kim et al., 1999; Langlais et al., 1991).

A molécula de ozônio possui o segundo maior potencial de oxidação entre os elementos químicos, sendo superada somente pela molécula de flúor $\left(\mathrm{F}_{2}\right)$. Em condições normais de temperatura e pressão o ozônio é moderadamente solúvel em água: 13 vezes mais solúvel que o $\mathrm{O}_{2}$. É facilmente detectável em concentrações muito baixas, na faixa de 0,01 a 0,05 $\mathrm{mg} \mathrm{L}^{-1}$ (Rice \& Netzer, 1982).

O ozônio é instável à pressão e temperatura ambiente com uma meia vida de cerca de 15 minutos e é decomposto a $\mathrm{O}_{2}$ a temperaturas superiores que $35^{\circ} \mathrm{C}$ (Adaskaveg et al., 2002). Em solução aquosa apresenta meia-vida que varia de 20 a 30 minutos em água destilada a 20 ${ }^{\circ} \mathrm{C}$ (Silva et al., 2011).

A ação germicida do ozônio foi evidenciada na França, no final do século XIX, quando este gás começou a ser utilizado como desinfetante no tratamento de água (Lapolli et al., 2003; Rice et al., 1981). Atualmente, utiliza-se essa tecnologia para outros fins, como tratamento de água de piscinas, para a sanitização de galões de água, de superfícies de alimentos, de plantas e de equipamentos de processamento de alimentos, para desinfecção de 
carcaças, na conservação de frutas e verduras, e no controle de insetos praga de grãos armazenados (Alencar, 2007).

O ozônio é um poderoso agente oxidante, eficaz na inativação de bactérias, fungos, vírus, protozoários, inclusive formas esporuladas e cistos de protozoários, (Souza, 2006; Lapolli et al., 2003; USEPA, 1999).

Cada microrganismo apresenta sensibilidade inerente ao ozônio, de tal forma que as bactérias são mais sensíveis que os fungos e leveduras, bactérias gram-negativas são mais sensíveis que as gram-positivas, e os esporos são mais resistentes que as células vegetativas (Pascual et al., 2007). Fatores fisiológicos e ambientais também exercem influencia no grau de inativação dos microrganismos. A sensibilidade ao ozônio varia de acordo com o pH do meio, a temperatura, a umidade, aditivos (por exemplo, ácidos, agentes tensoativos, e açúcares), e com a quantidade de matéria orgânica em torno das células (Pirani, 2011).

A inativação dos microrganismos pelo ozônio é um processo complexo porque o ozônio interage com numerosos componentes celulares, incluindo proteínas, lipídios insaturados e enzimas respiratórias nas membranas celulares, os peptídioglicanos dos envelopes celulares, enzimas e ácidos nucléicos no citoplasma e proteínas (Pirani, 2011). O ozônio atua inicialmente na membrana celular, sendo a superfície da célula microbiana o primeiro alvo a ser atingido. Sua ação antimicrobiana é decorrente da oxidação de glicolipídeos, glicoproteínas e aminoácidos da parede celular, alterando a permeabilidade e causando sua rápida lise. O ozônio ataca também grupos sulfidrila de enzimas, ocasionando o colapso da atividade enzimática celular. Além disso, sua ação sobre o material nuclear dos microrganismos altera as bases púricas e pirimídicas dos ácidos nucléicos, como ocorre com alguns vírus, onde o ozônio destrói seu RNA além de alterar as cadeias polipeptídicas do cápsideo protéico (Silveira, 2004; Hunt \& Mariñas, 1999). 


\section{Material e Métodos}

\subsection{Isolado de Curtobacterium flaccumefaciens pv. flaccumefaciens}

O isolado de Curtobacterium flaccumefaciens pv. flaccumfaciens (Cff) foi obtido através de amostras de plantas de feijoeiro (Phaseolus vulgaris L.), cultivar Pérola, coletadas na região de Alto Paraíso - GO e depositado na Coleção de bactérias Fitopatogênicas do Departamento de Fitopatologia da Universidade de Brasília, sob o número UnB 1376.

Para isolamento da bactéria, hastes das plantas coletadas foram submetidas ao processo de desinfecção superficial, que consiste da limpeza com papel toalha embebida com etanol $70 \%$ seguido de uma flambagem. Após este processo de desinfecção, as hastes foram cortadas deixando o câmbio vascular exposto para obtenção do material.

Em lâminas de vidro, esterilizadas, juntamente com água destilada e estéril, pequenos fragmentos foram macerados com bastão de vidro e a suspensão obtida foi transferida com uma alça flambada, para placa de Petri contendo meio de cultura 523 (Kado \& Heskett, 1970), e diluído em estrias por esgotamento.

As placas foram incubadas a $28^{\circ} \mathrm{C}$, por 72 horas e foi observada a presença ou não de colônias típicas de $C f f$. As colônias suspeitas foram multiplicadas em meio de cultura 523 (Kado \& Heskett, 1970). Após o desenvolvimento das colônias bacterianas, procederam-se testes de coloração diferencial de Gram e hidróxido de potássio ( $\mathrm{KOH} 3 \%$ ), para que houvesse a confirmação da identidade do microrganismo isolado.

O isolado de Cff foi cultivado em meio de cultura 523 (Kado \& Heskett, 1970) e mantido a temperatura de $28{ }^{\circ} \mathrm{C}$. Para manutenção de sua viabilidade foram realizadas repicagens periódicas durante o desenvolvimento do trabalho. Para preservação, células bacterianas concentradas foram adicionadas em frascos contendo $10 \mathrm{ml}$ de água destilada e estéril. Os frascos foram tampados, agitados, vedados com filme PVC e armazenados a temperatura ambiente. 


\subsection{Patogenicidade e reação de hipersensibilidade do isolado de $C f f$}

Sementes de feijão (Phaseolus vulgaris L.), cultivar Pérola, sabidamente sadias (básicas) foram inoculadas com o isolado UnB 1376, de modo semelhante ao descrito por Estefani, 2004. As sementes foram colocadas dentro de um Becker estéril e cobertas com suspensão bacteriana com concentração ajustada para $10^{8} \mathrm{UFC} / \mathrm{mL}\left(\mathrm{A}_{550}=0,2\right)$. Após 30 minutos, a suspensão foi descartada e as sementes colocadas para secar a temperatura ambiente, por aproximadamente 48 horas, dentro de caixas plásticas do tipo "gerbox" forradas com papel toalha.

Após a inoculação, trinta e seis sementes foram semeadas em vasos, os quais continham o volume de aproximadamente de 3,0 L de solo previamente autoclavado. As plantas desenvolveram-se em condições de casa de vegetação. Como testemunha, foram semeadas sementes comprovadamente sadias. O delineamento experimental foi inteiramente casualizado, com seis repetições. Cada parcela foi constituída de um vaso com seis sementes.

A avaliação foi realizada 30 dias após a semeadura, quando foram observadas plantas com sintomas da doença.

Para determinação da reação de hipersensibilidade, também foi preparado uma suspensão na mesma concentração usada no teste de patogenicidade e em seguida infiltrada por pressão, com auxilio de uma seringa hipodérmica estéril, nos espaços intercelulares na face abaxial das folhas de fumo. Folhas infiltradas somente com água destilada estéril foram utilizadas como testemunha. As plantas foram mantidas em laboratório e as avaliações foram realizadas 24 e 48 horas após a infiltração. 


\subsection{Sensibilidade "in vitro" de $C f f$ a diferentes produtos fitossanitários}

O experimento foi realizado no Laboratório de Bacteriologia do Departamento de Fitopatologia da Universidade de Brasília.

Sete produtos fitossanitários foram selecionados para avaliação da sensibilidade "in vitro" do isolado UnB 1376 de Cff (Tabela 2.1).

Tabela 2.1. Produtos fitossanitários selecionados para avaliação da sensibilidade in vitro, do isolado UnB 1376 de Curtobacterium flaccumfaciens pv. flaccumfaciens.

\begin{tabular}{|c|c|c|c|c|c|c|}
\hline $\begin{array}{c}\text { Princípio } \\
\text { Ativo }\end{array}$ & $\begin{array}{c}\text { Grupo } \\
\text { Químico }\end{array}$ & Classe & Marca $®$ & Formulação ${ }^{(1)}$ & $\begin{array}{l}\text { Modo de } \\
\text { Ação }\end{array}$ & $\begin{array}{c}\text { Concentração } \\
\text { g/Kg-L }{ }^{(2)}\end{array}$ \\
\hline $\begin{array}{l}\text { Hidróxido de } \\
\text { Cobre }\end{array}$ & Inorgânico & Bactericida/Fungicida & Kocide & WG & Contato & $350^{(3)}$ \\
\hline $\begin{array}{l}\text { Oxicloreto de } \\
\text { Cobre }\end{array}$ & Inorgânico & Bactericida/Fungicida & $\begin{array}{c}\text { Cuprogarb } \\
350\end{array}$ & WP & Contato & $350^{(3)}$ \\
\hline Óxido Cuproso & Inorgânico & Bactericida/Fungicida & Cobre Atar & WP & Contato & $500^{(3)}$ \\
\hline $\begin{array}{l}\text { Sulfato de } \\
\text { Cobre }\end{array}$ & Inorgânico & Bactericida/Fungicida & $\begin{array}{l}\text { Cupro- } \\
\text { dimy }\end{array}$ & WP & Contato & $200^{(3)}$ \\
\hline Casugamicina & Antibiótico & Bactericida/Fungicida & Kasumin & SL & Sistêmico & 20 \\
\hline $\begin{array}{l}\text { Cloretos de } \\
\text { benzalcônio }\end{array}$ & $\begin{array}{c}\text { Amônio } \\
\text { Quaternário }\end{array}$ & Bactericida/Fungicida & Fegatex & SL & Contato & 100 \\
\hline $\begin{array}{c}\text { Ácido } \\
\text { Peracético }\end{array}$ & $\begin{array}{l}\text { Peróxido } \\
\text { Orgânico }\end{array}$ & Bactericida/Fungicida & Peracetic & SL & Contato & 170 \\
\hline
\end{tabular}

Para realização dos testes de sensibilidade foi preparada uma suspensão bacteriana. A suspensão bacteriana foi preparada a partir de células crescidas em meio 523 (Kado \& Heskett, 1970), por 72 horas a temperatura de $28{ }^{\circ} \mathrm{C}$. Após o crescimento das células, as mesmas foram colhidas do meio de cultura e colocadas em tubos de ensaio contendo $10 \mathrm{ml}$ de água destilada e esterilizada. A concentração obtida foi de aproximadamente $10^{8} \mathrm{UFC} / \mathrm{mL}$ ajustada em espectrofotômetro $\left(\mathrm{A}_{550}=0,2\right)$. Em seguida, a suspensão foi diluída em série até a $10^{-5}$ 


\subsubsection{Sensibilidade "in vitro" de $C f f$ ao cobre}

Nos os testes de sensibilidade "in vitro" ao cobre foi utilizado o meio CYE-glycerol (casitone yeast extract-glycerol) (Zevenhuizen et al., 1979), contendo 1,7 g/L de casitona; 0,35 g/L de extrato de levedura; 2,0 g/L de glicerol e $15 \mathrm{~g} / \mathrm{L}$ de ágar, que possui baixa capacidade de complexar íons de cobre.

Foram utilizados quatro ingredientes ativos: hidróxido de cobre, oxicloreto de cobre, óxido cuproso e sulfato de cobre. Cada produto foi adicionado ao meio de cultura CYEglycerol, após autoclavagem e quando este atingiu temperatura média de $50^{\circ} \mathrm{C}$, de modo se obter concentrações de $0,10,20,30,40,50,100$ e $200 \mu \mathrm{g} / \mathrm{mL}$ de cobre metálico. Para isto foi preparadas uma solução estoque na concentração de $2 \times 10^{4} \mu \mathrm{g} / \mathrm{mL}$, a qual foi adicionada ao meio assepticamente em determinado volume para obtenção da concentração desejada (Tabela 2.2). Cada frasco tipo Erlenmeyer contendo o meio de cultura foi agitado manualmente para que o produto se misturasse por igual e em seguida o meio foi vertido em cinco placas de Petri estéreis. Como testemunha, foi vertido meio de cultura sem adição de produto.

Após solidificação do meio de cultura uma alíquota de $50 \mu \mathrm{L}$ da suspensão bacteriana e diluída a $10^{-5}$, foi depositada e espalhada, com auxilio de uma alça de Drigalski flambada, sobre o meio CYE-glycerol contendo cobre nas concentrações desejadas. Após o plaqueamento, as placas foram incubadas a $28^{\circ} \mathrm{C}$. Para cada concentração foram realizadas cinco repetições, sendo cada repetição representado por uma placa.

A avaliação foi realizada após 48 horas de incubação, através da contagem de colônias, expressas em unidade formadora de colônia (UFC) de cada placa. Em seguida foi calculado a média entre as cinco placas e os dados transformados em UFC/mL.

O ingrediente ativo que em menor concentração não permitiu o crescimento bacteriano foi selecionado para o tratamento das sementes. 
Tabela 2.2. Volume de solução estoque necessário para obtenção da concentração de cobre metálico desejada, em meio de cultura.

\begin{tabular}{cccc}
\hline $\begin{array}{c}\text { Concentração de cobre } \\
\text { metálico desejada } \\
(\boldsymbol{\mu g} / \mathbf{m L})\end{array}$ & $\begin{array}{c}\text { Volume de solução } \\
\text { estoque adicionado ao } \\
\text { meio de cultura }(\mathbf{m L})\end{array}$ & $\begin{array}{c}\text { Volume inicial do } \\
\text { meio de cultura }(\mathbf{m L})\end{array}$ & $\begin{array}{c}\text { Volume final do } \\
\text { meio de cultura } \\
(\mathbf{m L})\end{array}$ \\
\hline 0 & 0 & 100 & 100 \\
10 & 0,05 & 99,95 & 100 \\
20 & 0,10 & 99,90 & 100 \\
30 & 0,15 & 99,85 & 100 \\
40 & 0,20 & 99,80 & 100 \\
50 & 0,25 & 99,75 & 100 \\
100 & 0,5 & 99,50 & 100 \\
200 & 1,0 & 99,00 & 100 \\
\hline
\end{tabular}

\subsubsection{Sensibilidade "in vitro" de $C f f$ a casugamicina}

A casugamicina foi adicionada ao meio de cultura 523 (Kado \& Heskett, 1970), após autoclavagem, quando este atingiu a temperatura média de $50{ }^{\circ} \mathrm{C}$, de modo a se obter concentrações de $0,1,5,10,20,25,50,100$ e $200 \mu \mathrm{g} / \mathrm{mL}$ do ingrediente ativo. Após a adição, os procedimentos foram os mesmos citados no item 2.3.1. A menor concentração que não permitiu o crescimento bacteriano foi selecionada para o tratamento das sementes.

\subsubsection{Sensibilidade "in vitro" de $C f f$ aos cloretos de benzalcônio}

Os cloretos de benzalcônio foram adicionados ao meio de cultura 523 (Kado \& Heskett, 1970), após autoclavagem, quando este atingiu a temperatura média de $50{ }^{\circ} \mathrm{C}$, de modo a se obter concentrações de $0,20,40,60,80,100$ e $200 \mu \mathrm{g} / \mathrm{mL}$ do principio ativo. Após a adição, os procedimentos foram os mesmos citados no item 2.3.1. A menor concentração que não permitiu o crescimento bacteriano foi selecionada para o tratamento das sementes. 


\subsubsection{Sensibilidade "in vitro" de Cff ao ácido perácetico}

O ácido peracético foi adicionado ao meio de cultura 523 (Kado \& Heskett, 1970), após autoclavagem, quando este atingiu a temperatura média de $50^{\circ} \mathrm{C}$, de modo a se obter concentrações de $0,100,200,300,400,500,1000,1500$ e $2000 \mu \mathrm{g} / \mathrm{mL}$ do principio ativo. Após a adição, os procedimentos foram os mesmos citados no item 2.3.1. A menor concentração que não permitiu o crescimento bacteriano foi selecionada para o tratamento das sementes.

\subsection{Avaliação do efeito diferentes tratamentos de semente na erradicação de $C f f$}

O experimento foi realizado no Laboratório de Bacteriologia do Departamento de Fitopatologia da Universidade de Brasília.

Utilizaram-se sementes de feijão (Phaseoulus vulgaris L.), cultivar Pérola, sabidamente sadias (semente básica). As sementes foram inoculadas por imersão em suspensão bacteriana. Para preparo da supensão foi utilizado isolado UnB 1376 de Cff.

Foram comparados os tratamentos de sementes: imersão em solução com os produtos fitossanitários nas concentrações selecionadas nos testes "in vitro"; exposição a vapor de etanol e metanol; ozonização. Como testemunha utilizou-se sementes inoculadas e não tratadas. Para cada tratamento foram utilizadas 200 sementes. Após os tratamentos as sementes foram armazenadas em temperatura ambiente em envelopes de papel devidamente identificados até o momento da avaliação da incidência e quantificação de $C f f$.

\subsubsection{Inoculação das sementes}

Para inoculação empregou-se a metodologia semelhante ao descrito por Estefani, 2004. As sementes foram colocadas dentro de um Becker estéril e cobertas com suspensão bacteriana com concentração ajustada para $10^{8} \mathrm{UFC} / \mathrm{mL}\left(\mathrm{A}_{550}=0,2\right)$. Após 30 minutos, a 
suspensão foi descartada e as sementes colocadas para secar a temperatura ambiente, por aproximadamente 48 horas, dentro de caixas plásticas do tipo "gerbox" forradas com papel toalha.

Após a inoculação foi realizado um teste para avaliar a existência de colonização interna das sementes pela bactéria. Para tal, foi utilizada metodologia semelhante à descrita por Deuner, 2007. Foi selecionada uma amostra de 90 sementes inoculadas. Essas sementes foram dividias em duas subamostras, nas quais metade das sementes foi submetida à desinfestação superficial e a outra metade não. As sementes com desinfestação superficial foram imersas em solução de hipoclorito de sódio $(\mathrm{NaOCl} 0,5 \%)$ durante 2 minutos e em seguida, lavadas três vezes em água destilada esterilizada. Posteriormente, sementes, com e sem desinfestação superficial, foram colocadas individualmente em tubos de ensaio com 9 mL de água destilada esterilizada e incubadas em câmara fria por 18 horas à temperatura de $5^{\circ} \mathrm{C}$. Decorrido esse tempo, alíquotas de $100 \mu \mathrm{L}$ de cada suspensão foram depositadas e espalhadas, com auxilio de uma alça de Drigalski flambada em meio de cultura 523 (Kado \& Heskett, 1970). Para cada suspensão foram realizadas três repetições, de uma placa cada, perfazendo um total de 135 placas por subamostra. Em seguida as placas foram incubadas a $28^{\circ} \mathrm{C}$ por 72 horas e posteriormente contou-se o número de colônias.

\subsubsection{Tratamento de sementes de feijão com os produtos fitossanitários}

As sementes foram colocadas em um Becker de vidro e cobertas com solução dos produtos nas concentrações selecionadas "in vitro". Foi utilizado um volume de solução duas vezes maior que o volume de sementes. Estas permaneceram imersas na solução por 15 minutos. Em seguida a solução foi descartada e a sementes colocadas para secar dentro de caixas tipo "gerbox" forradas com papel toalha por 48 horas. 


\subsubsection{Tratamento de sementes de feijão com vapores de etanol e metanol}

As amostras de sementes foram tratatadas mediante exposição a vapor de etanol $\left(96^{\circ}\right.$ GL) e metanol (99,8 $\left.8^{\circ} \mathrm{GL}\right)$. Para tal foi adaptado um recipiente plástico como compartimento individual, contendo $20 \mathrm{~mL}$ de etanol ou metanol $(0,05$ de álcool $/ \mathrm{mL}$ recipiente). As um sementes foram distribuídas sobre um suporte, com pequenos orifícios em sua superfície e suspenso internamente ao recipiente, formando uma camada única, tomando toda a superfície do suporte, independentemente do número e do peso das sementes. O recipiente foi vedado com filme PVC e mantido a $28^{\circ} \mathrm{C}$ em câmara tipo B.O.D. (Biologic Oxygen Demand). As sementes permaneceram expostas ao vapor de álcool durante período de uma hora.

\subsubsection{Tratamento de sementes de feijão com ozônio}

O processo de ozonização das sementes de feijão foi realizado no Laboratório de PréProcessamento e Armazenamento da Faculdade de Agronomia e Medicina Veterinária, na Universidade de Brasília.

O gás ozônio foi obtido por meio de um gerador de ozônio (Modelo O\&L 3.0-O2 RM, da Ozone \& Life®) baseado no método de Descarga por Barreira Dielétrica. Este tipo de descarga é produzido ao aplicar uma alta tensão entre dois eletrodos paralelos, tendo entre eles um dielétrico (vidro) e um espaço livre por onde flui o ar seco. No espaço livre, é produzida uma descarga em forma de filamentos, em que são gerados elétrons com energia suficiente para produzir a quebra das moléculas de oxigênio, formando o ozônio $\left(\mathrm{O}_{3}\right)$. No processo de geração do ozônio, foi utilizado como insumo oxigênio $\left(\mathrm{O}_{2}\right)$, obtido de concentrador de oxigênio acoplado ao gerador de ozônio.

A concentração de ozônio foi determinada pelo método iodométrico, descrito por Clescerl et al., (2000). Esse método consiste no borbulhamento de massa gasosa contendo ozônio em $50 \mathrm{~mL}$ de solução de iodeto de potássio $(\mathrm{KI}) 1 \mathrm{~N}$, com produção de iodo $\left(\mathrm{I}_{2}\right)$. Para 
garantir o deslocamento da reação para a produção de $\mathrm{I}_{2}$, foi necessário acidificar o meio com 2,5 mL de ácido sulfúrico $\left(\mathrm{H}_{2} \mathrm{SO}_{4}\right) 1 \mathrm{~N}$, depois do borbulhamento. A solução foi titulada com tiossulfato de sódio $\left(\mathrm{Na}_{2} \mathrm{~S}_{2} \mathrm{O}_{3}\right)$ 0,01 N, com uso de solução de amido $1 \%$ como indicador.

Cada amostra de semente foi transferida para uma coluna de vidro, com capacidade de $500 \mathrm{~mL}$, tendo $19 \mathrm{~cm}$ de altura e $6 \mathrm{~cm}$ de diâmetro, e posteriormente foi adicionado $200 \mathrm{~mL}$ de água destilada e esterilizada. As colunas de vidro foram conectadas ao aparelho gerador de ozônio por meio de mangueiras de silicone. Instalou-se destruidor térmico catalítico depois da coluna de ozonização, necessária para decomposição do ozônio residual. Antes da ozonização das amostras, a coluna de vidro era sanitizada, com borbulhamento do próprio gás ozônio em água, por 5 minutos.

No processo de ozonização, adotou-se concentração de $28,0 \mathrm{mg} \cdot \mathrm{L}^{-1}$, com vazão do gás de $1,0 \mathrm{~L} \cdot \mathrm{min}^{-1}$, na temperatura de $25^{\circ} \mathrm{C}$, por 15 minutos.

\subsubsection{Avaliação da porcentagem de sementes contaminadas, quantificação de $C f f$ e eficiência dos tratamentos de sementes}

Para avaliação da incidência de sementes contaminadas e quantificação de $C f f$, tomaram-se amostras de 45 sementes para cada um dos sete tratamentos de sementes mais a testemunha, representada pelas sementes inoculadas e sem tratamento. Foi utilizado o delineamento inteiramente casualizado, com três repetições de 15 sementes.

As amostras foram submetidas ao processo de extração, onde as sementes são imersas em água. As sementes de cada tratamento foram colocadas individualmente em tubos de ensaio com $9 \mathrm{~mL}$ de água destilada esterilizada e incubadas em câmara fria por 18 horas à temperatura de $5^{\circ} \mathrm{C}$. Decorrido esse tempo, foi distribuído alíquotas de $100 \mu \mathrm{L}$ por placa, contendo meio de cultura 523 (Kado \& Heskett, 1970), com três placas por suspensão, 
totalizando 45 placas por repetição. Em seguida as placas foram incubadas a $28{ }^{\circ} \mathrm{C}$ por 72 horas.

A avaliação da porcentagem de sementes contaminadas foi feita observando-se a ausência ou presença de colônias típicas de Cff nas três placas. A semente foi considerada infectada quando apresentou, em pelo menos uma placa, uma colônia de Cff. Para quantificação de $C f f$, procedeu-se a contagem do número de colônias por placa, onde a valor de cada repetição foi obtido pela média do número de colônias nas 45 placas. Os resultados foram expressos em UFC/100 $\mu \mathrm{L}$ e posteriormente transformados em UFC/mL e UFC/semente. Calculou-se, ainda, a eficiência dos tratamentos de semente em porcentagem (E\%), por meio da relação entre a recuperação da bactéria, expressa em UFC a partir das amostras dos respectivos tratamentos e a amostra das sementes apenas inoculadas: $\mathrm{E} \%=(1-$ (UFC Tratamento/UFC Sem Tratamento))x100.

\subsubsection{Análises Estatísticas}

Os dados obtidos foram submetidos à análise de variância utilizando o programa SISVAR, versão 5.3 (Ferreira, 2008). As médias dos tratamentos foram comparadas pelo teste de Tukey a 5\% de probabilidade, de acordo com Banzatto \& Kronka, 2006.

\subsection{Experimento de Campo}

O experimento foi conduzido na Fazenda Piau, localizada no município de Unaí, MG, situada a $16^{\circ} 42^{\prime} 12^{\prime \prime}$ de latitude S e $49^{\circ} 44^{\prime} 51^{\prime \prime}$ de latitude $\mathrm{W}$, com altitude de $616 \mathrm{~m}$, entre os dias 5 e 18 de dezembro de 2013. Segundo Köppen-Geiger o clima local é classificado como Aw, tropical com inverno seco.

O solo do local é da classe Latossolo Vermelho Distrófico (Embrapa, 1999) cuja composição granulométrica na profundidade de 0 a $0,20 \mathrm{~m}$, é de $9 \%$ de areia, $28 \%$ de silte e 
$63 \%$ de argila. Os atributos químicos do solo, na mesma camada, antes da instalação do experimento, encontram-se na Tabela 2.3.

De acordo com os resultados da análise química do solo, realizou-se o cálculo da necessidade de calagem, empregando-se o método de elevação da saturação por bases.

O preparo de solo foi realizado através de duas gradagens pesadas e duas leves, sendo que a calagem foi realizada com a aplicação de $5000 \mathrm{~kg} \mathrm{ha}^{-1}$ de calcário dolomítico três meses antes da implantação do experimento.

Tabela 2.3. Atributos químicos na camada de 0 a 0,20 m do Latossolo Vermelho Distrófico da área experimental antes da instalação do ensaio, em Unaí - MG.

\begin{tabular}{|c|c|c|c|c|c|c|c|c|c|c|c|c|c|}
\hline \multirow{2}{*}{$\mathrm{pH}(\mathrm{H} 2 \mathrm{O})$} & $\mathrm{P}$ & $\mathrm{K}$ & $\mathrm{S}$ & $\mathrm{Ca}$ & $\mathrm{Mg}$ & $\mathrm{Al}$ & $\mathrm{H}+\mathrm{Al}$ & M.O & $\mathrm{B}$ & $\mathrm{Zn}$ & $\mathrm{Fe}$ & $\mathrm{Mn}$ & $\mathrm{Cu}$ \\
\hline & \multicolumn{3}{|c|}{---- mg.dm ${ }^{-3}$---- } & \multicolumn{4}{|c|}{------ $\mathrm{cmol}_{\mathrm{c}} \cdot \mathrm{dm}^{-3}$------- } & $--\%--$ & \multicolumn{5}{|c|}{------------ mg.dm" ${ }^{-3}$----------- } \\
\hline 4,8 & 1,6 & 103 & 4,7 & 0,8 & 0,7 & 1,4 & 8,9 & 4,4 & 0,3 & 1 & 46,6 & 49,5 & 0,6 \\
\hline
\end{tabular}

Análise realizada no Laboratório de Fertilidade de Solo e Nutrição Vegetal da CAMPO, Análises Agrícolas e Ambientais, Paracatu - MG.

O delineamento experimental utilizado foi o de blocos casualizados, em esquema fatorial 5x8, perfazendo 40 tratamentos, constituídos pela combinação de 5 tipos de amostras de sementes de feijão (semente básicas, com 10, 30 e 50\% de sementes inoculadas e sementes naturalmente infectadas) e 8 tratamentos de sementes (cobre, casugamicina, cloretos de benzalcônio, ácido peracético, vapor de etanol, vapor de metanol, ozônio e sem tratamento (testemunha)). Todos os tratamentos tiveram quatro repetições.

As sementes de feijão utilizadas no experimento pertencem a cultivar Pérola. A amostra com sementes básicas foi representada por sementes comprovadamente sadias (sem presença de $C f f)$, as quais também foram empregadas na mistura para a obtenção dos lotes com diferentes proporções de sementes inoculadas.

A inoculação das sementes foi realizada pelo método da imersão em suspensão bacterina, de acordo com o item 2.4.1. 
Os tratamentos de sementes foram realizados da mesma forma supracitada (itens 2.4.2 ao 2.4.4).

As sementes naturalmente infectadas com $C f f$ foram colhidas em uma lavoura comercial de feijão severamente atacada pela doença, localizada no município de Alto Paraíso, GO.

\subsubsection{Avaliação da emergência e velocidade de emergência de plântulas.}

A emergência das plântulas em campo foi realizada com subamostras de 120 sementes para cada tratamento e repetição. As parcelas foram constituídas por quatro linhas de 2,0 m de comprimento espaçadas de $0,50 \mathrm{~m}$ com 15 sementes por metro linear, distribuídas manualmente, a uma profundidade de aproximadamente $3,0 \mathrm{~cm}$.

Ao final do décimo segundo dia após a semeadura das sementes, quando não foi observada emergência de novas plântulas, avaliou-se a porcentagem de plântulas normais.

A velocidade de emergência campo foi conduzida em conjunto com o teste de emergência. As contagens do número de plântulas emergidas, ou seja, com os cotilédones completamente acima do nível do solo, foram realizadas diariamente, sem que estas fossem descartadas, obtendo-se, portanto, um valor cumulativo. Dessa maneira, o número de plântulas emergidas referentes a cada contagem foi obtido subtraindo-se do valor lido com o valor referente à leitura do dia anterior. Dessa forma, com o número de plântulas emergidas referentes a cada leitura, foi calculado o índice de velocidade de emergência (IVE) de acordo com (Maguire, 1962), empregando-se a seguinte fórmula:

$$
\text { IVE }=\frac{G_{1}}{N_{1}}+\frac{G_{2}}{N_{2}}+\cdots+\frac{G_{n}}{N_{n}} \text {, em que: }
$$


IVE = Índice de velocidade de emergência; $G$ = número de plântulas emergidas observadas em cada contagem; $\mathrm{N}$ = número de dias da semeadura a cada contagem.

Os dados climatológicos, referentes ao período de avaliação dos testes, estão apresentados na Tabela 2.4.

Tabela 2.4. Temperaturas máxima, mínima e compensada média, precipitação pluvial e umidade relativa do ar observadas ente os dias 5 e 12 de dezembro de 2013, em Unaí, Estado de Minas Gerais, na condução dos testes de emergência das plântulas e índice de velocidade de emergência em campo.

\begin{tabular}{|c|c|c|c|c|c|}
\hline \multirow[b]{2}{*}{ Dia/mês } & \multicolumn{3}{|c|}{ Temperatura } & \multirow[b]{2}{*}{$\begin{array}{l}\text { Precipitação } \\
\text { pluvial (mm) }\end{array}$} & \multirow[b]{2}{*}{$\begin{array}{l}\text { Umidade } \\
\text { relativa (\%) }\end{array}$} \\
\hline & Máxima $\left({ }^{\circ} \mathrm{C}\right)$ & Mínima $\left({ }^{\circ} \mathrm{C}\right)$ & $\begin{array}{l}\text { Compensada } \\
\text { média }\left({ }^{\circ} \mathrm{C}\right)\end{array}$ & & \\
\hline $05 / 12$ & 36,3 & 22,5 & 27,64 & 0 & 66,5 \\
\hline $06 / 12$ & 30,1 & 20,7 & 24,64 & 26,6 & 82,5 \\
\hline $07 / 12$ & 31,1 & 20,7 & 24,16 & 3,4 & 83,75 \\
\hline $08 / 12$ & 30,1 & 20,3 & 24,64 & 8,8 & 73,5 \\
\hline $09 / 12$ & 31,1 & 21,7 & 24,84 & 0,5 & 80,00 \\
\hline $10 / 12$ & 31,3 & 21,7 & 25,16 & 5,6 & 78,25 \\
\hline $11 / 12$ & 31,9 & 21,9 & 26,08 & 1,3 & 82,5 \\
\hline $12 / 12$ & 32,3 & 22,1 & 25,28 & 6,8 & 79,00 \\
\hline $13 / 12$ & 28,9 & 20,1 & 24,08 & 15,4 & 88,25 \\
\hline $14 / 12$ & 30,3 & 21,3 & 24,8 & 10,4 & 86,25 \\
\hline $15 / 12$ & 30,3 & 21,7 & 25,2 & 14,6 & 86,75 \\
\hline $16 / 12$ & 30,9 & 20,9 & 24,6 & 28,1 & 86,5 \\
\hline $17 / 12$ & 32,3 & 22,1 & 25,28 & 29,2 & 76,00 \\
\hline $18 / 12$ & 31,7 & 22,3 & 25,16 & 0 & 77,75 \\
\hline
\end{tabular}

Fonte: Estação Meteorológica de Unaí - MG, INMET. 


\subsubsection{Análises estatísticas}

Os dados obtidos foram submetidos à análise de variância utilizando o programa SISVAR, versão 5.3 (Ferreira, 2008). As médias dos tratamentos foram comparadas pelo teste de Tukey a 5\% de probabilidade, de acordo com Banzatto \& Kronka, 2006.

\subsection{Experimento em Casa de Vegetação}

O experimento foi desenvolvido em casa de vegetação da Estação Experimental de Biologia da Universidade de Brasília, localizada em Brasília, DF, 1544'5" de latitude S e 4753'1" de longitude W.

O experimento teve início com a semeadura no dia 17/04/2014 e o fim com a colheita no dia 17/07/2014, totalizando um ciclo de 90 dias. Durante a condução do experimento foi mantido um termohigrógrafo (Data Logger ${ }^{\circledR}$ ) o qual registrou temperatura variando de $15^{\circ} \mathrm{C}$ a $36{ }^{\circ} \mathrm{C}$ e umidade relativa de $34 \%$ a $98 \%$.

Foram utilizadas sementes de feijão (Phaseolus vulgaris L.), cultivar Pérola, comprovadamente sadias (sementes básicas). Para inoculação das sementes, foi utilizado o método de imersão em suspensão bacteriana supracitado no item 2.4.1.

Os tratamentos de sementes foram realizados da mesma forma descrita anteriormente (itens: 2.4 .2 ao 2.4 .4 ).

O delineamento experimental utilizado foi o de blocos casualizados, em esquema fatorial 2x8, perfazendo 16 tratamentos, constituídos pela combinação de 2 amostras de sementes de feijão (sementes básicas e sementes inoculadas) e 8 tratamentos de sementes (cobre, casugamicina, cloretos de benzalcônio, ácido peracético, vapor de etanol, vapor de metanol, ozônio e sem tratamento (testemunha)). Cada parcela foi constituída por quatro vasos com seis sementes cada, totalizando vinte e quatro sementes por repetição. Todos os tratamentos tiveram quatro repetições. 
As sementes foram plantadas em vasos, contendo o volume de aproximado 3,0L de substrato previamente autoclavado. O substrato foi composto por Latossolo Vermelho enriquecido com adubo formulado (NPK 4-14-8, 0,5 Kg.m ${ }^{-3}$ ). A profundidade de semeadura foi de aproximadamente $3,0 \mathrm{~cm}$.

Aos quinze dias após a semeadura (15 DAS) realizou-se o desbaste deixando três plantas por vaso, perfazendo um total de doze plantas por parcela.

Irrigações foram realizadas de acordo com a necessidade hídrica da cultura. Aplicações alternadas com imidacloprido e tiametoxan foram realizadas visando o controle da mosca branca (Bemisia tabaci Genn.).

As avaliações realizadas foram: emergência e índice de velocidade de emergência de plântulas, desenvolvimento vegetativo, incidência e severidade da Murcha de Curtobacterium e produção de grãos.

\subsubsection{Avaliação da emergência e velocidade de emergência de plântulas}

A avaliação emergência de plântulas em casa de vegetação foi realizada com amostras de 24 sementes para cada tratamento e repetição, distribuídas igualmente em quatro repetições.

Ao final do décimo segundo dia após a semeadura das sementes, quando não foi observada emergência de novas plântulas, avaliou-se a porcentagem de plântulas normais. A velocidade de emergência campo foi conduzida em conjunto com o teste de emergência, contabilizando, do $5^{\circ}$ ao $12^{\circ}$ dias após a semeadura o número de plântulas que apresentavam os cotilédones acima da superfície do solo. Ao final do teste foi calculado o IVE, empregando-se a fórmula proposta por Maguire (1962). 


\subsubsection{Avaliação do Desenvolvimento Vegetativo}

O desenvolvimento vegetativo do feijoeiro foi avaliado determinando-se o peso de matéria verde de parte aérea, número de trifólios e altura da planta.

Para avaliação do peso de matéria verde, quatro plantas por parcela, oriundas do desbaste realizado aos quinze dias após a semeadura, foram selecionadas ao acaso. As plantas foram colocadas em sacos plásticos e levadas ao laboratório, onde foram pesadas em balança com precisão de $0,01 \mathrm{~g}$. Os dados foram expressos em g.planta ${ }^{-1}$.

As avaliações do número de trifólios e a altura da planta foram realizadas aos vinte e oito dias após a semeadura (28 DAS). Para o número de trifólios foi contabilizado, nas 12 plantas de cada parcela, o total de folhas trifolioladas completamente expandidas.

A altura de planta foi medida com auxilio de uma régua graduada em centímetros, medindo-se a partir do nível do solo no vaso até o quarto nó da haste principal. Foram medidas as 12 plantas de cada parcela.

\subsubsection{Avaliação da incidência e severidade da Murcha de Curtobacterium}

As avaliações de incidência e severidade da Murcha de Curtobacterium foram realizadas aos 30, 45 e 60 dias após a semeadura. A incidência da doença foi avaliada contando-se o número de plantas com sintomas típicos causados por Cff em cada parcela. Os sintomas da doença foram avaliados em todas as plantas de cada parcela, com o emprego de uma escala de notas que variaram de 0 a 9, conforme Maringoni, 2000, onde: $0=$ sem sintomas da doença; 1 = sintomas de clorose nas folhas; 3 = poucas folhas murchas $(1$ a 3 folhas, menos de $10 \%$ das folhas da planta); 5 = aproximadamente $25 \%$ de folhas apresentam murchas e amarelecimento; $7=$ aproximadamente $50 \%$ de folhas murchas, amarelecimento e necrose de folíolos, plantas com nanismo; 9 = aproximadamente $75 \%$ ou mais de folhas com 
murcha e/ ou necrose, queda prematura de folhas, nanismo severo e/ou morte da planta. A severidade para cada tratamento foi obtida pela média dos valores obtidos nas parcelas.

A partir dos valores de severidade obtidos, foi calculada a área abaixo da curva de progresso da Murcha de Curtobacterium para cada tratamento, de acordo com a fórmula:

$$
\mathrm{AACPMC}=\Sigma\{[(\mathrm{Y} 1+\mathrm{Y} 2) / 2] * \Delta \mathrm{t}\}
$$

onde Y1 e Y2 corresponderam aos valores de severidade para duas avaliações sucessivas dentro da mesma parcela e $\Delta \mathrm{t}$, o intervalo de tempo entre elas.

Para análises dos dados de incidência, severidade e AACPMC foi considerado o delineamento experimental blocos ao acaso sem arranjo fatorial, pois as plantas oriundas de sementes não inoculadas com $C f f$ não apresentaram sintomas característicos da doença. Correspondendo assim a oito tratamentos, sendo a testemunha representada pelas plantas oriundas de sementes inoculadas sem tratamento de sementes.

\subsubsection{Avaliação da produção}

A colheita foi realizada, quando todas as plantas do experimento atingiram o estádio fenológico R9, no dia 17/07/2014. As vagens presentes em cada parcela foram colhidas manualmente e colocadas em sacos plásticos devidamente identificados.

Após a colheita as vagens foram levadas ao laboratório para contagem e debulha. Em seguida, foram avaliados os seguintes parâmetros produtivos: número de vagens por parcela (NVT), número de grãos por parcela (NGT), número de grãos por vagem (NGV), número de grãos abortados por vagem (NAV), porcentagem de grãos abortados (PSA), peso de grãos por parcela (PGT), e número de grãos por grama (NGG). 


\subsubsection{Análises estatísticas}

Os dados obtidos foram submetidos à análise de variância utilizando o programa SISVAR, versão 5.3 (Ferreira, 2008). As médias dos tratamentos foram comparadas pelo teste de Tukey a 5\% de probabilidade, de acordo com Banzatto \& Kronka, 2006.

\subsection{Taxa de transmissão planta - semente}

Para determinar a taxa de transmissão de Cff das plantas para as sementes, foi selecionada uma amostra de 80 sementes, provenientes das parcelas com plantas oriundas de sementes inoculadas e não tratatadas. Posteriormente a amostra foi subdividida em quatro subamostras de 20 sementes cada.

Para a extração da bactéria, cada semente foi individualmente embrulhada em papel alumínio previamente autoclavado e triturada com auxilio de um alicate tipo "universal". Os fragmentos de cada semente foram imersos em tubo de ensaio contento $9 \mathrm{~mL}$ de água destilada esterilizada. Os tubos foram fechados com tampões de algodão, incubados a $5{ }^{\circ} \mathrm{C}$ por $18 \mathrm{~h}$ e, posteriormente, agitados manualmente. Decorrido esse tempo, retirou-se uma alíquota de $100 \mu \mathrm{L}$ a qual foi depositada e espalhada, com auxilio de uma alça de Drigalski flambada, sobre o meio 523 (Kado \& Heskett, 1970).

Para cada suspensão obtida foram realizadas três repetições, de uma placa cada, perfazendo um total de 60 placas por subamostra. As placas foram incubadas a $28{ }^{\circ} \mathrm{C}$, por 72 h e foi observada a presença ou não de colônias típicas de $C f f$. Para confirmação da identidade do microrganismo isolado, foi realizado teste de coloração de Gram e hidróxido de potássio (KOH 3\%).

A semente foi considerada infectada quando apresentou em pelo menos uma placa uma colônia de $C f f$. O resultado final foi expresso em porcentagem, obtido a partir da média das quatro subamostras. 


\section{RESULTADOS E DISCUSSÃO}

\subsection{Isolado de Curtobacterium flaccumfaciens pv. flaccumfaciens (Cff)}

A partir dos isolamentos em meio de cultura 523 (Kado \& Heskett, 1970), obteve-se colônias de formato circular, bordos lisos, aspecto brilhante, levemente convexas, amarelas a bege opaco. As características apresentadas pela bactéria reisolada foram: células em forma de bastonete, Gram positiva e não solúvel em KOH a $3 \%$.

\subsection{Patogenicidade e reação de hipersensibilidade do isolado de $C f f$}

O isolado UnB 1376 foi patogênico as plantas de feijoeiro, induzindo sintomas característicos da doença como murcha, flacidez, amarelecimento das folhas, queima ou encarquilhamento do bordo foliar, escurecimento vascular e nanismo. A reação de hipersensibilidade em folhas de fumo foram todas positivas.

\subsection{Sensibilidade "in vitro" de $C f f$ a diferentes produtos fitossanitários}

Todos os produtos utilizados neste estudo reduziram o número de colônias bacterianas com o aumento da concentração do produto em meio de cultura, quando comparado à testemunha.

Para os produtos cúpricos, as concentrações de cobre metálico que inibiram o crescimento de $C f f$ variaram de 20 a $50 \mu \mathrm{g} / \mathrm{ml}$ (Tabela 3.1). Os princípios ativos sulfato de cobre e óxido cuproso foram os que inibiram o crescimento da bactéria em menor concentração $(20 \mu \mathrm{g} / \mathrm{ml})$ e o oxicloreto de cobre em maior concentração $(50 \mu \mathrm{g} / \mathrm{ml})$.

As células procariontes e eucariontes requerem cobre para seu crescimento normal, pois é constituinte de diversas enzimas, tais como as oxigenases e as envolvidas no transporte de elétrons, ambas envolvidas na respiração. Mas em determinadas concentrações, o cobre 
têm a habilidade de gerar radicais livres capazes de danificar o DNA e membranas lipídicas, sendo tóxico às células (Valoudakis et al., 2005).

Uesugi et al. (2005) avaliando a sensibilidade "in vitro" de cinco isolados de Cff ao cobre, verificaram que ao utilizar sulfato de cobre os isolados cresceram até a concentração de $400 \mu \mathrm{g} / \mathrm{mL}$ em meio de cultura 523 e $40 \mu \mathrm{g} / \mathrm{mL}$ em meio MMCC, com exceção para um isolado (UnB 1284) que cresceu até 100 e $20 \mu \mathrm{g} / \mathrm{mL}$ em meio 523 e MMCC respectivamente, utilizando oxicloreto de cobre houve crescimento até $500 \mu \mathrm{g} / \mathrm{mL}$ no meio 523 e até $50 \mu \mathrm{g} / \mathrm{mL}$ no MMCC. Já para hidróxido de cobre, houve crescimento até $800 \mu \mathrm{g} / \mathrm{mL}$ no meio 523 e no meio MMCC até $100 \mu \mathrm{g} / \mathrm{mL}$. O sulfato de cobre mostrou melhor eficiência na inibição do crescimento bacteriano, fato também observado no presente estudo.

Costa et al. (2012) caracterizaram 44 isolados de Xanthomonas spp., causadores da mancha bacteriana do tomateiro para consumo in natura, provenientes da região do Alto Vale do Rio do Peixe, SC, Brasil, quanto a sensibilidade ao cobre utilizando o meio CYE-glycerol suplementado com sulfato de cobre nas concentrações de 50, 100 e $200 \mu \mathrm{g} / \mathrm{mL}$ e verificaram que $98 \%$ de todos os isolados foram sensíveis a $200 \mu \mathrm{g} / \mathrm{mL}$, sugerindo que aparentemente, a dosagem recomendada de produtos à base de cobre em campo, 10 vezes maior que a dosagem limítrofe utilizada nos testes in vitro, ainda é eficiente para as diferentes espécies da bactéria.

Meneguin et al. (2007) determinando a sensibilidade ao cobre de 122 isolados Xanthomonas axonopodis pv. citri (Xac), causador do cancro cítrico, utilizando o meio AN suplementado com sulfato de cobre nas concentrações $0,1,5,10,20,50$ e $100 \mu \mathrm{g} / \mathrm{mL}$, observaram que a maior concentração de cobre em que foi observado crescimento de isolados de $X a c$ foi de $50 \mu \mathrm{g} / \mathrm{mL}$. Entretanto $45,5 \%$ dos isolados da bactéria provenientes de pomares que receberam aplicações frequentes de cobre cresceram na presença de $50 \mu \mathrm{g} / \mathrm{mL}$ de cobre, contra apenas $13,4 \%$ dos isolados oriundos de pomares que não receberam pulverizações regulares do bactericida. 
Marques et al. (2009) avaliaram a sensibilidade ao cobre de estirpes de Xanthomonas campestris pv. viticola, causador do cancro bacteriano em videira, coletadas em diferentes localidades, entre os anos de 1998 a 2006 e observaram variabilidade na sensibilidade ao oxicloreto de cobre e ao sulfato de cobre entre as 21 estirpes testadas, onde a concentração mínima inibitória variou entre 10 e $60 \mu \mathrm{g} / \mathrm{mL}$ de $\mathrm{Cu}^{2+}$, para os dois produtos. De forma geral foi observado pelos autores uma evolução no crescimento da tolerância ao cobre ao longo dos anos, com as estirpes brasileiras.

Diversos produtos cúpricos têm sido utilizados no controle de doenças bacterianas. $\mathrm{O}$ cobre atua na proteção do tecido vegetal contra infecção por bactérias e na redução da população bacteriana na superfície foliar. Entretanto, são necessárias várias aplicações de produtos para alcançar controle adequado de doenças bacterianas (Leite Júnior, 2000). No entanto o uso prolongado de bactericidas cúpricos para o controle de fitobacterioses pode também levar ao surgimento de linhagens da bactéria resistentes ao cobre. Resistência a cúpricos já foi reportada para bactérias fitopatogênicas dos gêneros Pseudomonas (Cooksey, 1990; Nakajima et al., 2002 e Silva \& Lopes, 1995) e Xanthomonas (Marco \& Stall, 1983; Aguiar et al., 2000 e Quezado - Duval et al., 2003).

Tabela 3.1. Porcentagem do número médio de colônias de Curtobacterium flaccumfaciens pv. flaccumfaciens observado em meio CYE-glycerol contendo produtos cúpricos em diferentes concentrações em relação ao meio sem cobre. UnB, Brasília, DF, 2015.

\begin{tabular}{|c|c|c|c|c|c|c|c|}
\hline \multirow{2}{*}{ Princípio Ativo } & \multicolumn{7}{|c|}{ Concentração $\mathrm{Cu}^{++}(\mu \mathrm{g} / \mathrm{mL})$} \\
\hline & 10 & 20 & 30 & 40 & 50 & 100 & 200 \\
\hline Hidróxido de Cobre & 81 & 69 & 0 & 0 & 0 & 0 & 0 \\
\hline Oxicloreto de Cobre & 98 & 42 & 12 & 4 & 0 & 0 & 0 \\
\hline Óxido Cuproso & 73 & 0 & 0 & 0 & 0 & 0 & 0 \\
\hline Sulfato de Cobre & 80 & 0 & 0 & 0 & 0 & 0 & 0 \\
\hline
\end{tabular}


A casugamicina inibiu o crescimento de $C f f$ a partir da concentração de $100 \mu \mathrm{g} / \mathrm{mL}$ do principio ativo em meio de cultura (Tabela 3.2).

Tayler \& Dudley (1977) estudando a atividade "in vitro" de casugamicina e estreptomicina contra dois isolados de Pseudomonas phaseolicola $(=P$. savastanoi pv. phaseolicola), observou que a partir da concentração de $100 \mu \mathrm{g} / \mathrm{mL}$, de ambos princípios ativos, não houve crescimento bacteriano e presença de células viáveis em meio de cultura.

Mello et al. (2011) avaliando a sensibilidade "in vitro" de seis isolados de Pectobacterium carotovorum subsp. carotovorum aos bactericidas Agri-Micina ${ }^{\circledR}$ (Pfizer ${ }^{\circledR}$, oxitetraciclina, 1,5\%; sulfato de estreptomicina, 15\%), Kasumin ${ }^{\circledR}$ (Arysta Lifescience ${ }^{\circledR}$, casugamicina 2,0\%) e Mycoshield $\AA$ (Pfizer $\AA$, oxitetraciclina, 20\%), nas dosagens recomendadas para hortaliças, respectivamente $3,0 \mathrm{~g}, 2,0 \mathrm{~mL}$ e $3,0 \mathrm{~g}$ de produto comercial $\mathrm{L}^{-1}$ de água, observaram que todos os isolados foram resistentes a casugamicina e sensíveis para os outros bactericidas.

Tabela 3.2. Número de colônias (UFC/mL) de Curtobacterium flaccumfaciens pv. flaccumfaciens em meio de cultura 523 suplementado com casugamicina em diferentes concentrações. UnB, Brasília, DF, 2015.

\begin{tabular}{cccccccccc}
\hline \multirow{2}{*}{ Princípio Ativo } & \multicolumn{10}{c}{ Concentração $(\mu \mathrm{g} / \mathrm{mL})$} \\
\cline { 2 - 11 } & 0 & 1 & 5 & 10 & 20 & 25 & 50 & 100 & 200 \\
\cline { 2 - 11 } Casugamicina & 1000 & 904 & 848 & 828 & 824 & 804 & 180 & 0 & 0 \\
\hline
\end{tabular}

O princípio ativo constituído à base de cloretos de benzalcônio inibiu o crescimento de Cff a partir da concentração de $20 \mu \mathrm{g} / \mathrm{mL}$ em meio de cultura (Tabela 3.3).

Rezende (2006) avaliando a sensibilidade de cinco isolados de Erwinia psidii a diferentes formulações cúpricas e aos cloretos de benzalcônio, verificou que utilizando sulfato de cobre, os isolados cresceram até a concentração de $300 \mu \mathrm{g} / \mathrm{mL}$ em meio de cultura 523 e $30 \mu \mathrm{g} / \mathrm{mL}$ em meio MMCC, oxicloreto de cobre, houve crescimento até $300 \mu \mathrm{g} / \mathrm{mL}$ no meio 
523 e até $50 \mu \mathrm{g} / \mathrm{mL}$ no MMCC, e hidróxido de cobre, observou crescimento até $400 \mu \mathrm{g} / \mathrm{mL}$ no meio 523 e no meio MMCC até $100 \mu \mathrm{g} / \mathrm{mL}$. Já para os cloretos de benzalcônio, houve crescimento até $80 \mu \mathrm{g} / \mathrm{mL}$, não havendo diferença entre os meios de cultura utilizados. Estes resultados mostraram que os cloretos de benzalcônio foram mais eficientes no controle de $E$. psidii "in vitro", quando comparado aos produtos cúpricos.

Trabalho realizado por Abreu et al. (2008) com objetivo de avaliar o efeito "in vitro" de sanificantes no controle de fungos causadores de podridões pós colheita em pêssegos, os autores verificaram que os cloretos de benzalcônio e a biomassa cítrica, ambos na concentração de $1000 \mu \mathrm{L} \mathrm{L}^{-1}$, inibiram totalmente o crescimento radial (micelial) de Monilinia fructicola, porém nenhum deles foi eficiente no controle de Rhizopus stolonifer.

Tabela 3.3. Número de colônias (UFC/mL) de Curtobacterium flaccumfaciens pv. flaccumfaciens em meio de cultura 523 suplementado com cloretos de benzalcônio em diferentes concentrações. UnB, Brasília, DF, 2015.

\begin{tabular}{lcccccccc}
\hline \multirow{2}{*}{ Princípio Ativo } & \multicolumn{7}{c}{ Concentração $(\mu \mathrm{g} / \mathrm{mL})$} \\
\cline { 2 - 9 } & 0 & 20 & 40 & 60 & 80 & 100 & 200 \\
\cline { 2 - 9 } Cloretos de benzalcônio & 1184 & 0 & 0 & 0 & 0 & 0 & 0 \\
\hline
\end{tabular}

O ácido paracético inibiu o crescimento de Cff a partir da concentração de $200 \mu \mathrm{g} / \mathrm{mL}$ do princípio ativo em meio de cultura (Tabela 3.4).

O ácido peracético, também chamado de peróxido de ácido acético ou ácido peroxiacético é um agente sanitizante que tem sido utilizado com bastante sucesso, principalmente nos EUA. É obtido pela reação do ácido acético ou anidrido acético com o peróxido de hidrogênio (Nascimento, 2002; Srebernich, 2007). Trata-se de um excelente sanitizante pela grande capacidade de oxidação dos componentes celulares dos microrganismos, tendo uma rápida ação a baixas concentrações sobre um amplo espectro de microrganismos. É esporicida em baixas temperaturas e continua efetivo na presença de 
material orgânico sendo, portanto, um biocida efetivo sem residual tóxico. Sua ação biocida é influenciada pela concentração, temperatura e tipo de microrganismos (Block, 1991).

Frare (2010) avaliou a eficiência de 60 produtos fitossanitários comerciais mais o ácido peracético no controle "in vitro" de quatro isolados de Acidovorax avenae subsp. citulli. Os antibióticos casugamicina (100 e $200 \mu \mathrm{g} / \mathrm{mL})$, oxitetraciclina (10, 100 e $200 \mu \mathrm{g} / \mathrm{mL})$, oxitetraciclina+sulfato de cobre $(10,100$ e $200 \mu \mathrm{g} / \mathrm{mL})$, os fungicidas captana, carboxina + tiram, cloretos de benzalcônio, mancozebe + oxicloreto de cobre, metiram, metiram + piraclostrobina e tebuconnazol, nas doses de 100 e $200 \mu \mathrm{g} / \mathrm{mL}$ e o ácido peracético a partir da dose de $300 \mu \mathrm{g} / \mathrm{mL}$ apresentaram resultados satisfatórios.

Não existem produtos registrados junto ao Ministério da Agricultura Pecuária e Abastecimento (MAPA) para o controle da Murcha de Curtobacterium (AGROFIT, 2014). O controle químico para esta doença ainda não é uma opção presente, provavelmente devido a este fato o isolado de Curtobacterium flaccumfaciens pv. flaccumfaciens, utilizado neste estudo, não apresentou resistência aos princípios ativos testados.

Tabela 3.4. Número de colônias (UFC/mL) de Curtobacterium flaccumefaciens pv. flaccumefaciens em meio de cultura 523 suplementado com ácido peracético em diferentes concentrações. UnB, Brasília, DF, 2015.

\begin{tabular}{lccccccccc}
\hline Princípio Ativo & \multicolumn{8}{c}{ Concentração $(\boldsymbol{\mu g} / \mathbf{m L})$} \\
\cline { 2 - 10 } & 0 & 100 & 200 & 300 & 400 & 500 & 1000 & 1500 & 2000 \\
\cline { 2 - 9 } & 992 & 896 & 0 & 0 & 0 & 0 & 0 & 0 & 0 \\
\hline
\end{tabular}

\subsection{Efeito de diferentes tratamentos de sementes na erradicação de $C f f$}

Após inoculação das sementes de feijão, em suspensão bacteriana durante 30 minutos, obteve-se $100 \%$ de sementes contamindas, das quais, $82,22 \%$ com colonização interna (Tabela 3.5). Theodoro et al., 2011, verificaram que após a inoculação de sementes de algodoeiro com Xanthomonas axonopodis pv. malvacearum através da imersão em suspensão 
bacteriana durantes 3 horas, $100 \%$ das sementes foram infectadas, mas em campo não foi verificado transmissão da bactéria presente nas sementes para as plântulas .

Deunner (2007) utilizando a técnica de condicionamento fisiológico, expondo as sementes de feijão, por 48 horas, a Cff em meio de cultura 523 com restritor hídrico manitol no potencial hídrico de $-0,95 \mathrm{MPa}$, obteve $100 \%$ de sementes contaminadas externamente e internamente. Este método de inoculação não afetou a germinação das sementes e possibilitou a transmissão da bactéria das sementes para as plântulas.

Tabela 3.5. Número e localização de colônias de Curtobacterium flaccumfaciens pv. flaccumfaciens em sementes de feijão inoculadas por meio do método da imersão em suspensão bacteriana. UnB, Brasília, DF, 2015.

\begin{tabular}{|c|c|c|}
\hline & Incidência (\%) & Número de colônias \\
\hline Interna $^{1}$ & 82,22 & 76,84 \\
\hline Interna + Externa $^{2}$ & 100 & 196,02 \\
\hline
\end{tabular}

${ }^{1}$ Com desinfestação superficial; ${ }^{2}$ Sem desinfestação superficial.

Todos os tratamentos de sementes reduziram significativamente à incidência de sementes contaminadas com Cff, em relação à testemunha (sem tratamento). Os melhores tratamentos foram exposição a vapor de metanol e imersão em solução de cloretos de benzalcônio, os quais reduziram a incidência em 80 e 75,55\% respectivamente. Os tratamentos com ozônio e vapor de etanol foram os que menos reduziram a incidência de sementes contaminadas, os quais não diferiram estatisticamente do tratamento com ácido peracético. Os tratamentos com ozônio e vapor de etanol reduziram a incidência de sementes contaminadas em apenas 17,88 e $20 \%$ respectivamente (Tabela 3.6). 
Tabela 3.6. Porcentagem de sementes feijão inoculadas com Curtobacterium flaccumfaciens pv. flaccumfaciens com a presença do patógeno, após diferentes tratamentos. UnB, Brasília, DF, 2015.

\begin{tabular}{ccc}
\hline Tratamentos & Incidência (\%) & Porcentagem de eliminação (\%) \\
\hline Cobre & $42,22 \mathrm{~d}$ & 57,78 \\
Casugamicina & $57,78 \mathrm{c}$ & 42,22 \\
Ácido Peracético & $68,89 \mathrm{bc}$ & 31,11 \\
Cloretos de Benzalcônio & $24,45 \mathrm{e}$ & 75,55 \\
Vapor Etanol & $80,00 \mathrm{~b}$ & 20,00 \\
Vapor Metanol & $20,00 \mathrm{e}$ & 80,00 \\
Ozônio & $82,22 \mathrm{~b}$ & 17,78 \\
Sem Tratamento & $100,00 \mathrm{a}$ & -- \\
\hline CV (\%) & 8,57 & \\
\hline
\end{tabular}

Valores seguidos pelas mesmas letras não diferem entre si a 5\% de probabilidade pelo teste de Tukey. DMS = 14,40 .

Através da quantificação de $C f f$ presente nas sementes, verificou-se que todos os tratamentos reduziram significativamente o número de células bacterinas, em relação à testemunha, mas nenhum erradicou completamente a bactéria. Os tratamentos das sementes mediante a exposição vapor de metanol e imersão em solução de cloretos de benzalcônio foram os que apresentaram os melhores resultados. A eficiência destes tratamentos foi de aproximadamente de $99,2 \%$, ou seja, apenas $0,8 \%$ das células bacterianas resistiram a estes tratamentos. O tratamento com ozônio foi menos eficiente, onde a redução do número de células viáveis foi de $78,6 \%$. Os tratamentos com cobre, casugamicina, ácido paracético e vapor de etanol não diferiram estatisticamente entre si Tabela (3.7).

Taylor \& Dudley (1977) avaliando a eficiência de antibióticos, em diferentes formulações, no controle do controle do crestamento bacteriano aureolado, observaram que os tratamentos com pastas de estreptomicina (2,5 g i.a./ $\mathrm{kg}$ de semente) ou casugamicina $(0,25 \mathrm{~g}$ i.a./ $\mathrm{kg}$ de semente) foram eficientes na redução do número de células bacterianas em 
sementes naturalmente infectadas ou inoculadas, com Pseudomonas phaseolicola (=P. savastanoi pv. phaseolicola), além de não serem fitotóxicos.

Estefani et al. (2007) avaliando o efeito da termo e quimioterapia na erradicação de Cff e sobre a qualidade fisiológica em sementes de feijão (Phaseolus vulgaris L.), cultivar Pérola, verificaram que o tratamento das sementes por imersão em solução de Agrimaicin $500^{\circledR}$ (sulfato de cobre, $500 \mathrm{~g}+$ oxitetraciclina, $30 \mathrm{~g} / \mathrm{kg}$ do produto) na concentração de 10 g/L de água, durante 2 horas, eliminou a bactéria de sementes naturalmente infectadas, no entanto, em sementes inoculadas por imersão em suspensão $\left(10^{8} \mathrm{UFC} / \mathrm{mL}\right)$ o tratamento não foi efetivo, já o tratamento onde as sementes foram embebidas por 2 horas em água e tratadas a $60{ }^{\circ} \mathrm{C}$ durante 3 horas reduziu significativamente o número de células de $C f f$ em sementes inoculadas e eliminou a bactéria em sementes naturalmente infectadas. Entretanto estes tratamentos afetaram significativamente a qualidade fisiológica das sementes de feijão.

Hopkins et al. (2003) verificaram que o tratamento de sementes por imersão em solução de ácido peracético a $1600 \mu \mathrm{g} / \mathrm{mL}$, seguido de secagem em estufa a $40{ }^{\circ} \mathrm{C}$, por 48 horas, foi eficaz em erradicar Acidovorax avenae subsp. citrulli em sementes contaminadas . Entretanto a utilização de ácido clorídrico a $10000 \mu \mathrm{g} / \mathrm{mL}$, embora tenha sido eficiente na eliminação do patógeno afetou significativamente a germinação das sementes.

Carmo et al. (2004) comparando a eficiência de tratamentos físicos e químicos na erradicação de Xanthomonas vesicatoria em sementes de tomate cultivar 'Santa Clara Miss Brasil' verificaram que tratamento com ácido clorídrico $(\mathrm{HCl})$ a 5\% durante 10 minutos foi eficiente na erradicação e o tratamento com calor seco $\left(70{ }^{\circ} \mathrm{C} / 96\right.$ horas $)$ reduziu significativamente a população da bactéria, mas os tratamentos por imersão em água a $50{ }^{\circ} \mathrm{C}$ por 25 e 30 minutos não foram eficientes na erradicação ou redução do número de células bacterianas. 
Alencar (2009) avaliando a eficácia do ozônio como agente fungicida em amendoim (Arachis hypogaea L.), observou que grãos expostos ao gás ozônio na concentração de $21 \mathrm{mg}$ $\mathrm{L}^{-1}$ durante 96 horas foi eficiente no controle de fungos totais e de espécies potencialmente aflatoxigênicas (Aspergillus flavus e A. parasiticus), com redução superior a três ciclos log na contagem dos microrganismos. Em contrapartida Silva (2011) observou que o gás ozônio no binômio (0,54 mg L $\left.\mathrm{m}^{-1} \times 100 \mathrm{~h}\right)$ não apresentou efeito fungicida em grãos de trigo, pois não houve redução significativa de esporos de Penicillium spp. nas amostras tratadas.

Tabela 3.7. Número de colônias em sementes de feijão inoculadas com Curtobacterium flaccumfaciens pv. flaccumfaciens, após diferentes tratamentos. UnB, Brasília, DF, 2015.

\begin{tabular}{ccccc}
\hline Tratamentos & UFC/100 $\mu \mathbf{L}$ & UFC/mL & UFC/semente & Eficiência (\%)* \\
\hline Cobre & $22,73 \mathrm{c}$ & $227,3 \mathrm{c}$ & $2045,4 \mathrm{c}$ & 88,41 \\
Casugamicina & $25,71 \mathrm{c}$ & $257,1 \mathrm{c}$ & $2313,6 \mathrm{c}$ & 86,89 \\
Ácido Peracético & $26,18 \mathrm{c}$ & $261,8 \mathrm{c}$ & $2355,9 \mathrm{c}$ & 86,65 \\
$\begin{array}{c}\text { Cloretos de } \\
\text { Benzalcônio }\end{array}$ & $1,50 \mathrm{~d}$ & $15,0 \mathrm{~d}$ & $135,3 \mathrm{~d}$ & 99,23 \\
Vapor Etanol & $26,66 \mathrm{c}$ & $266,6 \mathrm{c}$ & $2399,4 \mathrm{c}$ & 86,40 \\
Vapor Metanol & $1,49 \mathrm{~d}$ & $14,9 \mathrm{~d}$ & $134,1 \mathrm{~d}$ & 99,24 \\
Ozônio & $41,93 \mathrm{~b}$ & $419,3 \mathrm{~b}$ & $3774,0 \mathrm{~b}$ & 78,61 \\
Sem Tratamento & $196,02 \mathrm{a}$ & $1960,2 \mathrm{a}$ & $17642,1 \mathrm{a}$ & -- \\
\hline
\end{tabular}

$\mathrm{CV}(\%)$

Valores seguidos pelas mesmas letras não diferem entre si a 5\% de probabilidade pelo teste de Tukey. *Eficiência $(\%)=\left(1-\left(\mathrm{UFC}\right.\right.$ Tratamento/UFC Sem Tratamento))x100. DMS $\mathrm{UFC} / 100 \mu \mathrm{L}_{1}=12,53 ; \mathrm{DMS}_{\mathrm{UFC} / \mathrm{mL}}=125,30$; $\mathrm{DMS}_{\mathrm{UFC} / \mathrm{semente}}=1128$. 


\subsection{Experimento de Campo}

\subsubsection{Emergência e velocidade de emergência de plântulas.}

O desdobramento da interação entre amostra de sementes e tratamento de sementes para emergência de plântulas em campo encontra-se apresentado na Tabela 3.8. Dentro da cada amostra de sementes (sementes básicas, com 10, 30 e 50\% de sementes inoculadas e sementes naturalmente infectadas), nenhum tratamento promoveu incremento na emergência de plântulas. Os tratamentos com ozônio e ácido peracético afetaram negativamente a emergência, pois estes tratamentos foram estatisticamente inferiores quando comparados com a testemunha (sem tratamento).

Dentro das amostras com sementes básicas e com 10 e $30 \%$ de sementes inoculadas, o tratamento com ozônio não diferiu do tratamento com ácido peracético e metanol. Na amostra com sementes básicas o tratamento com ácido paracético não diferiu dos tratamentos com vapor de metanol, casugamicina, cloretos de benzalcônio e cobre. Na amostra com $10 \%$ de sementes inoculadas, o tratamento com ácido peracético não diferiu dos tratamentos com vapor de metanol e casugamicina. Já nas amostras com $30 \%$ de sementes inoculas o tratamento com ácido paracético não diferiu dos tratamentos com vapor de metanol, casugamicina, vapor de etanol e cobre.

Dentro da amostra com $50 \%$ de sementes inoculadas o tratamento com ozônio não diferiu do tratamento com ácido peracético. Já o tratamento com ácido peracético não diferiu do tratamento com metanol.

Dentro da amostra com sementes naturalmente infectadas, os tratamentos ozônio, ácido peracético metanol, cobre e vapor de etanol não diferiram entre si. No tratamento com casugamicina a emergência de plântulas foi superior ao do tratamento com o ozônio, mas diferiu do tratamento com ácido peracético. 
Dentro dos tratamentos de sementes, os realizados com ozônio e ácido paracético afetaram negativamente a emergência de plântulas em amostras com $50 \%$ de sementes inoculadas, pois foi estatisticamente inferior quando comparado com as amostras de sementes básicas, mas não diferiu das amostras com 10 e 30\% de inoculadas e com sementes naturalmente infectadas. $\mathrm{Na}$ testemunha não houve diferença significativa entre as amostras de sementes de feijão.

O desdobramento da interação entre amostra de sementes e tratamento de sementes para índice de velocidade de emergência em campo encontra-se apresentado na Tabela 3.9. Dentro da cada amostra de sementes (sementes básicas, com 10, 30 e 50\% de sementes inoculadas e sementes naturalmente infectadas), nenhum tratamento promoveu incremento na velocidade de emergência de plântulas. Como observado para a variável emergência de plântulas, os tratamentos de sementes com ozônio e ácido peracético afetaram negativamente a velocidade de emergência, onde estes tratamentos foram estatisticamente inferiores quando comparados com a testemunha.

Dentro das amostras com sementes básicas os tratamentos com ozônio, ácido peracético, cobre, casugamicina, vapor de metanol, cloretos de benzalcônio não diferiram entre si. $\mathrm{Na}$ amostra com $10 \%$ de sementes inoculadas os tratamentos com ozônio, ácido peracético, vapor de metanol, casugamicina, vapor de etanol e cobre não diferiram. $\mathrm{Na}$ amostra com $30 \%$ de sementes inoculadas, os tratamentos com o ozônio, ácido peracético, vapor de metanol, casugamicina, vapor de etanol, cobre e cloretos de benzalcônio, também não diferiram estatisticamente. Já para a amostra com 50\% de sementes inoculadas, o tratamento com ozônio só não diferiu do tratamento com ácido peracético. O tratamento com ácido peracético não diferiu dos tratamentos com vapor de metanol, cloretos de benzalcônio, casugamicina e cobre. 
Dentro dos tratamentos de sementes houve diferença entre os tipos de amostras de sementes de feijão apenas para o tratamento com ozônio. Neste tratamento a amostra com $50 \%$ de sementes inoculadas teve menor velocidade de emergência de plântulas em relação às amostras com sementes básicas e com 10 e $30 \%$ de sementes inoculadas, mas não diferiu da amostra com sementes naturalmente infectadas.

$\mathrm{Na}$ testemunha, sementes inoculadas e naturalmente infectadas não tiveram seu vigor afetado, pois a velocidade de emergência de plântulas não diferiu das sementes básicas, indicando que, o processo de inoculação e o patógeno no interior das sementes não afetaram a qualidade fisiológica das sementes neste estudo.

Para o estabelecimento de uma lavoura, a qualidade fisiológica das sementes é ponto importante, pois está relacionado com a formação do estande e desempenho inicial das plantas. A germinação e o vigor expressam a qualidade fisiológica das sementes. A germinação é mensurada pelo teste de germinação, o qual avalia o potencial máximo de germinação de um lote, através do desenvolvimento das estruturas essenciais do embrião, até a formação de plântula, sob condições ótimas de desenvolvimento (ISTA, 1981). O termo "vigor", empregado para sementes, engloba as características que determinam o potencial para emergência rápida e uniforme, bem como o desenvolvimento de plântulas normais sob ampla variação das condições de campo (McDonald Junior, 1980). O teste de germinação tem sido amplamente utilizado na avaliação da qualidade de diferentes lotes de sementes. Entretanto esse teste é realizado em condições controladas de umidade, temperatura e aeração. Dessa maneira, nem sempre uma alta porcentagem de germinação em laboratório resulta em um excelente desempenho no campo. Isso é devido à ocorrência da diversidade de condições ambientais em que as sementes estão sujeitas no campo e que podem afetar, em maior ou menor escala, o estabelecimento inicial da cultura (Popinigis, 1985; Vieira, 1988). 
Segundo Schuch et al. (1999), a velocidade de emergência está relacionado com a velocidade dos processos metabólicos desencadeados durante a germinação e emergência. Uma maior velocidade nesses processos metabólicos faz com que as reservas sejam mais rapidamente mobilizadas das sementes e realocadas em tecidos das plântulas, resultando em uma maior velocidade de emergência das plântulas originadas de sementes de melhor qualidade fisiológica.

A partir dos dados obtidos neste experimento observa-se que os tratamentos com ozônio e ácido peracético afetaram negativamente os processos metabólicos, que são desencadeados durante a germinação e emergência em sementes de feijão.

Silva (2011) observou que grãos de trigo (Triticum aestivum L.), tratados com gás ozônio por $100,90,75$, e 36 horas nas concentrações de $0,54,1,07,1,61$ e $2,14 \mathrm{mg} \mathrm{L}^{-1}$ respectivamente, tiveram germinação inferior e condutividade elétrica superior quando comparado com grãos tratados com ar atmosférico. Resultados semelhantes foram obtidos por Rozado et al. (2008) para grãos de milho expostos ao gás ozônio na concentração de $0,11 \mathrm{mg}$ $\mathrm{L}^{-1}$ por 264 horas, onde a germinação foi inferior e a condutividade elétrica aumentou significativamente quando comparados, àqueles tratados com ar atmosférico. A variável condutividade elétrica está diretamente relacionada à integridade da membrana celular e a qualidade fisiológica das sementes, onde membranas mal estruturadas e células danificadas estão associadas ao processo de deterioração. Assim sementes com maiores valores de condutividade elétrica apresentam maiores taxas de degradação da membrana celular e, consequentemente, menor porcentual de germinação. (Vieira \& Krzyzanowski, 1999).

Hopkins et al. (2003) observaram que o tratamento de sementes de melancia (Citrullus lanatus L.) com ácido peracético, nas concentrações de 900, 1200 e $1800 \mu \mathrm{g} / \mathrm{mL}$, durante 15 e 30 minutos, não afetaram a germinação das mesmas. 
Frare (2010) observou que sementes de melão (Cucumis melo L.), sadias e inoculadas artificialmente com Acidovorax avenae subsp. citrulli, tratatadas com ácido peracético por imersão em solução ou por infiltração a vácuo, nas concentrações de 300, 1000 e $1600 \mu$ g/, não afetaram a germinação das mesmas, mas em sementes naturalmente infectadas e tratadas por infiltração a vácuo nas concentrações de 1000 e $1600 \mu \mathrm{g} / \mathrm{mL}$ tiveram germinação afetada quando comparado com sementes não tratadas.

Neste estudo, as sementes de feijão foram sensíveis ao tratamento com ácido peracético, provavelmente esta sensibilidade ocorre devido à fina espessura do tegumento do grão. 
Tabela 3.8. Efeito de diferentes tratamentos de sementes de feijão na emergência em campo. UnB, Brasília, DF, 2015.

\begin{tabular}{|c|c|c|c|c|c|c|}
\hline \multirow[b]{2}{*}{ Tratamentos } & \multicolumn{5}{|c|}{ Sementes } & \multirow[b]{2}{*}{ Média } \\
\hline & Básica & Inoculada $(10 \%) *$ & Inoculada $(30 \%) *$ & Inoculada $(50 \%)^{*}$ & Infectada $* *$ & \\
\hline Cobre & $92,08 \mathrm{~A} \mathrm{ab}$ & $87,91 \mathrm{~A} \mathrm{a}$ & $86,66 \mathrm{~A}$ ab & $85,00 \mathrm{~A} \mathrm{a}$ & $85,21 \mathrm{~A} \mathrm{abc}$ & 87,37 \\
\hline Casugamicina & $90,42 \mathrm{~A} \mathrm{ab}$ & $86,04 \mathrm{~A}$ ab & $83,75 \mathrm{~A}$ ab & $84,37 \mathrm{~A} \mathrm{a}$ & $87,71 \mathrm{~A}$ ab & 86,45 \\
\hline Ácido Peracético & $84,16 \mathrm{~A} \mathrm{bc}$ & $78,54 \mathrm{AB} b \mathrm{c}$ & $78,54 \mathrm{AB} b \mathrm{c}$ & $74,38 \mathrm{~B} \mathrm{bc}$ & $78,54 \mathrm{AB} b \mathrm{c}$ & 79,04 \\
\hline Cloretos de Benzalcônio & $90,83 \mathrm{~A} \mathrm{ab}$ & $89,37 \mathrm{~A} \mathrm{a}$ & $87,29 \mathrm{~A} \mathrm{a}$ & $83,12 \mathrm{~A} \mathrm{a}$ & $88,75 \mathrm{~A}$ a & 87,87 \\
\hline Vapor Etanol & $92,92 \mathrm{~A} \mathrm{a}$ & $88,75 \mathrm{~A}$ a & $86,46 \mathrm{~A}$ ab & $87,08 \mathrm{~A}$ a & $85,63 \mathrm{~A} a b c$ & 88,17 \\
\hline Vapor Metanol & $87,71 \mathrm{~A} \mathrm{abc}$ & $81,45 \mathrm{~A} \mathrm{abc}$ & $81,04 \mathrm{~A} \mathrm{abc}$ & $80,62 \mathrm{~A} a b$ & $83,75 \mathrm{~A} a b c$ & 82,92 \\
\hline Ozônio & $80,41 \mathrm{~A} \mathrm{c}$ & $76,04 \mathrm{AB} c$ & $74,16 \mathrm{AB} \mathrm{c}$ & $70,62 \mathrm{~B} \mathrm{c}$ & $77,08 \mathrm{AB}$ c & 75,67 \\
\hline Sem Tratamento & $95,00 \mathrm{~A} \mathrm{a}$ & $89,58 \mathrm{~A}$ a & $89,58 \mathrm{~A}$ a & $88,12 \mathrm{~A} \mathrm{a}$ & $89,58 \mathrm{~A}$ a & 90,37 \\
\hline Média & 89,19 & 84,71 & 83,44 & 81,67 & 84,66 & \\
\hline $\mathrm{CV}(\%)$ & 4,72 & & & & & \\
\hline
\end{tabular}

*Amostras com 10, 30 e 50\% de sementes inoculadas com Curtobacterium flaccumfaciens pv. flaccumfaciens por meio do método da imersão de sementes em suspensão bacteriana. **Sementes naturalmente infectadas. Médias seguidas de mesma letra, minúscula na coluna e maiúscula na linha, não diferem entre si pelo teste de Tukey a 5\% de probabilidade. DMS $S_{\text {Linha }}=7,83 ;$ DMS Coluna $=8,72$. 
Tabela 3.9. Efeito de diferentes tratamentos de sementes de feijão no índice de velocidade de emergência em campo. UnB, Brasília, DF, 2015.

\begin{tabular}{|c|c|c|c|c|c|c|}
\hline \multirow[b]{2}{*}{ Tratamentos } & \multicolumn{5}{|c|}{ Sementes } & \multirow[b]{2}{*}{ Média } \\
\hline & Básica & Inoculada $(10 \%) *$ & Inoculada $(30 \%) *$ & Inoculada $(50 \%) *$ & Infectada** & \\
\hline Cobre & $17,81 \mathrm{~A} \mathrm{ab}$ & $16,93 \mathrm{~A}$ ab & $16,70 \mathrm{~A} \mathrm{ab}$ & $16,10 \mathrm{~A}$ ab & $16,40 \mathrm{~A} \mathrm{ab}$ & 16,78 \\
\hline Casugamicina & $16,80 \mathrm{~A} a b$ & $16,28 \mathrm{~A}$ ab & $15,84 \mathrm{~A}$ ab & $15,73 \mathrm{~A}$ ab & $16,66 \mathrm{~A} a b$ & 16,26 \\
\hline Ácido Peracético & $15,68 \mathrm{~A} \mathrm{~b}$ & $14,67 \mathrm{~A} \mathrm{~b}$ & $14,60 \mathrm{~A} \mathrm{~b}$ & $14,21 \mathrm{~A} \mathrm{bc}$ & $14,74 \mathrm{~A} \mathrm{bc}$ & 14,77 \\
\hline Cloretos de Benzalcônio & $17,46 \mathrm{~A} a b$ & $17,26 \mathrm{~A} \mathrm{a}$ & $16,87 \mathrm{~A} a b$ & $15,68 \mathrm{~A}$ ab & $15,94 \mathrm{~A}$ abc & 16,64 \\
\hline Vapor Etanol & $18,31 \mathrm{~A} \mathrm{a}$ & $16,88 \mathrm{~A}$ ab & $16,44 \mathrm{~A} a b$ & $16,80 \mathrm{~A} \mathrm{a}$ & $16,56 \mathrm{~A} a b$ & 16,99 \\
\hline Vapor Metanol & $16,85 \mathrm{~A} a b$ & $15,33 \mathrm{~A} a b$ & $15,39 \mathrm{~A} \mathrm{ab}$ & $15,24 \mathrm{~A} a b$ & $15,61 \mathrm{~A} a b c$ & 15,68 \\
\hline Ozônio & $15,54 \mathrm{~A} \mathrm{~b}$ & $14,63 \mathrm{~A} \mathrm{~b}$ & $14,65 \mathrm{~A} \mathrm{~b}$ & $12,21 \mathrm{~B} \mathrm{c}$ & $13,75 \mathrm{AB} \mathrm{c}$ & 14,15 \\
\hline Sem Tratamento & $18,69 \mathrm{~A} \mathrm{a}$ & $17,45 \mathrm{~A} \mathrm{a}$ & $17,43 \mathrm{~A} \mathrm{a}$ & $17,00 \mathrm{~A} \mathrm{a}$ & $17,31 \mathrm{~A} \mathrm{a}$ & 17,57 \\
\hline Média & 17,14 & 16,18 & 15,99 & 13,37 & 15,87 & \\
\hline
\end{tabular}

*Amostras com 10, 30 e 50\% de sementes inoculadas com Curtobacterium flaccumfaciens pv. flaccumfaciens por meio do método da imersão de sementes em suspensão bacteriana. **Sementes naturalmente infectadas. Médias seguidas de mesma letra, minúscula na coluna e maiúscula na linha, não diferem entre si pelo teste de Tukey a 5\% de probabilidade. DMS $S_{\text {Linha }}=2,25 ;$ DMS $S_{\text {Coluna }}=2,51$. 


\subsection{Experimento Casa de Vegetação}

\subsubsection{Emergência e velocidade de emergência de plântulas}

Na Tabela 3.10 são apresentados os valores de emergência de plântulas em vaso e índice de velocidade de emergência, os quais estimam o efeito de diferentes tratamentos no potencial fisiológico em sementes de feijão.

Dentro das amostras de sementes, nenhum tratamento de sementes realizado promoveu incremento ou redução na emergência de plântulas, tanto em sementes básicas quanto em sementes inoculadas.

Dentro dos tratamentos de sementes, observa-se que não houve diferença na emergência de plântulas entre sementes básicas e inoculadas para todos os tratamentos, inclusive na testemunha. Os dados observados na testemunha mostraram que a inoculação por imersão em suspensão bacteriana não afetou a emergência de plântulas em condições de casa de vegetação, fato que também foi observado no experimento em campo.

Para a variável, índice de velocidade de emergência de plântulas, observa-se que dentro da amostra com sementes básicas, os tratamentos não diferem entre si. Já para sementes inoculadas, o tratamento com ozônio foi significativamente inferior quando comparado com a testemunha, mas não diferiu dos demais tratamentos. Dentro de cada tratamento de semente não houve diferença entre as amostras com sementes básicas e inoculadas, inclusive na testemunha.

Diferentemente do observado em campo, os tratamentos de sementes com ozônio e ácido peracético não afetaram a emergência e a velocidade de emergência de plântulas em condições de casa de vegetação, provavelmente isto ocorreu devido à pequena variação climática e ao suprimento hídrico adequado neste ambiente. 
Tabela 3.10. Efeito de diferentes tratamentos de sementes de feijão na emergência de plântulas em vaso (EV) e no índice de velocidade de emergência (IVE), em condições de casa de vegetação. UnB, Brasília, DF, 2015.

\begin{tabular}{cccccc}
\hline \multirow{2}{*}{ Tratamentos/Sementes } & \multicolumn{2}{c}{ EV } & & \multicolumn{2}{c}{ IVE } \\
\cline { 2 - 3 } \cline { 5 - 6 } Cobre & $93,75 \mathrm{~A} \mathrm{a}$ & $87,50 \mathrm{~A} \mathrm{a}$ & & $3,48 \mathrm{~A} \mathrm{a}$ & $3,30 \mathrm{~A} \mathrm{ab}$ \\
Casugamicina & $90,62 \mathrm{~A} \mathrm{a}$ & $86,46 \mathrm{~A} \mathrm{a}$ & & $3,36 \mathrm{~A} \mathrm{a}$ & $3,22 \mathrm{~A} \mathrm{ab}$ \\
Ácido Peracético & $86,46 \mathrm{~A} \mathrm{a}$ & $77,08 \mathrm{~A} \mathrm{a}$ & & $3,38 \mathrm{~A} \mathrm{a}$ & $2,96 \mathrm{~A} \mathrm{ab}$ \\
Cloretos de Benzalcônio & $95,83 \mathrm{~A} \mathrm{a}$ & $87,50 \mathrm{~A} \mathrm{a}$ & & $3,45 \mathrm{~A} \mathrm{a}$ & $3,30 \mathrm{~A} \mathrm{ab}$ \\
Vapor Etanol & $93,75 \mathrm{~A} \mathrm{a}$ & $87,50 \mathrm{~A} \mathrm{a}$ & & $3,69 \mathrm{~A} \mathrm{a}$ & $3,38 \mathrm{~A} \mathrm{ab}$ \\
Vapor Metanol & $86,46 \mathrm{~A} \mathrm{a}$ & $85,42 \mathrm{~A} \mathrm{a}$ & & $3,31 \mathrm{~A} \mathrm{a}$ & $3,22 \mathrm{~A} \mathrm{ab}$ \\
Ozônio & $81,25 \mathrm{~A} \mathrm{a}$ & $71,87 \mathrm{~A} \mathrm{a}$ & & $3,06 \mathrm{~A} \mathrm{a}$ & $2,49 \mathrm{~A} \mathrm{~b}$ \\
Sem Tratamento & $96,87 \mathrm{~A} \mathrm{a}$ & $91,66 \mathrm{~A} \mathrm{a}$ & $3,78 \mathrm{~A} \mathrm{a}$ & $3,55 \mathrm{~A} \mathrm{a}$ \\
\hline CV $(\%)$ & \multicolumn{3}{c}{11,20} & &
\end{tabular}

Médias seguidas de mesma letra, minúscula na coluna e maiúscula na linha, não diferem entre si (dentro de cada variável), pelo teste de Tukey a 5\% de probabilidade. DMS EV Linha $=13,95$; DMS EV Coluna $=22,02$; DMS IVE Linha $=0,63$; DMS IVE Coluna $=0,22 . *$ Amostras com $100 \%$ de sementes inoculadas com Curtobacterium flaccumfaciens pv. flaccumfaciens por meio do método da imersão de sementes em suspensão bacteriana.

\subsubsection{Desenvolvimento Vegetativo}

Para avaliação do desenvolvimento vegetativo usou-se o peso de matéria verde de parte aérea, número de trifólios e altura de planta.

O desdobramento da interação entre amostra de sementes e tratamento de sementes para peso de matéria verde de parte aérea encontra-se na Tabela 3.11. Dentro das amostras com sementes básicas e sementes inoculadas, nenhum tratamento promoveu incremento ou redução no peso de matéria verde de parte aérea. Com exceção do tratamento com vapor de metanol, todos os tratamentos de sementes, incluindo a testemunha, observou-se que o peso de matéria verde de parte aérea em plântulas oriundas de sementes inoculadas foi significativamente menor em relação às provenientes de sementes básicas. 
Tabela 3.11. Efeito de diferentes tratamentos de sementes no peso em gramas de matéria verde de parte aérea (PMV) em plântulas de feijoeiro aos 15 dias após a semeadura. UnB, Brasília, DF, 2015.

\begin{tabular}{cccc}
\hline & \multicolumn{2}{c}{ Sementes } & \multirow{2}{*}{ \% } \\
\cline { 2 - 3 } Tratamentos & Básica & Inoculada*ão & 18,23 \\
\hline Cobre & $4,77 \mathrm{~A} \mathrm{a}$ & $3,90 \mathrm{~B} \mathrm{a}$ & 23,97 \\
Casugamicina & $4,63 \mathrm{~A} \mathrm{a}$ & $3,52 \mathrm{~B} \mathrm{a}$ & 28,16 \\
Ácido Peracético & $4,58 \mathrm{~A} \mathrm{a}$ & $3,29 \mathrm{~B} \mathrm{a}$ & 18,65 \\
Cloretos de Benzalcônio & $4,77 \mathrm{~A} \mathrm{a}$ & $3,88 \mathrm{~B} \mathrm{a}$ & 23,77 \\
Vapor Etanol & $4,71 \mathrm{~A} \mathrm{a}$ & $3,59 \mathrm{~B}$ a & 9,17 \\
Vapor Metanol & $4,14 \mathrm{~A} \mathrm{a}$ & $3,76 \mathrm{~A} \mathrm{a}$ & 30,53 \\
Ozônio & $4,65 \mathrm{~A} \mathrm{a}$ & $3,23 \mathrm{~B} \mathrm{a}$ & 37,80 \\
Sem Tratamento & $4,84 \mathrm{~A}$ a & $3,01 \mathrm{~B}$ a & \\
\hline
\end{tabular}

Médias seguidas de mesma letra, minúscula na coluna e maiúscula na linha, não diferem entre si (dentro de cada variável), pelo teste de Tukey a 5\% de probabilidade. DMS PMV Linha $=0,58$; DMS PMV Coluna $=0,92$. *Amostras com $100 \%$ de sementes inoculadas com Curtobacterium flaccumfaciens pv. flaccumfaciens por meio do método da imersão de sementes em suspensão bacteriana.

O desdobramento da interação entre amostra de sementes e tratamento de sementes para número de trifólios e altura de planta encontra-se na Tabela 3.12. Dentro da amostra com sementes básicas não houve diferença entre os tratamentos tanto para número de trifólios quanto para altura de planta. Em sementes inoculadas o tratamento com cobre promoveu um aumento no número de trifólios e na estatura da planta em relação à testemunha, mas não diferiu dos demais tratamentos.

Além de bactericida o cobre é um micronutriente requerido pelas plantas em concentrações muito baixas para adequado crescimento e reprodução. De acordo com Kirkby \& Römheld (2007) o cobre está presente em diversas proteínas, as quais desempenham papel fundamental em processos tais como fotossíntese, respiração, desintoxicação de radicais 
superóxido e lignificação. Provavelmente por estas razões o tratamento das sementes de feijão com cobre promoveu um incremento no número de folhas trifolioladas e estatura em plantas oriundas de sementes inoculadas.

Dentro dos tratamentos de sementes, os realizados com casugamicina, ácido peracético e ozônio, o número de trifólios em plantas provenientes de sementes inoculadas foi significativamente menor em relação ao observado nas plantas oriundas de sementes básicas. Para a variável altura de planta, em todos os tratamentos, as plantas provenientes de sementes básicas apresentaram maior estatura em relação às de sementes de inoculadas.

Ludwig et al. (2008) avaliando desempenho de sementes de feijão de lotes com diferentes níveis de qualidade fisiológica, observaram que o número de folhas trifolioladas não foi afetado pelo nível de qualidade das sementes, no entanto as sementes de maior qualidade fisiológica produziram plantas com maior área foliar e massa seca por planta, aos 28 dias após a emergência. Resultados semelhantes foram observados por Kolchinski et al. (2006) na cultura da soja.

Segundo Schuch et al.(1999) A probabilidade de sucesso de uma lavoura aumenta com o uso de sementes de alto vigor. Sementes vigorosas apresentam maior velocidade nos processos metabólicos, propiciando emissão mais rápida e uniforme da raiz primária no processo de germinação, maiores taxas de crescimento e produzem plântulas com maior tamanho inicial.

Apesar da inoculação das sementes não ter afetado a emergência e a velocidade de emergência das plântulas, plantas oriundas de sementes inoculadas apresentaram menor desenvolvimento vegetativo. Provavelmente após a emergência das plântulas a bactéria, $C$. flaccumfaciens pv. flaccumfaciens, começou o processo infeccioso afetando processos fisiológicos da planta, bloqueado o transporte de nutrientes minerais e água através de tecidos 
condutores, resultando assim em uma menor taxa fotossintética e menor crescimento da planta.

Miranda Filho (2010) avaliando o efeito da Murcha de Curtobacterium no desenvolvimento do feijoeiro observou significativa redução no número de trifólios aos 30 dias após a inoculação, em relação às plantas não inoculadas.

Maringoni (2002) avaliando a reação de cultivares comuns de feijoeiro a Murcha de Curtobacterium observou significativa redução da matéria seca de parte aérea em plantas inoculadas, comparando com os controles não inoculados. A redução de matéria seca variou de $44,1 \%$ na cultivar "IAC Carioca Aruã" considerada resistente e de $80,7 \%$ na cultivar "Pérola", suscetível.

Chavarro et al. (1985) observaram redução de aproximadamente $37 \%$ da matéria seca de parte aérea na cultivar de feijoeiro "Porrillo Sintetico", considerada resistente à Murcha de Curtobacterium, e de $81 \%$ em Zornia glabra cultivar CIAT 7847, suscetível à doença, quando comparadas com os controles não inoculados. 
Tabela 3.12. Efeito de diferentes tratamentos de sementes no número de trifólios (NT) e na altura da planta (ALT) aos 28 dias após a semeadura. UnB, Brasília, DF, 2015.

\begin{tabular}{|c|c|c|c|c|}
\hline \multirow[b]{2}{*}{ Tratamentos/Sementes } & \multicolumn{2}{|c|}{ NT (ud) } & \multicolumn{2}{|c|}{ ALT (cm) } \\
\hline & Básica & Inoculada* & Básica & Inoculada* \\
\hline Cobre & $3,00 \mathrm{~A} \mathrm{a}$ & $2,87 \mathrm{~A} \mathrm{a}$ & $20,98 \mathrm{~A} \mathrm{a}$ & $18,77 \mathrm{~B}$ a \\
\hline Casugamicina & $2,98 \mathrm{~A} \mathrm{a}$ & $2,37 \mathrm{~B}$ ab & $19,89 \mathrm{~A} \mathrm{a}$ & $16,27 \mathrm{~B} \mathrm{ab}$ \\
\hline Ácido Peracético & $2,94 \mathrm{~A} \mathrm{a}$ & $2,50 \mathrm{~B} \mathrm{ab}$ & $19,20 \mathrm{~A} \mathrm{a}$ & $16,70 \mathrm{~B} \mathrm{ab}$ \\
\hline Cloreto de Benzalcônio & $3,06 \mathrm{~A} \mathrm{a}$ & $2,70 \mathrm{~A} a b$ & $20,30 \mathrm{~A} \mathrm{a}$ & $17,72 \mathrm{~B} a b$ \\
\hline Vapor Etanol & $3,02 \mathrm{~A} \mathrm{a}$ & $2,75 \mathrm{~A} a b$ & $20,87 \mathrm{~A} \mathrm{a}$ & $17,91 \mathrm{~B} \mathrm{ab}$ \\
\hline Vapor Metanol & $3,02 \mathrm{~A} \mathrm{a}$ & $2,71 \mathrm{~A} \mathrm{ab}$ & $20,84 \mathrm{~A} \mathrm{a}$ & $17,94 \mathrm{~B} \mathrm{ab}$ \\
\hline Ozônio & $3,10 \mathrm{~A} \mathrm{a}$ & $2,56 \mathrm{~B}$ ab & $19,52 \mathrm{~A} \mathrm{a}$ & $17,16 \mathrm{~B}$ ab \\
\hline Sem Tratamento & $3,00 \mathrm{~A} \mathrm{a}$ & $2,27 \mathrm{~B} \mathrm{~b}$ & $20,73 \mathrm{~A}$ a & $14,99 \mathrm{~B} \mathrm{~b}$ \\
\hline $\mathrm{CV}(\%)$ & & & & \\
\hline
\end{tabular}

Médias seguidas de mesma letra, minúscula na coluna e maiúscula na linha, não diferem entre si (dentro de cada variável), pelo teste de Tukey a 5\% de probabilidade. DMS NT Linha $=0,36$; DMS NT Coluna $=0,58$; DMS ALT Linha $=1,96 ;$ DMS ALT Coluna $=3,09$. *Amostras com $100 \%$ de sementes inoculadas com Curtobacterium flaccumfaciens pv. flaccumfaciens por meio do método da imersão de sementes em suspensão bacteriana.

\subsubsection{Incidência e severidade da Murcha de Curtobacterium}

Os dados de incidência de Murcha de curtobacterium aos 30, 45 e 60 dias após a semeadura encontram-se na Tabela 3.13.

Nas três épocas de avaliação não foram detectadas diferenças significativas entre os tratamentos de sementes, para os dados de incidência de plantas com Murcha de Curtobacterium, onde nenhum tratamento realizado em sementes inoculadas diferiu da testemunha. A incidência de plantas com sintomas da doença foi superior à incidência de sementes contaminadas com $C f f$ após os tratamentos de sementes realizados neste estudo. Provavelmente muitas dessas infecções se desenvolveram a partir de dispersão secundária de inóculo. A partir desta observação pode-se inferir que em um lote de sementes com baixa incidência de $C f f$ é capaz de gerar uma epidemia da doença em uma lavoura comercial de feijão. 
Tabela 3.13. Efeito de diferentes tratamentos de sementes na incidência (\%) de plantas de feijoeiro com sintomas de Murcha de Curtobacterium, causada por Curtobacterium flaccumfaciens pv. flaccumfaciens, aos 30, 45 e 60 dias após a semeadura (DAS). UnB, Brasília, DF, 2015.

\begin{tabular}{cccc}
\hline Tratamentos & Incidência (30 DAS) & Incidência (45 DAS) & Incidência (60 DAS) \\
\hline Cobre & $93,75^{\mathrm{ns}}$ & $100^{\mathrm{ns}}$ & $100^{\mathrm{ns}}$ \\
Casugamicina & 93,75 & 100 & 100 \\
Ácido Peracético & 97,92 & 100 & 100 \\
Cloretos de Benzalcônio & 83,33 & 87,50 & 87,50 \\
Vapor Etanol & 91,67 & 100 & 100 \\
Vapor Metanol & 66,67 & 68,75 & 68,75 \\
Ozônio & 83,33 & 100 & 100 \\
Sem Tratamento & 100 & 100 & 100 \\
\hline CV $\%)$ & 28,99 & 20,53 & 20,53 \\
\hline
\end{tabular}

ns= não significativo a $5 \%$ pelo teste $\mathrm{F}$.

Os dados de severidade, avaliados aos 30, 45 e 60 dias após a semeadura, e área abaixo da curva de progresso da Murcha de Curtobacterium (AACPMC), encontram-se na Tabela 3.14.

Através da análise de variância, das notas de severidade, nas três avaliações, e da AACPMC, não foram constatadas diferenças significativas entre os tratamentos de sementes, demonstrando que nenhum tratamento realizado em sementes inoculadas foi eficiente na redução da severidade da Murcha de Curtobacterium. 
Tabela 3.14. Efeito de diferentes tratamentos de sementes na severidade da doença, aos 30 , 45 e 60 dias após a semeadura, e área abaixo da curva de progresso da Murcha de Curtobacterium, causada por Curtobacterium flaccumfaciens pv. flaccumfaciens. UnB, Brasília, DF, 2015.

\begin{tabular}{ccccc}
\hline Tratamentos & $\begin{array}{c}\text { Severidade } \\
(\mathbf{3 0} \mathbf{D A S})\end{array}$ & $\begin{array}{c}\text { Severidade } \\
(\mathbf{4 5} \mathbf{D A S})\end{array}$ & $\begin{array}{c}\text { Severidade } \\
(\mathbf{6 0} \mathbf{D A S})\end{array}$ & AACPMC \\
\hline Cobre & $3,08^{\mathrm{ns}}$ & $5,58^{\mathrm{ns}}$ & $6,75^{\mathrm{ns}}$ & $157,50^{\mathrm{ns}}$ \\
Casugamicina & 3,43 & 5,33 & 6,58 & 155,16 \\
Ácido Peracético & 3,68 & 5,79 & 6,83 & 165,78 \\
$\begin{array}{c}\text { Cloretos de } \\
\text { Benzalcônio }\end{array}$ & 3,37 & 5,17 & 6,16 & 149,06 \\
Vapor Etanol & 3,58, & 5,91 & 7,33 & 170,62 \\
Vapor Metanol & 2,49 & 4,14 & 4,44 & 114,22 \\
Ozônio & 4,12 & 6,00 & 7,37 & 176,25 \\
Sem Tratamento & 4,21 & 6,16 & 8,12 & 185,00 \\
\hline CV(\%) & 42,21 & 30,36 & 24,16 & 27,54 \\
\hline
\end{tabular}

ns= não significativo a $5 \%$ pelo teste $\mathrm{F}$.

\subsubsection{Produção}

Para avaliar a produção em cada parcela, usaram-se os parâmetros: número de vagens $(\mathrm{NV})$, número de grãos (NG), massa de grãos (PG), número de grãos por grama (NGG), porcentagem de grãos abortados (PGA) e número de grãos abortados por vagem (NGAV).

Com relação ao número de vagens e ao número de grãos por parcela a interação amostra de sementes $\mathrm{x}$ tratamento de sementes foi significativa. $\mathrm{O}$ desdobramento encontra-se na Tabela 3.15.

Analisando os resultados dos tratamentos de sementes dentro de amostra de sementes observou-se que em sementes básicas os tratamentos de sementes não influenciaram na produção de vagens, já em sementes inoculadas os tratamentos com cloretos de benzalcônio e vapor de metanol promoveram um aumento no número de vagens, em relação à testemunha. No que se refere ao efeito das amostras de sementes dentro de tratamento de sementes, 
verificou-se que nos tratamentos com cloretos de benzalcônio e vapor de metanol, o número de vagens em plantas provenientes de sementes básicas e inoculadas não diferem entre si, enquanto para os demais tratamentos as plantas oriundas de sementes inoculadas produziram quantidade significativamente menor de vagens.

Quanto ao desdobramento tratamentos de sementes dentro de cada amostra de sementes referente ao número de grãos, verificou-se que em plantas oriundas de sementes básicas os tratamentos de sementes não promoveram incremento ou redução no número de grãos nas plantas provenientes de sementes básicas, porém o tratamento de sementes com vapor de metanol promoveu um aumento no número de grãos em plantas provenientes de sementes inoculadas, em relação à testemunha, mas não diferiu dos demais tratamentos de sementes.

Analisando o desdobramento amostras de sementes dentro de tratamento de sementes, verifica-se que apenas no tratamento com vapor de metanol não houve redução significativa no número de grãos em plantas oriundas de sementes inoculadas em relação a sementes de básicas. Nos demais tratamentos, o número de grãos produzidos em plantas provenientes de sementes inoculadas foi estatisticamente menor. 
Tabela 3.15. Efeito de diferentes tratamentos de sementes de feijão no número de vagens (NV) e no número de grãos por parcela (NG). UnB, Brasília, DF, 2015.

\begin{tabular}{|c|c|c|c|c|}
\hline \multirow[b]{2}{*}{ Tratamentos/Sementes } & \multicolumn{2}{|c|}{ NV (ud) } & \multicolumn{2}{|c|}{ NG (ud) } \\
\hline & Básica & Inoculada* & Básica & Inoculada* \\
\hline Cobre & $49,75 \mathrm{~A} \mathrm{a}$ & $37,75 \mathrm{~B}$ abc & $212,50 \mathrm{~A} \mathrm{a}$ & $125,75 \mathrm{~B} \mathrm{ab}$ \\
\hline Casugamicina & $43,75 \mathrm{~A} \mathrm{a}$ & $30,25 \mathrm{~B}$ bc & $184,75 \mathrm{~A} \mathrm{a}$ & $109,50 \mathrm{~B} \mathrm{ab}$ \\
\hline Ácido Peracético & $46,00 \mathrm{~A} \mathrm{a}$ & $31,00 \mathrm{~B} \mathrm{bc}$ & $193,25 \mathrm{~A}$ a & $107,00 \mathrm{~B} \mathrm{ab}$ \\
\hline Cloretos de Benzalcônio & $48,00 \mathrm{~A} \mathrm{a}$ & $40,75 \mathrm{~A} a b$ & $184,50 \mathrm{~A} \mathrm{a}$ & $136,50 \mathrm{~B} \mathrm{ab}$ \\
\hline Vapor Etanol & $49,50 \mathrm{~A} \mathrm{a}$ & $34,00 \mathrm{~B}$ abc & $190,75 \mathrm{~A} \mathrm{a}$ & $113,50 \mathrm{~B}$ ab \\
\hline Vapor Metanol & $45,25 \mathrm{~A} \mathrm{a}$ & $42,50 \mathrm{~A} \mathrm{a}$ & $179,50 \mathrm{~A} a$ & $150,50 \mathrm{~A} \mathrm{a}$ \\
\hline Ozônio & $50,25 \mathrm{~A} \mathrm{a}$ & $33,25 \mathrm{~B}$ abc & $213,25 \mathrm{~A}$ a & $105,50 \mathrm{~B} \mathrm{ab}$ \\
\hline Sem Tratamento & $53,00 \mathrm{~A} \mathrm{a}$ & $28,00 \mathrm{~B} \mathrm{c}$ & $228,50 \mathrm{~A} \mathrm{a}$ & $93,50 \mathrm{~B} \mathrm{~b}$ \\
\hline $\mathrm{CV}(\%)$ & & & & \\
\hline
\end{tabular}

Médias seguidas de mesma letra, minúscula na coluna e maiúscula na linha, não diferem entre si (dentro de cada variável), pelo teste de Tukey a 5\% de probabilidade. DMS NV Linha $_{1}=7,28 ;$ DMS NV coluna $=11,48 ;$ DMS NG Linha $=34,22 ;$ DMS NG Coluna $=54,01$. *Amostras com $100 \%$ de sementes inoculadas com Curtobacterium flaccumfaciens pv. flaccumfaciens por meio do método da imersão de sementes em suspensão bacteriana.

Os dados obtidos para número de grãos abortados por vagem mostraram efeito significativo para a interação amostra de sementes $\mathrm{x}$ tratamento de sementes. $\mathrm{O}$ desdobramento da interação encontra-se na Tabela 3.16. Analisando os resultados dos tratamentos de sementes dentro de amostra de sementes verifica-se que em plantas provenientes de sementes inoculadas, os tratamentos com cloretos de benzalcônio e vapor de metanol reduziram o número de grãos abortados por vagem, quando comparados com os tratamentos realizados com casugamicina e ácido peracético, além da testemunha. No que se refere às amostras de sementes dentro de tratamento de sementes, observa-se que em plantas provenientes de sementes inoculadas o número de grãos abortados por vagem é significativamente maior, em relação a plantas oriundas de sementes básicas, exceto para os tratamentos com cloretos de benzalcônio e vapor de metanol, onde não houve diferença entre o uso de sementes inoculadas e básicas. 
$O$ efeito da interação significativa amostra de sementes $x$ tratamento de sementes referente porcentagem de grãos abortados, encontra-se na Tabela 3.16, onde os resultados dos tratamentos de sementes dentro de cada amostra de semente mostraram que em sementes inoculadas os tratamentos com cloretos de benzalcônio e vapor de metanol reduziram a porcentagem de grãos abortados em relação às plantas oriundas de sementes tratatadas com casugamicina, ozônio e a testemunha. Analisando o desdobramento das amostras de semente dentro de cada tratamento de sementes, observou-se que para os tratamentos com cloretos de benzalcônio e vapor de metanol não houve diferença na porcentagem de grãos abortados entre plantas provenientes de sementes inoculadas e básicas, fato que não foi observado para os demais tratamentos, onde a porcentagem de grãos abortados foi significativamente maior em plantas oriundas de sementes inoculadas.

Tabela 3.16. Efeito de diferentes tratamentos de sementes de feijão nos parâmetros número grãos abortados por vagem (NAV) e porcentagem de grãos abortados (PGA). UnB, Brasília, DF, 2015.

\begin{tabular}{cccccc}
\hline \multirow{2}{*}{ Tratamentos/Sementes } & \multicolumn{2}{c}{ BÁsica } & Inoculada* & & \multicolumn{2}{c}{ Básica } & Inoculada* \\
\cline { 2 - 3 } \cline { 5 - 6 } Cobre & $0,68 \mathrm{~B} \mathrm{a}$ & $1,21 \mathrm{~A} \mathrm{ab}$ & & $13,78 \mathrm{~A} \mathrm{a}$ & $26,59 \mathrm{~B} \mathrm{ab}$ \\
Casugamicina & $0,92 \mathrm{~B} \mathrm{a}$ & $1,93 \mathrm{~A} \mathrm{a}$ & & $16,35 \mathrm{~A} \mathrm{a}$ & $34,15 \mathrm{~B} \mathrm{a}$ \\
Ácido Peracético & $0,67 \mathrm{~B} \mathrm{a}$ & $1,81 \mathrm{~A} \mathrm{a}$ & & $13,67 \mathrm{~A} \mathrm{a}$ & $33,03 \mathrm{~B} \mathrm{ab}$ \\
Cloretos de Benzalcônio & $0,88 \mathrm{~A} \mathrm{a}$ & $0,98 \mathrm{~A} \mathrm{~b}$ & & $20,31 \mathrm{~A} \mathrm{a}$ & $20,89 \mathrm{~A} \mathrm{~b}$ \\
Vapor Etanol & $0,67 \mathrm{~B} \mathrm{a}$ & $1,42 \mathrm{~A} \mathrm{ab}$ & & $14,68 \mathrm{~A} \mathrm{a}$ & $29,59 \mathrm{~B} \mathrm{ab}$ \\
Vapor Metanol & $0,82 \mathrm{~A} \mathrm{a}$ & $0,93 \mathrm{~A} \mathrm{~b}$ & & $17,06 \mathrm{~A} \mathrm{a}$ & $20,71 \mathrm{~A} \mathrm{~b}$ \\
Ozônio & $0,77 \mathrm{~B} \mathrm{a}$ & $1,65 \mathrm{~A} \mathrm{ab}$ & & $15,20 \mathrm{~A} \mathrm{a}$ & $34,97 \mathrm{~B} \mathrm{a}$ \\
Sem Tratamento & $0,69 \mathrm{~B} \mathrm{a}$ & $1,88 \mathrm{~A} \mathrm{a}$ & $13,76 \mathrm{~A} \mathrm{a}$ & $36,22 \mathrm{~B} \mathrm{a}$ \\
\hline CV $(\%)$ & \multicolumn{3}{c}{24,53} \\
\end{tabular}

Médias seguidas de mesma letra, minúscula na coluna e maiúscula na linha, não diferem entre si (dentro de cada variável), pelo teste de Tukey a 5\% de probabilidade. DMS NAV ${ }_{\text {Linha }}=0,52 ;$ DMS NAV Coluna $=0,82 ;$ DMS $\operatorname{PGA}_{\text {Linha }}=7,88$; DMS PGA Coluna $=12,44{ }^{*}$ Amostras com $100 \%$ de sementes inoculadas com Curtobacterium flaccumfaciens pv. flaccumfaciens por meio do método da imersão de sementes em suspensão bacteriana. 
Os resultados obtidos quanto à produção por parcela mostram um efeito significativo da interação amostra de sementes $\mathrm{x}$ tratamento de sementes. $\mathrm{O}$ desdobramento da interação para a variável produção por parcela encontra-se na Tabela 3.17. Os dados dos tratamentos de sementes dentro de amostra de sementes mostraram que nenhum dos tratamentos realizados em sementes básicas ou inoculadas promoveu incremento ou redução da produção. Os resultados de amostras de sementes dentro de tratamento de sementes mostraram que em todos os tratamentos, plantas oriundas de sementes básicas tiveram produção superior, em relação às provenientes de sementes inoculadas.

Tabela 3.17. Efeito de diferentes tratamentos de sementes de feijão na produção (g) de grãos por parcela (PG). UnB, Brasília, DF, 2015.

\begin{tabular}{cccc}
\hline & \multicolumn{2}{c}{ Sementes } \\
\cline { 2 - 3 } Tratamentos & Básica & Inoculada* & \% Redução \\
\hline Cobre & $66,83 \mathrm{~A} \mathrm{a}$ & $35,30 \mathrm{~B} \mathrm{a}$ & 47,18 \\
Casugamicina & $58,39 \mathrm{~A} \mathrm{a}$ & $30,85 \mathrm{~B} \mathrm{a}$ & 47,16 \\
Ácido Peracético & $59,58 \mathrm{~A} \mathrm{a}$ & $27,72 \mathrm{~B} \mathrm{a}$ & 53,47 \\
Cloretos de Benzalcônio & $59,05 \mathrm{~A} \mathrm{a}$ & $37,77 \mathrm{~B} \mathrm{a}$ & 36,03 \\
Vapor Etanol & $61,48 \mathrm{~A} \mathrm{a}$ & $32,74 \mathrm{~B} \mathrm{a}$ & 46,75 \\
Vapor Metanol & $62,23 \mathrm{~A} \mathrm{a}$ & $42,06 \mathrm{~B}$ a & 32,41 \\
Ozônio & $71,04 \mathrm{~A} \mathrm{a}$ & $30,16 \mathrm{~B}$ a & 57,54 \\
Sem Tratamento & $75,56 \mathrm{~A} \mathrm{a}$ & $24,81 \mathrm{~B} \mathrm{a}$ & 67,16 \\
\hline CV $(\%)$ & 16,68 & &
\end{tabular}

Médias seguidas de mesma letra, minúscula na coluna e maiúscula na linha, não diferem entre si pelo teste de Tukey a $5 \%$ de probabilidade. DMS ${ }_{\text {Linha }}=11,51$; DMS Coluna $=18,16{ }^{*}$ Amostras com $100 \%$ de sementes inoculadas com Curtobacterium flaccumfaciens pv. flaccumfaciens por meio do método da imersão de sementes em suspensão bacteriana.

O desdobramento da interação para o parâmetro produtivo, número de grãos por vagem, encontra-se na Tabela 3.18. Analisando o efeito dos tratamentos de sementes dentro de amostra de sementes, observou-se que nenhum tratamento promoveu incremento ou 
redução no número de grãos por vagem, tanto em plantas oriundas de sementes básicas quanto de sementes inoculadas. Analisando o desdobramento amostras de sementes dentro de tratamento de sementes, verifica-se que em todos os tratamentos, exceto cloretos benzalcônio e vapor de metanol, o número de grãos por vagem foi menor em plantas oriundas de sementes inoculadas.

O desdobramento da interação referente ao número de grãos por grama encontra-se na Tabela 3.18. Os resultados dos tratamentos de sementes dentro de cada amostra de sementes mostraram que os tratamentos de sementes não tiveram influência nesta variável, tanto em amostras com sementes básicas quanto inoculadas. No entanto, os resultados de amostras de sementes dentro de cada tratamento de sementes evidenciaram que em todos os tratamentos, o parâmetro número de grãos por gramas foi maior em plantas oriundas de sementes inoculadas, indicando que plantas provenientes de sementes básicas produzem grãos mais pesados. 
Tabela 3.18. Efeito de diferentes tratamentos de sementes de feijão nos parâmetros produtivos, número de grãos por vagem $(\mathrm{NGV})$ e número de grãos por grama (NGG). UnB, Brasília, DF, 2015.

\begin{tabular}{cccccc}
\hline & \multicolumn{2}{c}{ NGV } & & \multicolumn{2}{c}{ NGG } \\
\cline { 2 - 3 } \cline { 5 - 6 } Tratamentos/Sementes & Básica & Inoculada* & & Bnoculada* \\
\hline Cobre & $4,28 \mathrm{~A} \mathrm{a}$ & $3,34 \mathrm{~B} \mathrm{a}$ & & $3,18 \mathrm{~B} \mathrm{a}$ & $3,57 \mathrm{~A} \mathrm{a}$ \\
Casugamicina & $4,22 \mathrm{~A} \mathrm{a}$ & $3,64 \mathrm{~B} \mathrm{a}$ & & $3,17 \mathrm{~B} \mathrm{a}$ & $3,54 \mathrm{~A} \mathrm{a}$ \\
Ácido Peracético & $4,20 \mathrm{~A} \mathrm{a}$ & $3,46 \mathrm{~B} \mathrm{a}$ & & $3,25 \mathrm{~B} \mathrm{a}$ & $3,85 \mathrm{~A} \mathrm{a}$ \\
Cloretos de Benzalcônio & $3,85 \mathrm{~A} \mathrm{a}$ & $3,34 \mathrm{~A} \mathrm{a}$ & & $3,13 \mathrm{~B} \mathrm{a}$ & $3,60 \mathrm{~A} \mathrm{a}$ \\
Vapor Etanol & $3,86 \mathrm{~A} \mathrm{a}$ & $3,34 \mathrm{~B} \mathrm{a}$ & & $3,10 \mathrm{~B} \mathrm{a}$ & $3,48 \mathrm{~A} \mathrm{a}$ \\
Vapor Metanol & $3,95 \mathrm{~A} \mathrm{a}$ & $3,54 \mathrm{~A} \mathrm{a}$ & & $2,86 \mathrm{~B} \mathrm{a}$ & $3,58 \mathrm{~A} \mathrm{a}$ \\
Ozônio & $4,20 \mathrm{~A} \mathrm{a}$ & $3,19 \mathrm{~B} \mathrm{a}$ & & $3,07 \mathrm{~B} \mathrm{a}$ & $3,46 \mathrm{~A} \mathrm{a}$ \\
Sem Tratamento & $4,31 \mathrm{~A} \mathrm{a}$ & $3,29 \mathrm{~B} \mathrm{a}$ & $3,04 \mathrm{~B} \mathrm{a}$ & $3,78 \mathrm{~A} \mathrm{a}$ \\
\hline CV $(\%)$ & \multicolumn{3}{c}{7,55} & &
\end{tabular}

Médias seguidas de mesma letra, minúscula na coluna e maiúscula na linha, não diferem entre si (dentro de cada variável), pelo teste de Tukey a 5\% de probabilidade. DMS NGV Linha $=0,51 ;$ DMS NGV Coluna $=0,81 ;$ DMS $\mathrm{NGG}_{\text {Linha }}=0,36$; DMS NGG Coluna $=0,57 . *$ Amostras com $100 \%$ de sementes inoculadas com Curtobacterium flaccumfaciens pv. flaccumfaciens por meio do método da imersão de sementes em suspensão bacteriana.

Segundo Didonet (2003) a cultura do feijoeiro deve ser manejada de maneira a permitir o acúmulo máximo de biomassa, e que uma proporção máxima dessa biomassa seja "desviada" para os grãos. Por exemplo, se o acúmulo de biomassa total é limitado por algum fator (água, luz e nutrientes), seguramente o rendimento de grãos será baixo, pois a biomassa disponível para ser "desviada" para os grãos é limitada pela disponibilidade de biomassa total. De maneira geral, a planta regula o número ideal de vagens e de grãos que ela pode ter, basicamente pela disponibilidade de nutrientes e, principalmente, pela disponibilidade de carboidratos. De acordo com Maringoni (2002) plantas de feijoeiro colonizadas por Cff apresentam desenvolvimento vegetativo reduzido ocasionado pelas alterações fisiológicas provocadas pela Murcha de Curtobacterium, fato que também foi observado neste estudo. 
Em todos os tratamentos de sementes, incluindo a testemunha, a produção em plantas oriundas de sementes inoculadas apresentou valores significativamente inferiores quando comparadas com o rendimento produtivo de plantas provenientes de sementes básicas. Embora o tratamento com vapor de metanol tenha proporcionado um incremento no número de vagens e grãos, além de uma redução no abortamento de grãos em plantas oriundas de sementes inoculadas, este tratamento não proporcionou um aumento significativo na massa total de grãos.

Provavelmente esta menor produção, observada em plantas provenientes de sementes inoculadas e com sintomas da Murcha de Curtobacterium, ocorreu devido à limitação de água e nutrientes, provocada pela interrupção no fluxo de seiva bruta no xilema, ocasionando menor taxa fotossintética e consequentemente menor acúmulo de fotoassimilados pela planta.

Estefani (2004) avaliou o efeito dos tratamentos térmico e químico em grãos de feijão, cultivar Pérola, oriundos de campo com alta incidência de Murcha de Curtobacterium, sobre a germinação, produtividade e peso de 100 sementes, em condições de campo. Os tratamentos testados foram: semente básica (SB) como testemunha; grãos colhidos em campo, sem termoterapia nem tratamento químico (GR); grãos colhidos em campo contaminado e submetidos a 2 horas de imersão e 3 horas sob temperatura de $60^{\circ} \mathrm{C}$ (GRT) e grãos colhidos em campo contaminado e submetido a 2 horas de imersão em solução de Agrimaicin ${ }^{\circledR} 10 \mathrm{~g} / \mathrm{L}$ (GRA). De acordo com os dados obtidos pela autora, o tratamento que proporcionou maior percentual de germinação foi o SB com $92,92 \%$, o qual diferiu estatisticamente do tratamento GRA $(84,06 \%)$, os demais tratamentos não diferiram entre si. Com relação à produtividade, foi observado que não houve diferenças significativas entre os tratamentos, embora o tratamento GRT tenha apresentado maior produtividade que os demais sendo este com 2180,0 kg/ha, SB (2140,0 kg/ha), GRA (2130,0 kg/ha) e GR (1933,2 kg/ha). Quanto à massa de 100 sementes, foi observado que os tratamentos SB $(26,08 \mathrm{~g})$, GRT $(25,85 \mathrm{~g})$, GRA $(25,07 \mathrm{~g})$ 
foram estatisticamente superiores ao GRA $(23,7 \mathrm{~g})$. Em condições de casa de vegetação utilizando os mesmos tratamentos, a autora observou que o tratamento GR apresentou menor percentual de germinação em relação ao SB, mas não diferiu dos demais tratamentos. Já para as demais variáveis, número de vagens, produção e massa 100 sementes, os tratamentos não diferiram entre si.

Miranda Filho (2010), avaliando a eficiência do tratamento químico de grãos naturalmente infectados por $C f f$, com diferentes produtos fitossanitários, no controle da Murcha de Curtobacterium, observou que os tratamentos dos grãos por imersão em solução de Agrimaicin $500^{\circledR}$ (oxitetraciclina $30 \mathrm{~g} / \mathrm{Kg}+$ sulfato de cobre $500 \mathrm{~g} / \mathrm{Kg}$ ), Agri-Micina ${ }^{\circledR}$ (oxitetraciclina $15 \mathrm{~g} / \mathrm{Kg}+$ sulfato de estreptomicina $150 \mathrm{~g} / \mathrm{Kg}$ ), Mycoshield ${ }^{\circledR}$ (oxitetraciclina $^{(2)}$ 200g/Kg), e Fegatex ${ }^{\circledR}$ (cloretos de benzalcônio $100 \mathrm{~g} / \mathrm{L}$ ) nas dosagens, respectivamente 4,0 g, 3,0 g, 2,0 g e $3 \mathrm{~mL}$ do produto comercial em $\mathrm{L}^{-1}$ de água, durante 20 minutos, não afetaram a emergência de plântulas em campo. Em relação à produtividade e massa de 100 grãos, não foi verificado pelo autor diferença significativa entre os tratamentos. Os tratamentos de sementes também não diferiram da testemunha (sem tratamento), indicando que os produtos utilizados não foram eficientes na erradicação da $C f f$.

Resultados observados no presente trabalho e também por Estefani (2004) e Miranda Filho (2010) evidenciam a importância do uso de sementes de elevada qualidade sanitária e fisiológica para obtenção de resultados satisfatórios na cultura do feijoeiro, pois nenhum tratamento de sementes proposto até o momento superou ou igualou o uso de sementes livres de Cff para o controle da Murcha de Curtobacterium.

Os tratamentos com vapor de metanol e cloretos de benzalcônio mostraram potencial para erradicação de $C f f$ em sementes de feijão, embora não tenham proporcionado redução na incidência e severidade da doença, e incremento na produção. No entanto, serão necessários 
mais estudos para melhorar a eficiência destes tratamentos como: formas de aplicação, tempos de exposição e combinação destes fatores.

\subsection{Taxa de transmissão planta - semente de $C f f$}

Os resultados obtidos a partir do isolamento de Cff em sementes colhidas em plantas de feijoeiro, cultivar Pérola, severamente atacadas pela Murcha de Curtobacterium encontram-se na Tabela 3.19. Verifica-se que a taxa de transmissão de $C f f$ das plantas paras as sementes foi na ordem de $23,75 \%$.

Tabela 3.19. Transmissão planta - semente de Curtobacterium flaccumfaciens pv. flaccumfaciens em plantas de feijoeiro, cultivar Pérola, oriundas de sementes inoculadas. UnB, Brasília, DF, 2015.

\begin{tabular}{ccc}
\hline Subamostra & $\begin{array}{c}\mathbf{N}^{\mathbf{0}} \text { de sementes analisadas } / \mathbf{n}^{\mathbf{0}} \text { de } \\
\text { sementes infectas com } \boldsymbol{C f f}\end{array}$ & \% de transmissão de $\boldsymbol{C f f}$ \\
\hline 1 & $20 / 3$ & 15 \\
2 & $20 / 5$ & 25 \\
3 & $20 / 5$ & 25 \\
4 & $20 / 6$ & 30 \\
\hline Média & -- & 23,75 \\
\hline
\end{tabular}

O valor obtido para a transmissão de $C f f$ das plantas para sementes está próximo do observado por Estefani (2004), onde a autora verificou uma taxa de infecção na ordem de $19 \%$ em sementes de feijão, cultivar Pérola, colhidas em campo com alta incidência de Murcha de Curtobacterium.

Chavarro et al. (1985) constatou que sob condições de inoculação artificial, a transmissão de $C f f$ na ordem de $52,5 \%$ em sementes de feijão e de $88,8 \%$ em sementes de Zornia glabra. 
Camara et al. (2009) avaliando a transmissão de Cff via sementes em plantas de feijoeiro inoculadas via punção no caule, em três ensaios, em seis cultivares, observaram que as cultivares resistentes à Murcha de Curtobacterium, IAC Carioca Akytã, IAC Carioca Pyatã e IAC Carioca Tybatã não apresentaram transmissão da bactéria, enquanto a cultivar IAC Carioca Aruã, apresentou a transmissão na ordem de 5,5 a 14,8\% e as cultivares suscetíveis, IAC Carioca e Pérola apresentaram uma alta porcentagem de transmissão; a cultivar IAC Carioca, entre 10,4 a 70\%, e a Pérola, entre 32,61 a 74,2 \%.

A partir dos dados obtidos e dos relatos na literatura, verifica-se que a taxa de transmissão de Cff via semente, varia de acordo com o método de inoculação, espécie hospedeira, cultivar e nível de resistência à Murcha de Curtobacterium. 


\section{CONCLUSÕES}

- Os produtos cúpricos, sulfato de cobre e óxido cuproso, mostraram melhor eficiência na inibição do crescimento de Cff "in vitro".

- Os princípios ativos cloretos de benzalcônio, casugamicina e ácido peracético, nas concentrações de 20, 100 e $200 \mu \mathrm{g} / \mathrm{mL}$ respectivamente, inibiram o crescimento de Cff "in vitro".

- O método de inoculação usado nesse trabalho é eficiente em associar Cff à semente de feijão.

- Os tratamentos de sementes com cloretos de benzalcônio e vapor de metanol foram os mais eficientes na redução da população de $C f f$ em sementes de feijão.

- Os tratamentos com ácido peracético e ozônio afetaram o vigor das sementes em condições de campo.

- Nenhum tratamento proposto neste estudo afetou o vigor das sementes em condições de casa de vegetação.

- O método de inoculação usado nesse estudo não afetou o vigor das sementes em condições de campo e casa de vegetação.

- Plantas oriundas de sementes inoculadas com Cff têm seu desenvolvimento vegetativo reduzido.

- Nenhum dos tratamentos de sementes testados foi eficiente em reduzir a incidência e a severidade da Murcha de Curtobacterium.

- Nenhum dos tratamentos de sementes realizado promoveu incremento na produção de grãos.

- A transmissão de Cff das plantas para as sementes foi de $23,75 \%$, nesse estudo. 


\section{REFERÊNCIAS BIBLIOGRÁFICAS}

ABRASEM - Associação Brasileira de Sementes e Mudas. 2013. Estatísticas. http://www.abrasem.com.br/category/estatisticas/\#. Consultado em: 01/08/2014.

ABREU, A.F.B. 2005. Cultivo do Feijão da Primeira e Segunda Safras na Região Sul de Minas Gerais: Produção de Sementes. Embrapa Arroz e Feijão: Sistema de Produção. http://sistemasdeproducao.cnptia.embrapa.br/FontesHTML/Feijao/FeijaoPrimSegSafraSulMG /psementes.htm. Consultado em 13/06/2014.

ABREU, F.M.; LOURENÇO, S.A.; BASSETTO, E.; GONÇALVES, F.P.; MARTINS, M.C. \& AMORIM, L. 2008. Efeito de sanificantes no controle pós-colheita da podridão parda (Monilinia fructicola) e da podridão mole (Rhizopus stolonifer) em pêssegos. Summa Phytopathologica 34(1): 86-88.

ADASKAVEG, J.E.; FOSTER, H. \& SOMMER, N.F. 2002. Principles of postharvest pathology and management of decays of edible horticultural crops. In: Kader, A.A. (ed.). Postharvest Technology of Horticultural Crops. p.163-196.

AGROFIT: Sistemas de agrotóxicos fitossanitários. http://extranet.agricultura.gov.br/agrofit_cons/principal_agrofit_cons. Consultado em: $17 / 04 / 2014$.

AGUIAR, L.A.; KIMURA, O.; CASTILHO, A.M.; CASTILHO, K.S.C.; RIBEIRO, R.L.D.; AKIBA, F. \& CARMO, M.G.F. 2000. Resistência ao cobre em isolados nacionais de Xanthomonas campestris pv. vesicatoria de pimentão e tomateiro. Agronomia 34:78-82.

AIDAR, H. 2003. Cultivo Feijoeiro Comum: Características da Cultura. http://sistemasdeproducao.cnptia.embrapa.br/FontesHTML/Feijao/CultivodoFeijoeiro/index.h tm. Consultado em 31/07/2014. 
ALENCAR, E.R. 2009. Processo de ozonização de amendoim (Arachis hypogaea L.): cinética de decomposição, efeito fungicida e detoxificante de aflatoxinas e aspectos qualitativos. Tese de Doutorado. Universidade Federal de Viçosa. Viçosa, Brasil.

ANDRADE, M.J.B.; CARVALHO, A.J. \& VIEIRA, N.M. 2008. Exigências Edafoclimáticas. In: VIEIRA, C.; PAULA JÚNIOR, J. \& BORÉM. A. (eds.). Feijão. $2^{\mathrm{a}}$ ed. UFV. Viçosa. p.6786.

ARAÚJO, G.A. de A. \& FERREIRA, A.C. de B. Manejo do Solo e Plantio. 2008. In: VIEIRA, C.; PAULA JÚNIOR, J. \& BORÉM. A. (eds.). Feijão. $2^{\mathrm{a}}$ ed. UFV. Viçosa. p.87114.

BANZATO, D.A. \& KRONKA, S.N. 2006. Experimentação agrícola. $4^{\text {a }}$ ed. FUNEP. Jaboticabal.

BARBOSA, F.R. \& GONZAGA, A.C.O. 2012. Informações técnicas para o cultivo do feijoeiro-comum na Região Central-Brasileira: 2012-2014. Santo Antônio de Goiás, GO: Embrapa Arroz e Feijão. 247p. (Embrapa Arroz e Feijão. Documentos, 272).

BEHLAU, F.; NUNES L.M. \& LEITE JUNIOR, R.P. 2006. Meio de cultura semi seletivo para detecção de Curtobacterium flaccumfaciens pv. flaccumfaciens em solo e sementes de feijoeiro. Summa Phytopathologica 32:394-396.

BIANCHINI, A.; MARINGONI, A.C. \& CARNEIRO, S.M.T.P.G. 2005. Doenças do feijoeiro. In: Kimati, H.; Amorim, L.; Rezende, J.A.M; Bergamin Filho, A.; Camargo, L.E. A. (eds.). Manual de Fitopatologia: Doenças das Plantas Cultivadas. $4^{\mathrm{a}}$ ed. Agronômica Ceres. São Paulo. v. 2, p. 333-350.

BLOCK, S. S.1991. Peroxygen compounds. In: BLOCK, S. S. (ed.). Disinfection, sterilization and preservation. $4^{\text {th }}$ ed. Lea Febiger. Philadelphia. p. 167-181. 
BLUM, L.E.B.; MACHADO, J.C. \& NASSER, L.C.B. 2006. Patógenos de sementes. In: Blum, L.E.B.; Cares, J.E.; \& Uesugi, C.H. (eds.). Fitopatologia: estudo das doenças de plantas. 2⿳亠丷厂 ed. Otimismo. Brasília. p.234-241.

BONFIM JÚNIOR, M.F. 2013. Fitonematoides em feijoeiro-comum: ocorrência em regiões do Paraná e São Paulo e interação de cultivares com Pratylenchus brachyurus, Meloidogyne incognita e M. javanica. Tese de Doutorado. Universidade de São Paulo: Escola Superior de Agricultura "Luiz de Queiroz". Piracicaba, Brasil.

BORÉM, A. \& CARNEIRO, J.E.S. 2008. A Cultura. In: VIEIRA, C.; PAULA JÚNIOR, J. \& BORÉM. A. (eds.). Feijão. $2^{\mathrm{a}}$ ed. UFV. Viçosa. p.13-18.

BRADBURY, J.F. 1986. Guide to plant pathogenic bacteria. CAB: International Mycological Institute. London. 322p.

BRASIL. Ministério da Agricultura, Pecuária e Abastecimento. Instrução Normativa ${ }^{\circ}$ 15, de 16 de junho de 2014. Diário Oficial da União, n 114, Seção 1, p. 33-34.

BURLE, M.L.; FONSECA, J.R.; KAMI, J.A. \& GEPTS, P. 2010. Microsatellite diversity and genetic structure among common bean (Phaseolus vulgaris L.) landraces in Brazil, a secondary center of diversity. Theoretical and Applied Genetics. 121:801-813.

CAMARA, R.C. 2008. Transmissão planta - semente de Curtobacterium flaccumfaciens pv. flacumfaciens em cultivares de feijoeiro. Dissertação Mestrado. Faculdade de Ciências Agronômicas, Universidade Estadual Paulista “Júlio de Mesquita Filho”. Botucatu, Brasil.

CARLSON, R.R. \& VIDAVER, A, K. 1982. Taxonomy of Corynebacterium plant pathogens, including a new pathogen of wheat, based on polyacrylamide gel electrophoresis of cellular proteins. International Journal of Systematic Bacteriology. 32:315-326.

CARMO, M.G.F.; CORREA, F.M.; CORDEIRO, E.S.; CARVALHO, A.O. \& ROSSETTO, C.A.V. 2004. Tratamentos de erradicação de Xanthomonas vesicatoria e efeitos sobre a qualidade das sementes de tomate. Horticultura Brasileira, Brasília 22(3): 579-584. 
CHAVARRO, C.A.; LOPEZ, G.C.A. \& LENNE, J.M. 1985. Características y pathogenicidad de Corynebacterium flaccumfaciens (Hedges) Dows. agente causal del marchitamiento bacteriano de Zornia spp. y su efecto en el rendimiento de Z. glaba CIAT 7847 y Phaseolus vulgaris. Acta Agronomica. 35(2):64-79.

CLESCERL, L.S.; GREENBERG, A.E \& EATON, A.D. 2000. Standard methods for the examination of water and wastewater. American Water Works Association. Denver.

COLLINS, M.D. \& JONES, D. 1983. Reclassification of Corynebacterium flaccumfaciens, Corynebacterium betae, Corynebacterium oorti and Corynebacterium poinsettiae in the genus Curtobacterium flaccumfaciens comn. Nov. Journal of General Microbiology. 129: 35453548 .

COMMONWEALTH MYCOLOGICAL INSTITUTE. 1992. Distribution maps of plant disease: map n. 85. $5^{\text {th }}$ ed. Farnhan Royal.

CONAB. Levantamento de Safra. http://www.conab.gov.br/conteudos.php?a=1253\&. Consultado em 15/06/2014.

COOKSEY, D.A. 1993. Copper uptake and resistance in bacteria. Molecular Microbiology $7: 1-5$

COSTA, A.S. \& PARADELA. O. 1972. Evidência adicional sobre a ocorrência de crestamento bacteriano aureolado em feijão no Estado de São Paulo. Revista da Sociedade Brasileira de Fitopatologia. Brasília. 5:97-99.

COSTA, J.G.C. Feijão: Morfologia. AGEITEC: Agência Embrapa de Informação Tecnológica.http://www.agencia.cnptia.embrapa.br/gestor/feijao/arvore/CONTAG01_9_1311 200215101.html. Consultado em 27/07/2014. 
COSTA, J.R.; ARAÚJO, E.R.; BECKER, W.F.; FERREIRA, M.A.S.V. \& QUEZADODUVAL, A.M. 2012. Ocorrência e caracterização do complexo de espécies causadoras da mancha bacteriana do tomateiro no Alto Vale do Rio do Peixe, SC. Tropical Plant Pathology 37(2): 149-154.

COYNE, D.P.; SCHUSTER, M.L. \& AL-YASIRI, S. 1963. Reaction studies of bean species and varieties to common blight and bacterial wilt. Plant Disease Reporter. 47:534-537.

COYNE, D.P. \& SCHUSTER, M.L. 1974. Breeding and genetic studies of tolerance to several bean (Phaseolus vulgaris L.) bacterial pathogens. Euphytica, Dondrecht. 23(3): 651656.

CTSBF - COMISSÃO TÉCNICA SUL-BRASILEIRA DE FEIJÃO. 2012. Informações técnicas para o cultivo de feijão na Região Sul brasileira. $2^{\mathrm{a}}$ ed. Florianópolis: Epagri. 157p.

DAVIS, M.J. \& VIDAVER, A.K. 2001. Coryneform plant pathogens. In: Schaad, N. W., Jones, J. B., Chun, W. (eds.). Plant pathogenic bacteria. $3^{\text {rd }}$ ed. APS Press. St. Paul, USA. p.218-235.

DEUNER, C.C. 2007. Inoculação Artificial e Detecção de Curtobacterium flaccumfaciens pv. flaccumfaciens em sementes de feijão. Tese de Doutorado. Universidade Federal de Lavras. Lavras, Brasil.

DHINGRA, O.D. Teoria da Transmissão de Patógenos Fúngicos por Sementes. 2005. In: Zambolim, L. (ed.). Sementes: qualidade fitossanitária. UFV. Viçosa. p. 75-112.

DHINGRA, O.D.; MUCHOVEJ, J.J. \& CRUZ FILHO, J. da. 1980. Tratamento de sementes: controle de patógenos. UFV. Viçosa. 1980.

DIDONET, A.D. 2003. Fisiologia. In: Moreira, J.A.A.; Stone, L.F. \& Biava, M. (eds.). Feijão: o produtor pergunta, a Embrapa responde. Embrapa Informação Tecnológica. Brasília. p. 21-28. 
DOURADO NETO, D. \& FANCELLI, A.F. 2000. Produção de feijão. Agropecuária. Guaíba.

DUNLEAVY, J.M. 1983. Bacterial tan spot, a new disease of soybeans. Crop Science. 23:473-476.

ESTEFANI, R.C.C.; MIRANDA FILHO, R.J. \& UESUGI, C.H. 2007. Tratamentos térmico e químico de sementes de feijoeiro: eficiência na erradicação de Curtobacterium flaccumfaciens pv. flaccumfaciens e efeitos na qualidade fisiológica das sementes. Fitopatologia Brasileira 32: 434-438.

ESTEFANI, R.C.C. 2004. Termoterapia e quimioterapia no tratamento de sementes de feijoeiro: eficiência na erradicação de Curtobacterium flaccumfaciens pv. flaccumfaciens e efeitos sobre a semente. Dissertação Mestrado. Universidade de Brasília. Brasília, Brasil.

FALEIRO, F.G. 2007. Marcadores genético-moleculares aplicados aos programas de conservação e uso de recursos genéticos. Embrapa Cerrados. Planaltina, DF.

FARIA, L.C.; MELO, L.C.; DEL PELOSO, M.J. \& ABREU. A.F.B. 2005. Base genética na produtividade de grãos do feijoeiro comum no Brasil e no mundo. In: DEL PELOSO, M.J. \& MELO, L.C. (eds.). Potencial de rendimento da cultura do feijoeiro comum. Santo Antônio de Goiás, GO: Embrapa Arroz e Feijão. p.39-70.

FAOSTAT. Food and Agriculture Organization of the United. http://faostat.fao.org/. Consultado em 15/06/2014.

FERNÁNDEZ, F.; GEPTS, P. \& LÓPEZ, M. 1985. Etapas de desarrollo em La planta de frijol. In: LÓPEZ, M.; FERNÁNDEZ, F. \& SCHIINHOVEN, A.van. (eds.). Frijol: Investigación y producción. CIAT. Santiago de Cáli, Colômbia. p.61-78.

FERREIRA, C.M.; SANTOS, M.L.; BRAGA, M.J. \& DEL PELOSO, M.J. 2008. Aspectos Econômicos. In: VIEIRA, C.; PAULA JÚNIOR, J. \& BORÉM. A. (eds.). Feijão. $2^{\text {a }}$ ed. UFV. Viçosa. p.19-40. 
FERREIRA, D.F. 2008. SISVAR: um programa para análises e ensino de estatística. Revista Symposium (Lavras) 6:36-41.

FIALLOS, F.R.G. 2010. Doenças causadas por vírus na cultura de feijoeiro (Phaseolus vulgaris L.). Ciencia y Tecnología 3(2): 1-6.

FRARE, V.C. 2010. Tratamento de sementes de melão (Cucumis melo L.) para o controle de Acidovorax avenae subsp. citrulli. Tese Doutorado. Escola Superior de Agricultura "Luiz de Queiroz”, Universidade de São Paulo. Piracicaba, Brasil.

FRY, W.E. 1982. Principles of plant disease management. Academic. New York.

GEPTS, P. \& DEBOUCK, D. 1991. Origin, domestication, and evolution of the common beaen (Phaseolus vulgaris L.). In: SCHOONHOVEN, A. van \& VOYSET, O. (eds.). Common beans: research for crop improvement. Cali: CIAT. Wallingford: CAB International. p.7-53.

GUIMARÃES, P.M.; PALMANO, S.; SMITH, J.J.; SÁ, M.F.G. \& SADDLER, G.S. 2001. Development of a PCR test for the detection of Curtobacterium flaccumfaciens pv. flaccumfaciens. Antonie van Leeuwenhoek. 80(1):1-10.

GRONDEAU, C. \& SAMSON, R. 1994. A review of thermotherapy to free plant materials from pathogens, especially seeds from bacteria. Critical Reviews in Plant Sciences.13(1): 5775.

HALL, R. 1991. Compendium of bean diseases. APS Press. St.Paul.

HAYWARD, A.C. \& WATERSTON, J.M. 1965. Corynebacterium flaccumfaciens. Commonwealth Mycological Institute. Description of Pathogenic Fungi and Bacteria. Number 43. Kew, Surrew, England. 
HEDGES, F. 1922. A bacterial wilt of bean caused by Bacterium flaccumfaciens nov. sp. Science 55:433-434.

HEDGES, F. 1926. Bacterial wilt of beans (Bacterium flaccumfaciens Hedges) including comparisons with Bacterium phaseoli. Phytopathology. 16:1-21.

HERBES, D.H.; THEODORO, G.F.; MARINGONI, A.C.; PIVA, C.A. \& ABREU, L. 2008. Detecção de Curtobacterium flaccumfaciens pv. flaccumfaciens em sementes de feijoeiro produzidas em Santa Catarina. Tropical Plant Pathology 33:153-156.

HOPKINDS, D.L.; THOMPSON, C.M.; HILGREN, J. \& LOVIC, B. 2006. Wet seed treatment with peroxyacetic acid for the control of bacterial fruit blotch and other seedborne diseases of watermelon. Plant Disease 87:1495-1499.

HSIEH, T.F.; HUANG, H. C.; MÜNDEL, H.-H.; CONNER, R. L.; ERICKSON, R. S.

\& BALASUBRAMANIAN, P. M. 2005. Resistance of common bean (Phaseolus vulgaris) to bacterial wilt caused by Curtobacterium flaccumfaciens pv. flaccumfaciens. Journal of Phytopathology. 153(4):245-249.

HSIEH, T.F.; HUANG, H.C.; MÜNDEL, H.H. \& ERICKSON, R.S. 2003. A Rapid Indoor Technique for Screening Common Bean (Phaseolus vulgaris L.) for Resistance to Bacterial Wilt [Curtobacterium flaccumfaciens pv. flaccumfaciens (Hedges) Collins and Jones]. Revista Mexicana de Fitopatología. 21(3):364-369.

HUANG, H.C.; ERICKSON, R.S.; HSIEH, T.F. 2007a. Control of bacterial wilt of bean (Curtobacterium flaccumfaciens pv. flaccumfaciens) by seed treatment with Rhizobium leguminosarum. Crop Protection. 26:1055-1061.

HUANG, H.C.; MÜNDEL, H.H.; ERICKSON, R.S.; CHELLE, C.D.; BALASUBRAMANIAN, P.M.; KIEHN, F.; CONNER, R.L. 2007b. Resistance of common bean (Phaseolus vulgaris L.) cultivars and germplasm lines to the purple variant of bacterial wilt (Curtobacterium flaccumfaciens pv. flaccumfaciens). Plant Pathology Bull. 16: 91-95. 
HUNT, N. K.; MARIÑAS, B. J. 1999. Inactivation of Escherichia coli with ozone: chemical and inactivation kinetics. Water Research, Kidlington. 33(11): 2633-2641.

IBGE. Levantamento Sistemático da Produção Agrícola. http://www.ibge.gov.br/home/estatistica/indicadores/agropecuaria/lspa/. . Consultado em $15 / 06 / 2014$.

INFORZATO, R. \& MIYASAKA, S. 1963. Sistema radicular do feijoeiro em dois tios de solo do Estado de São Paulo. Bragantia, 22(38):477-481.

INTERNATIONAL SEED TESTING ASSOCIATION (ISTA). 1981. Handbook of vigor test methods. Zurich. Switzerland.

KADO, C.I. \& HESKETT, M.G. 1970. Selective media for isolation of Agrobacterium, Corynebacterium, Erwinia, Pseudomonas and Xanthomonas. Phytopathology 60:969-979.

KARKMKOVA, P. \& BOYADZHIEV, K.H. 1984. The new garden bean cultivar Rositsa. Gardinaska i Lozarka Nauka. 21(3):40-43.

KIM, T.J.; SILVA, J.L.; CHAMUL, R.S. \& CHEN, T.C. 2000. Influence of ozone, hydrogen peroxide, or salt on microbial profile, TBARS and color of channel catfish fillets. Journal of Food Science, Malden. 65(7):1210-1213.

KIRKBY, E.A. \& RÖMHELD, V. 2007. Micronutrientes na fisiologia de plantas: funções, absorção e mobilidade. INPI: Informações Agronômicas 118: 1-24.

KOLCHINSKI, E.M.; SCHUCH L.O.B. \& PESKE S.T. 2006. Crescimento inicial de soja em função do vigor das sementes. Revista Brasileira Agrociência 12(2):163-166.

KRAUSE, W.; RODRIGUES, R. \& LEAL, N.R. 2009. Identificação de fontes de resistência e avaliação de métodos de inoculação de Curtobacterium flaccumfaciens pv. flaccumfaciens em feijão-de-vagem. Ciência e Agrotecnologia. 33:1901-1907. 
KRUPPA, P.C. 1993. Detecção de Xanthomonas campestris pv. vesicatoria em sementes e no interior de frutos de tomateiro pelo uso de meios de culturas semi -seletivos. Dissertação de Mestrado. Universidade Estadual Paulista. Botucatu, Brasil.

LANGLAIS, B.; RECKHOW, D.A. \& BRINK, D.R. 1991. Ozone in water treatment: application and engineering. AWWARF and Lewis Publishers. Chelsea.

LAPOLLI, F. R.; SANTOS, L. F.; HÁSSEMER, M. E. N.; AISSE, M. M. \& PIVELI, R. P. 2003. Desinfecção de efluentes sanitários por meio da ozonização. In. GONÇALVES, R. F. (ed.). Desinfecção de efluentes sanitários, remoção de organismos patógenos e substâncias nocivas: aplicação para fins produtivos como agricultura, aqüicultura e hidropônica. PROSAB. Vitória. p.169-208.

LEITE JÚNIOR, R.P. 2000. Surviving with Citrus Canker in Brazil. In: Proceedings, $9^{\text {th }}$ Congress of the International Society for Citriculture. Orlando. p. 890-896.

LEITE JÚNIOR, R.P.; MENEGUIM, L.; BEHLAU, F.; RODRIGUES, S.R.; BIANCHINI, A. 2001. Ocorrência de Curtobacterium flaccumfaciens pv. flaccumfaciens em feijoeiro no Paraná e Santa Catarina. Fitopatologia Brasileira, 26:303. Suplemento.

LOBO JÚNIOR. 2005. Cultivo do Feijão Irrigado na Região Noroeste de Minas Gerais: Doenças e Métodos de Controle. Embrapa Arroz e Feijão: Sistema de Produção. http://sistemasdeproducao.cnptia.embrapa.br/FontesHTML/Feijao/FeijaoIrrigadoNoroesteMG /doencas.htm. Consultado em 13/06/2014.

LUDWIG, M.P.; SCHUCH, L.O.B; LUCCA FILHO, O.A; AVELAR, S.A.G.; MIELEZRSKI, F.; PANOZZO, L.E.; OLIVO, M. \& SEUS, R. 2008. Desempenho de plantas de feijão originadas de lotes de sementes com diferentes níveis de qualidade fisiológica. Revista da FZVA 15(2): 44-52.

MAGUIRE, J.D. 1962. Speed of germination-aid in selection and evaluation for seedling emergence and vigor. Crop Science 2(2): 176-177. 
MACHADO, J.C. 1988. Patologia de sementes: fundamentos e aplicações. Ministério da Educação, ESAL/FAEPE. Brasília, Lavras.

MACHADO, J.C. 2000. Patologia de Sementes: Significado e Atribuições. In: Carvalho, N.M. \& NACAGAWA, J. Sementes: Ciência, Tecnologia e Produção. $4^{\mathrm{a}}$ ed. Funep. Jaboticabal. p. 522-588.

MACHADO, J.C.; WAQUIF, J.M; SANTOS, J.P. \& REICHENBACH, J.W. 2006. Tratamento de sementes no controle de fitopatógenos e pragas. Informe Agropecuário. 27(232):76-87.

MAFFIA, L.A.; CARMO, M.G.F. \& KATSURAYAMA, Y. 1988. In: Seminário sobre pragas e doenças do feijoeiro, 3. Anais. Piracicaba. p.103-126.

MARQUES, E.; UESUGI, C.H.; \& FERREIRA, M.A.S.V. 2009. Sensitivity to copper in Xanthomonas campestris pv. viticola. Tropical Plant Pathology 34(6):406-411.

MARCO, G.M. \& STALL, R.E. 1983. Control of bacterial spot of pepper initiated by strains of Xanthomonas campestris pv. vesicatoria that differ in sensitivity to copper. Plant Disease 67:779-781.

MARINGONI, A.C. 2000. Caracterização de isolados de Curtobacterium flaccumfaciens pv. flaccumfaciens e avaliação da resistência de cultivares de feijoeiro comum à murcha-deCurtobacterium. Tese de Livre Docência. Faculdade de Ciências Agronômicas, Universidade Estadual Paulista "Júlio de Mesquita Filho". Botucatu, Brasil.

MARINGONI A.C.; CAMARA R.C. \& SOUZA V.L. 2006. Semi-selective culture medium for Curtobacterium flaccumfaciens pv. flaccumfaciens isolation from bean seeds. Seed Science \& Technology. 34:117-124.

MARINGONI. A.C. \& CAMARA, R.C. 2006. Curtobacterium flaccumfaciens pv. flaccumfaciens detection in bean seeds using a semi-selective medium. Brazilian Journal of Microbiology. 37:451-455. 
MARINGONI, A.C. \& ROSA, E.F. 1997. Ocorrência de Curtobacterium flaccumfaciens pv. flaccumfaciens em feijoeiro no Estado de São Paulo. Summa Phytopathologica. 23:160-162. McDONALD JUNIOR, M.B. 1980. Vigor test subcommittee report. News Lett. Assoc. Off. Seed Anal. 54(1): 37-80.

MELLO, M.R.F.; SILVEIRA, E.B.; VIANA I.O.; GUERRA, M.L. \& MARIANO R.L.R. 2011. Uso de antibióticos e leveduras para controle da podridão-mole em couve-chinesa. Horticultura Brasileira 29: 78-83.

MENEGUIM, L., RINALDI, D.A.M.F., SANTOS, A.C.A., RODRIGUES, L.S., SILVA, M.R.L., CANTERI, M.G. \& LEITE JÚNIOR, R.P. 2007. Sensibilidade de Xanthomonas axonopodis pv. citri ao cobre e mancozeb. Fitopatologia Brasileira 32:247-252.

MENTEN, J.O.M. 1995. Patógenos em Sementes, Detecção, Danos e Controle Químico. Ciba Agro. São Paulo.

MIRANDA FILHO, R.J. 2010. Etiologia, Epidemiologia e Fisiologia da Murcha de Curtobacterium. Tese de Doutorado. Universidade de Brasília. Brasília, Brasil.

MORAES, M.H.D.; FRARE, V.C.; OTTONI, J.; BALANI, D.M.; VAZ MONDO, V.H \& MENTEN, J.O.M. 2010. Avaliação de dois meios de cultura semi-seletivos para a detecção de Curtobacterium flaccumfaciens pv. flaccumfaciens em sementes de feijoeiro. Tropical Plant Pathology. 35:385-389.

NAKAJIMA, M.; GOTO, M. \& HIBI, T. 2002. Similarity between copper resistance genes from Pseudomonas syringae pv. actinidiae and P. syringae pv. tomato. Journal of General Plant Pathology 68:68-74.

NASCIMENTO, M. S. 2002. Avaliação comparativa de tratamentos químicos na sanitização de frutas e verduras. Dissertação Mestrado. Faculdade de Ciências Farmacêuticas, Universidade Estadual Paulista Júlio de Mesquita Filho. Araraquara, Brasil. 
NIKITINA, K.V.; BUDANOVA, V.I.; STEPANOVA, S.I. \& YASKINA, O.S. 1980. Rapid method of evaluating resistance to bacterial diseases in lupin and Phaseolus. Selektsiya i Semenovodstvo URSS, Moscow. 5:22-23.

NUNES, L.M.; BEHLAU, F. \& LEITE, R.P. 2004. Especificidade de primers para identificação e detecção de Curtobacterium flaccumfaciens pv. flaccumfaciens por PCR. Fitopatologia Brasileira. 29:243. Suplemento.

OLIVEIRA, J.R. 1995. Detecção de Xanthomonas campestris pv. vesicatoria em sementes de tomateiro. Tese de Doutorado. Universidade Federal de Viçosa. Viçosa, Brasil.

OLIVEIRA, J.R.; MOURA, A.B. \& SOUZA, R.M. 2005. Transmissão e controle de fitobactérias em sementes. In: Zambolim, L. (ed.). Sementes: qualidade fitossanitária. UFV. Viçosa. p. 113-134.

PASCUAL, A. LLORCA, L. CANUT, A. 2007. Use ozone in food industries for reducing the environmental impact of cleaning and disinfection activities. Trends in Food Science \& Technology. 18:29-35.

PAULA JÚNIOR, T.J. \& ZAMBOLIM, L. 2008. Doenças. In: VIEIRA, C.; PAULA JÚNIOR, J. \& BORÉM. A. (eds.). Feijão. $2^{\mathrm{a}}$ ed. UFV. Viçosa. p.359-414.

PIRANI, S. Application of ozone in food industries. 2011. Tese de Doutorado.Universita degli Studi di Milano. Milão, Itália.

PHANG, P.D.; GUTENMAHER, P. \& MOELA, I. 1974. Resistance to bacterial rots in some French bean. Lucrari Stiintifice. 17:45- 48.

POPINIGIS, F. 1985. Fisiologia da semente. Agiplan. Brasília.PORTES, T.A. 1988. Ecofisiologia. In: ZIMMERMANN. M.J.de O.; ROCHA, M. \& YAMADA, T. (eds.). Cultura do feijoeiro: fatores que afetam a produtividade. Associação Brasileira para Pesquisa da Potassa e do Fosfato. Piracicaba. p.125-156. 
PRESTES, E. B. 2007. Avaliação da eficiência do ozônio como sanitizante em hortaliças folhosas minimamente processadas. Tese de Doutorado. Universidade Estadual de Campinas. Campinas, Brasil.

QUEZADO-DUVAL, A.M.; GAZZOTO FILHO, A.; LEITE JÚNIOR, R.P. \& CAMARGO, L.E.A. 2003. Sensibilidade a cobre, estreptomicina e oxitetraciclina em Xanthomonas spp. associadas à mancha-bacteriana do tomate para processamento industrial. Horticultura Brasileira 21:670-675.

RAT, B. 1987. Control of seed borne bacteria. In: NASSER, L.C.B.; ETZEL, M.M. \& FERNANDES, J.M. Proceedings; seed pathology international advanced course. ABRATES. Passo Fundo, Brasília. p.258-263.

RAVA, C. A.; COSTA, J. G. C.; FOnSECA, J. R. \& SAlGADO, A. L. 2003. Fontes de resistência à antracnose, crestamento bacteriano comum e murcha de curtobacterium em coletas de feijoeito comum. Revista Ceres. 50 (292): 797-802.

RAVA, C.A.; COSTA, J.G.C. \& ZIMMERMANN, F.J.P. 2004. Variabilidade de reação em plantas cultivar pérola de feijoeiro comum inoculadas com Curtobacterium flaccumfaciens pv. flaccumfaciens. 29:63. Suplemento.

REZENDE, A.M.F.A. 2006. Estudo sobre a resistência genética e produtos químicos no controle da bacteriose da goiabeira (Psidium guajava) causada por Erwinia psidii. Dissertação Mestrado. Universidade de Brasília. Brasília, Brasil.

RICE, R.G \& NETZER, A. 1982. Handbook of Ozone Technology and Applications. Ann Arbor Science. Michigan.

RICE, R. G.; ROBSON, C. M.; MILLER, G. W. \& HILL, A. B. 1981.Uses of ozone in drinking water treatment. Journal of the American Water Works Association. 73(1):44-47. 
RIBEIRO, R.L.D.; HAGEDORN, D.J.; DURBIN, R.D. \& UCHYTIL, T.F. 1979. Characterization of the bacterium inciting bean wildfire in Brazil. Phytopathology 69:208212.

ROBBS, C.F. 1954. A bacteriose do feijoeiro (Phaseolus vulgaris L.) no Distrito Federal. Agronomia. 12:231-233.

RODRIGUES, R.B.; SILVA JÚNIOR, T.A.F. \& MARINGONI A.C. 2006. Efeito da aplicação de lodo de esgoto na severidade da murcha-de-curtobacterium em feijoeiro. Summa Phytopathologica 31:82-84.

ROSOLEM, C.A.; MARUBAYASHI, O.M. 1994. Seja o doutor do seu feijoeiro. Informações Agronômicas 68: 1-16.

ROZADO, A.F.; FARONI, L.R. da.; URRUCHI, W.M.I.; GUEDES, R.N.C. \& PAES, J.L. 2008. Aplicação de ozônio contra Sitophilus zeamais e Tribolium castaneum em milho armazenado. Revista Brasileira de Engenharia Agrícola e Ambiental 12:282-285.

RUSSEL, A. D.; HUGO, W. B. \& AVLIFFE, G. A. J. 1999. Principles and practice of disinfection, preservation and sterilization. $3^{\text {rd }}$ ed. Oxford: Blackwell Science.

SAETTLER, A.W. 1991. Diseases caused by bacteria. In: Hall R (ed.). Compendium of bean diseases. APS Press. Saint Paul. p.29-32.

SAETTLER, A.W. \& PERRY, S.K. 1972. Seed-transmited bacterial diseases in michigan navy (pea) beans, Phaseolus vulgaris. Plant Disease Reporter 56:378-381.

SCHUSTER, M.L. 1959. Relation of root-knot nematodes and irrigation water to the incidence and dissemination of bacterial wilt of bean. Plant Disease Reporter. 43(1):25-32.

SALGADO, R.G.D.; MARINGONI, A.C. \& WILCKEN, S.R.S. 2007. Não-interação patogênica entre Curtobacterium flaccumfaciens pv. flaccumfaciens e Meloidogyne incognita raça 2 em feijoeiro. Nematologia Brasileira.30: 202-205. 
SANTOS, J.B. \& GAVILANES, M.L. 2008. Botânica. In: VIEIRA, C.; PAULA JÚNIOR, J. \& BORÉM. A. (eds.). Feijão. $2^{\text {a }}$ ed. UFV. Viçosa. p.41-66. 4

SARTORATO, A.; RAVA, C.A \& FARIA, J.C. 2003. Cultivo do Feijoeiro Comum: Doenças e métodos de controle. Embrapa Arroz e Feijão: Sistema de Produção. http://sistemasdeproducao.cnptia.embrapa.br/FontesHTML/Feijao/CultivodoFeijoeiro/doenca s.htm. Consultado em 15/05/2014.

SCHUCH, L.O.B. 1999. Vigor das sementes e aspectos da fisiologia da produção em aveiapreta (Avena strigosa Schreb.). Tese Doutorado. Faculdade de Agronomia "Eliseu Maciel”, Universidade Federal de Pelotas. Pelotas, Brasil.

SCHUSTER, M.L. 1967. Survival of bean bacterial pathogens in the field and greenhouse under different environmental conditions. Phytopathology. 57:830.

SILVA. C.C. 2005. Cultivo do Feijão Irrigado na Região Noroeste de Minas Gerais: Produção de Sementes. Embrapa Arroz e Feijão: Sistema de Produção. http://sistemasdeproducao.cnptia.embrapa.br/FontesHTML/Feijao/FeijaoIrrigadoNoroesteMG /psementes.htm. Consultado em 13/06/2014.

SILVA, H.T. Feijão Morfologia. Agência de Informação Embrapa. http://www.agencia.cnptia.embrapa.br/Agencia4/AG01/arvore/AG01_9_1311200215101.htm 1. Consultado em 27/07/2014.

SILVA, S.B.; LUVIELMO, M.M.; GEYER, M.C.; \& PRÁ, I. 2011. Potencialidades do uso do ozônio no processamento de alimentos. Semina: Ciências Agrárias, 32(2): 659-682.

SILVA, T.A. 2011. Processo de ozonização dos grãos de trigo: cinética de reação e efeito na qualidade destes e da farinha. Dissertação Mestrado. Universidade Federal de Viçosa. Viçosa, Brasil. 
SILVA, V.L. \& LOPES, C.A. 1995. Isolados de Pseudomonas syringae pv. tomato resistentes a cobre em tomateiros pulverizados com fungicidas cúpricos. Fitopatologia Brasileira 20: 8589.

SILVA JÚNIOR, T.A.F. 2011. Curtobacterium flaccumfaciens pv. flaccumfaciens: sobrevivência, gama de hospedeiras e efeito do pré-plantio de aveia e trigo na ocorrência da doença. Tese de Doutorado. Universidade Estadual Paulista "Julio de Mesquita Filho". Botucatu, Brasil.

SILVEIRA, I.C.T. 2004. Cloro e ozônio aplicados à desinfecção de efluente hospitalar tratado em contadores biológicos rotatórios, com avaliação de efeitos tóxicos em Daphnia similis. Tese de Doutorado. Universidade do Rio Grande do Sul. Porto Alegre, Brasil.

SINGH, S.P. 2001. Broadenig the genetic base of commom bean cultivars: a review. Crop Science. 41(6):1659-1675.

SOARES, R.M.; FANTINATO, G.G.P.; DARBEN, L.M.; MARCELINO GUIMARÃES, F.C.; SEIXAS, C.D.S. \& CARNEIRO, G.E.S. 2013. First report of Curtobacterium flaccumfaciens pv. flaccumfaciens on soybean in Brazil. Tropical Plant Pathology. 38(5):452454.

SOARES, R.M.; MARINGONI, A.C. \& LIMA, G.P.P. 2004. Ineficiência de acibenzolar-smethyl na indução de resistência de feijoeiro comum à murcha de curtobacterium. Fitopatologia Brasileira. 29:373-377.

SOUZA, J.B. 2006. Avaliação de métodos para desinfecção de água, empregando cloro, ácido peracético, ozônio e o processo de desinfecção combinado ozônio/cloro. Tese Doutorado. Universidade de São Paulo. São Carlos, Brasil.

SOUZA, V.L.; MARINGONI, A.C.; CARBONELL, S.A.M. \& ITO, M.F. 2006. Resistência genética em genótipos de feijoeiro a Curtobacterium flaccumfaciens pv. flaccumfaciens. Summa Phytopathologica. 32(4):339-344. 
SREBERNICH, S.M. 2007. Utilização do dióxido de cloro e do ácido peracético como substitutos do hipoclorito de sódio na sanitização do cheiro-verde minimamente processado. Ciência e Tecnologia de Alimentos. 27(4): 744-750.

TANAKA, M.A.S. \& MACHADO, J.C. 1985. Patologia de Sementes. Informe Agropecuário. 11(122):76-87.

TAYLOR, J.D. \& DUDLEY, C.L. 1977. Seed treatment for the control of halo blight of beans (Pseudomonas phaseolicola). Annals of Applied Biology 85:223-232.

TEGLI, S.; SERENI, A. \& SURICO, G. 2002. PCR - based assay for the detection of Curtobacterium flaccumfaciens pv. flaccumfaiens in bean seeds. Letters in Applied Microbiology. 35:331-337.

THEODORO, G.F.; HERBES, D.H. \& MARINGONI, A. C. 2007. Fontes de resistência à murcha-de-curtobacterium em cultivares locais de feijoeiro, coletadas em Santa Catarina. Ciência e Agrotecnologia. 31(5):333-339.

THEODORO, G.F.; CORREIA, H.C. \& CHUMPATI, A.A. 2011. Avaliação da transmissão de Xanthomonas axonopodis pv. malvacearum via semente-algodoeiro em condições de campo, no cerrado sul-mato-grossense. Bioscience Journal 27(5):701-705.

THEODORO, G, F. \& MARINGONI, A.C. 2004. Distribuição de Curtobacterium flaccumfaciens pv. flaccumfaciens em lavouras de feijoeiro comum no Estado de Santa Catarina. Fitopatologia Brasileira. 29:37. Suplemento.

THEODORO, G.F. \& MARINGONI, A.C. 2006a. Efeito de doses de nitrogênio na severidade da murcha-de-curtobacterium em cultivares de feijoeiro comum. Summa Phytopathologica. 32:131-138.

THEODORO, G.F. \& MARINGONI, A.C. 2006b. Efeito de doses de potássio na severidade da murcha-de-curtobacterium em cultivares de feijoeiro comum. Summa Phytopathologica. 32:139-146. 
TIWARI, B.K. \& RICE, R.G. (2012). Regulatory and Legislative Issues. In: O’donnel, C., Tiwari, B.K., Cullen, P.J. \& Rice, R.G. (eds.). Ozone in food processing. Wiley-Blackwell. p.7-17.

TORRES, G.C., LENNE, J.M., VICTORIA, J.I. \& LOZANO, J.C. 1982. Bacterial wilt of Zornia spp. caused by Corynebacterim flaccumfaciens. In: International Conference on Plant Pathogenic Bacteria, 5, 1982, Cali. Anais. Cali: CIAT, p. 74-79.

UESUGI, C.H., BARBOSA, L.V. \& REZENDE, A.M. 2005. Sensibilidade de isolados de Curtobacterium flaccumfaciens pv. flaccumfaciens a diferentes formulações cúpricas. Fitopatologia Brasileira 30:S68. Suplemento.

UESUGI, C. H; FREITAS, M. A. \& MENEZES, J. R. 2003. Ocorrência de Curtobacterium flaccumfaciens pv. flaccumfaciens em feijoeiro, em Goiás e no Distrito Federal. Fitopatologia Brasileira. 28(3): 324, 2003.

USEPA - United States Environmental Protection Agency. 1999. Wastewater Technology Fact Sheet Ozone Disinfection. 1999. http://www.epa.gov/npdes/pubs/ozon.pdf. Consultado em: 30/09/2014.

VALENTINI, G.; GUIDOLIN, A.F.; BALDISSERA, J.N. da C. \& COIMBRA, J.L.M. 2010. Curtobacterium flaccumfaciens pv. flaccumfaciens: etiologia, detecção e medidas de controle. Biotemas. 23 (4):1-8. Revisão.

VENETTE, J.R., LAMPRA, R.S. \& GROSS, P.L. 1995. First report of bean bacterial wilt caused by Curtobacterium flaccumfaciens subsp. flaccumfaciens in North Dakota. Plant Disease 79:966.

VIEIRA, M.G.G.C. 1988. Aspectos da integração, tecnologia e sanidade em estudos de sementes. In: III SIMPÓSIO BRASILEIRO DE PATOLOGIA DE SEMENTES. Lavras. Fundação Cargill. Campinas. p.48-57. 
VIEIRA, R.D. \& KRZYZANOWSKI, F.C. 1999. Teste de condutividade elétrica. In: Krzyzanowski, F.C.; Vieira, R.D. \& Franca Neto, J.B. Vigor de sementes; conceitos e testes. ABRATES. Londrina. p.4-20.

VILHORDO, B.W. BURIN, M.E. \& GANDOLFI, V.H. 1988. Morfologia. In: ZIMMERMANN. M.J.de O.; ROCHA, M. \& YAMADA, T. (eds.). Cultura do feijoeiro: fatores que afetam a produtividade. Associação Brasileira para Pesquisa da Potassa e do Fosfato. Piracicaba. p.87-124.

VOLOUDAKIS, A.E.; REIGNIER, T.M. \& COOKSEY D.A. 2005. Regulation of resistance to copper in Xanthomonas axonopodis pv. vesicatoria. Applied and Environmental Microbiology 71:792-789.

WENDLAND, A.; ALENCAR, N. E.; MELO, L. C.; COSTA, J. G. C. da; DEL PELOSO, M. J.; PEREIRA, H. S.; FARIA, L. C. de; CÔRTES, M. V. de C. B. \& BRODANI, R.P.V. 2008. Padrão de Sintomas de Isolados de Curtobacterium flaccumfaciens pv. flaccumfaciens em Dois Genótipos de Feijoeiro Comum. 2008. Santo Antônio de Goiás, GO: Embrapa Arroz e Feijão. 19p. (Embrapa Arroz e Feijão. Boletim de Pesquisa e Desenvolvimento, 33).

YOUNG, J.M.; SADDLER, G.S.; TAKIKAWA, Y.; DE BOER, S.H.; VAUTERIN, L.; GARDAN, L.; GVOZDYAK, R. I. \& STEAD, D.E. 1966. Names of Plant Phathogenic Bacteria 1864-1995. Review of Plant Pathology. 75:721-763.

ZAUMEYER, W.J. \& THOMAS, H.R. 1957. A monografic study of bean disease and methods of their control. U.S. Departament Agriculture Thechnical Bulletin. 868:84-88.

ZEVENHUIZEN, L.P.T.M.; DOLFING J.; ESHUIS E.J. \& SCHOLTERN KOERSELMAN, J. 1979. Inhibitory effects of cooper on bacteria related to the free ion concentration. Microbial Ecology 5:139-146. 
ANEXOS 


\section{ANEXO 1. MEIOS DE CULTURA UTILIZADOS}

Anexo 1.1. Meio 523 (Kado \& Heskett, 1970).

Sacarose......................................... 10,0 g

Caseína hidrolisada.......................... $8,0 \mathrm{~g}$

Extrato de levedura.......................... 4, $0 \mathrm{~g}$

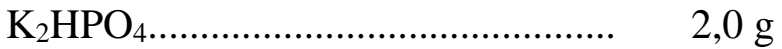

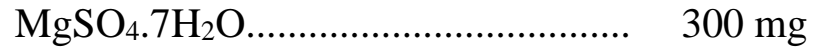

Ágar.............................................. 20,0 g

Água destilada (q.s.p)..................... 1000 mL

Anexo 1.2. Meio CYE-glycerol (Zevenhuizen et al ., 1979).

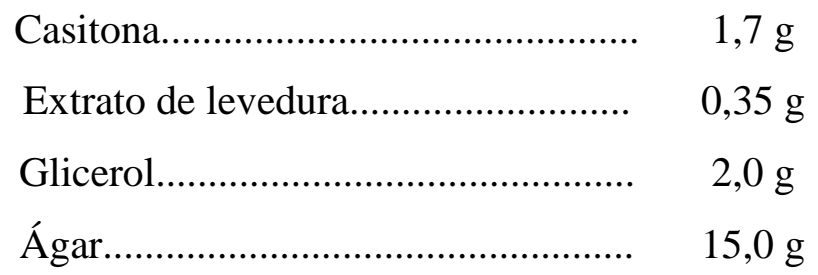

Água destilada (q.s.p)..................... 1000 mL 
ANEXO 2. DADOS REFERENTES AOS TESTES DE SENSIBILIDADE IN VITRO DE Curtobacterium flaccumfaciens pv. flaccumfaciens, ISOLADO UnB 1736 AO COBRE.

Anexo 2.1. Número médio de colônias (UFC/mL) de Curtobacterium flaccumfaciens pv. flaccumfaciens, isolado UnB 1376, observado "in vitro" em meio CYE-glycerol contendo produtos cúpricos em diferentes concentrações.

Concentração $\mathrm{Cu}^{++} \mu \mathrm{g} / \mathrm{mL}$

Princípio Ativo

\begin{tabular}{llllllll}
\hline 0 & 10 & 20 & 30 & 40 & 50 & 100 & 200
\end{tabular}

Hidróxido de Cobre 1360 1096

936

0

0

0

0

0

Oxicloreto de Cobre

1344

1320

564

156

60

0

0

0

Óxido Cuproso

114

836

0

1740

1388

0

0

0

0

0

0 


\section{ANEXO 3. ANÁLISES DE VARIÂNCIA}

Efeito dos diferentes tratamentos de sementes na erradicação de Curtobacterium flaccumfaciens pv. flaccumfaciens.

\section{Variável analisada: PORCENTAGEM DE SEMENTES CONTAMINADAS}

\begin{tabular}{|c|c|c|c|c|c|}
\hline FV & GL & $\mathrm{SQ}$ & $\mathrm{QM}$ & FC & $\operatorname{Pr}>\mathrm{FC}$ \\
\hline $\begin{array}{l}\text { TRATAMENTO } \\
\text { erro }\end{array}$ & $\begin{array}{r}7 \\
16\end{array}$ & $\begin{array}{r}17266.311133 \\
415.140867\end{array}$ & $\begin{array}{r}2466.615876 \\
25.946304\end{array}$ & 95.066 & 0.0000 \\
\hline Total corrigido & 23 & 17681.452000 & & & \\
\hline $\begin{array}{l}\mathrm{CV} \quad(\%)= \\
\text { Média geral: }\end{array}$ & $\begin{array}{c}8.57 \\
59.4450000\end{array}$ & Número d & ervações: & 24 & \\
\hline
\end{tabular}

Variável analisada: UFC/100 LL

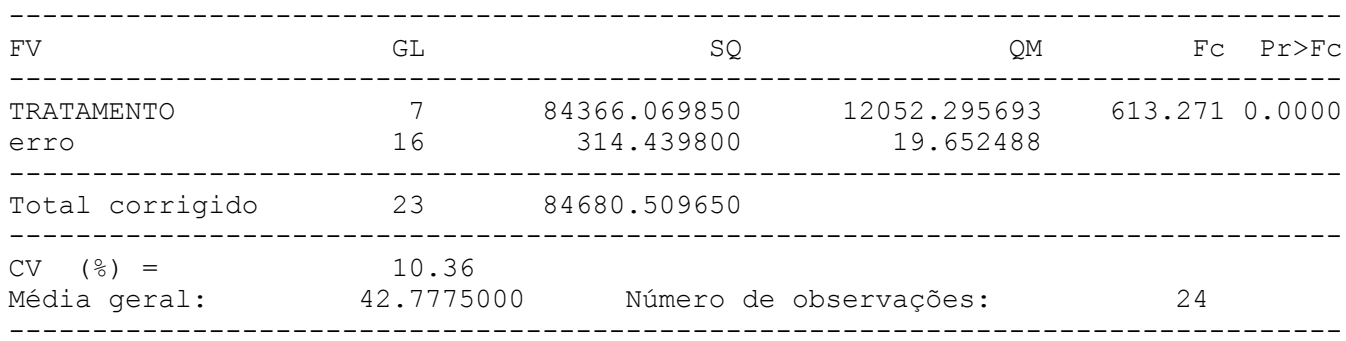




\section{EXPERIMENTO DE CAMPO}

\section{Variável analisada: EMERGÊNCIA EM CAMPO}

TABELA DE ANÁLISE DE VARIÂNCIA

\begin{tabular}{|c|c|c|c|c|c|}
\hline FV & GL & SQ & $\mathrm{QM}$ & $\mathrm{FC}$ & $\operatorname{Pr}>\mathrm{FC}$ \\
\hline SEMENTE & 4 & 991.018456 & 247.754614 & 15.516 & 0.0000 \\
\hline TRATAMENTO & 7 & 3626.875708 & 518.125101 & 32.448 & 0.0000 \\
\hline SEMENTE* TRATAMENTO & 28 & 187.157374 & 6.684192 & 0.419 & 0.9953 \\
\hline $\mathrm{BLOCO}$ & 3 & 450.441362 & 150.147121 & 9.403 & 0.0000 \\
\hline erro & 117 & 1868.235838 & 15.967828 & & \\
\hline Total corrigido & 159 & 7123.728737 & & & \\
\hline $\begin{array}{l}\text { CV }\left(\frac{\circ}{\circ}\right)= \\
\text { Média geral: }\end{array}$ & $\begin{array}{c}4.72 \\
84.7343750\end{array}$ & Número d & rvações: & 160 & \\
\hline
\end{tabular}

Análise do desdobramento de SEMENTE dentro de cada nível de:

TRATAMENTO

\begin{tabular}{|c|c|c|c|c|c|c|}
\hline FV & & GL & $S Q$ & $\mathrm{QM}$ & $\mathrm{EC}$ & $\operatorname{Pr}>\mathrm{FC}$ \\
\hline SEMENTE & $/ 1$ & 4 & 133.273920 & 33.318480 & 2.087 & 0.0865 \\
\hline SEMENTE & 12 & 4 & 116.368080 & 29.092020 & 1.822 & 0.1287 \\
\hline SEMENTE & 13 & 4 & 195.186150 & 48.796537 & 3.056 & 0.0194 \\
\hline SEMENTE & $/ 4$ & 4 & 138.597820 & 34.649455 & 2.170 & 0.0762 \\
\hline SEMENTE & $/ 5$ & 4 & 133.751450 & 33.437862 & 2.094 & 0.0855 \\
\hline SEMENTE & 16 & 4 & 138.238930 & 34.559733 & 2.164 & 0.0769 \\
\hline SEMENTE & 17 & 4 & 209.426130 & 52.356532 & 3.279 & 0.0137 \\
\hline SEMENTE & 18 & 4 & 113.333350 & 28.333337 & 1.774 & 0.1381 \\
\hline Erro & & 117 & 1868.235838 & 15.967828 & & \\
\hline
\end{tabular}

Codificação usada para o desdobramento

cod. TRATAMENTO

$1=$ COBRE 2 = CASUGAMICINA 3 = ÁCIDO PERACÉTICO 4 = CLORETOS DE BENZALCÔNIO 5 = VAPOR ETANOL 6

= VAPOR METANOL 7 = OZÔNIO 8 = SEM TRATAMENTO.

Análise do desdobramento de TRATAMENTO dentro de cada nível de:

SEMENTE

TABELA DE ANÁLISE DE VARIÂNCIA

\begin{tabular}{|c|c|c|c|c|c|c|}
\hline FV & & GL & $\mathrm{SQ}$ & $\mathrm{QM}$ & EC & $\operatorname{Pr}>\mathrm{FC}$ \\
\hline TRATAMENTO & $/ 1$ & 7 & 658.677350 & 94.096764 & 5.893 & 0.0000 \\
\hline TRATAMENTO & 12 & 7 & 790.525900 & 112.932271 & 7.072 & 0.0000 \\
\hline TRATAMENTO & 13 & 7 & 751.607672 & 107.372525 & 6.724 & 0.0000 \\
\hline TRATAMENTO & $/ 4$ & 7 & 1071.106972 & 153.015282 & 9.583 & 0.0000 \\
\hline TRATAMENTO & $/ 5$ & 7 & 542.115188 & 77.445027 & 4.850 & 0.0001 \\
\hline Erro & & 117 & 1868.235838 & 15.967828 & & \\
\hline
\end{tabular}

Codificação usada para o desdobramento

COd. SEMENTE

1 = SEMENTE BÁSICA 2 = SEMENTE COM 10\% DE INÓCULO 3 = SEMENTE COM 30\% DE INÓCULO $4=$ SEMENTE COM 50\% DE INÓCULO 5 = SEMENTE NATURALMENTE INFECTADA 
Variável analisada: Índice de Velocidade de Emergência (IVE)

TABELA DE ANÁLISE DE VARIÂNCIA

\begin{tabular}{|c|c|c|c|c|c|}
\hline FV & GL & $S Q$ & $\mathrm{QM}$ & FC & Pr $>$ FC \\
\hline SEMENTE & 4 & 53.966279 & 13.491570 & 10.175 & 0.0000 \\
\hline TRATAMENTO & 7 & 189.765314 & 27.109331 & 20.445 & 0.0000 \\
\hline SEMENTE*TRATAMENTO & 28 & 19.580901 & 0.699318 & 0.527 & 0.9738 \\
\hline $\mathrm{BLOCO}$ & 3 & 11.488062 & 3.829354 & 2.888 & 0.0385 \\
\hline erro & 117 & 155.140863 & 1.325990 & & \\
\hline Total corrigido & 159 & 429.941419 & & & \\
\hline $\begin{array}{l}\text { CV }\left(\frac{\circ}{\circ}\right)= \\
\text { Média geral: }\end{array}$ & $\begin{array}{c}7.15 \\
16.1120625\end{array}$ & Número d & vações: & 160 & \\
\hline
\end{tabular}

Análise do desdobramento de SEMENTE dentro de cada nível de:

TRATAMENTO

\begin{tabular}{|c|c|c|c|c|c|c|}
\hline FV & & GL & $\mathrm{SQ}$ & $Q \mathrm{M}$ & FC & $\operatorname{Pr}>\mathrm{FC}$ \\
\hline SEMENTE & $/ 1$ & 4 & 6.773920 & 1.693480 & 1.277 & 0.2823 \\
\hline SEMENTE & 12 & 4 & 3.604870 & 0.901218 & 0.680 & 0.6069 \\
\hline SEMENTE & 13 & 4 & 4.707330 & 1.176832 & 0.888 & 0.4731 \\
\hline SEMENTE & $/ 4$ & 4 & 10.110650 & 2.527662 & 1.906 & 0.1135 \\
\hline SEMENTE & $/ 5$ & 4 & 9.071980 & 2.267995 & 1.710 & 0.1518 \\
\hline SEMENTE & 16 & 4 & 7.132530 & 1.783133 & 1.345 & 0.2569 \\
\hline SEMENTE & 17 & 4 & 25.420730 & 6.355182 & 4.793 & 0.0013 \\
\hline SEMENTE & 18 & 4 & 6.725170 & 1.681293 & 1.268 & 0.2859 \\
\hline Erro & & 117 & 155.140863 & 1.325990 & & \\
\hline
\end{tabular}

Codificação usada para o desdobramento

cod. TRATAMENTO

$1=$ COBRE 2 = CASUGAMICINA 3 = ÁCIDO PERACÉTICO 4 = CLORETOS DE BENZALCÔNIO $5=$ VAPOR ETANOL 6 = VAPOR METANOL 7 = OZÔNIO 8 = SEM TRATAMENTO.

Análise do desdobramento de TRATAMENTO dentro de cada nível de:

SEMENTE

\begin{tabular}{|c|c|c|c|c|c|c|}
\hline FV & & GL & $\mathrm{SQ}$ & $\mathrm{QM}$ & $\mathrm{EC}$ & $\operatorname{Pr}>F_{C}$ \\
\hline TRATAMENTO & $/ 1$ & 7 & 36.893347 & 5.270478 & 3.975 & 0.0006 \\
\hline TRATAMENTO & 12 & 7 & 37.225300 & 5.317900 & 4.011 & 0.0006 \\
\hline TRATAMENTO & 13 & 7 & 30.545672 & 4.363667 & 3.291 & 0.0031 \\
\hline TRATAMENTO & $/ 4$ & 7 & 67.440800 & 9.634400 & 7.266 & 0.0000 \\
\hline TRATAMENTO & $/ 5$ & 7 & 37.241097 & 5.320157 & 4.012 & 0.0006 \\
\hline Erro & & 117 & 155.140863 & 1.325990 & & \\
\hline
\end{tabular}

Codificação usada para o desdobramento

cod. SEMENTE

1 = SEMENTE BÁSICA 2 = SEMENTE COM 10\% DE INÓCULO 3 = SEMENTE COM 30\% DE INÓCULO $4=$ SEMENTE COM 50\% DE INÓCULO 5 = SEMENTE NATURALMENTE INEECTADA. 


\section{EXPERIMENTO CASA DE VEGETAÇÃO}

\section{Variável analisada: EMERGÊNCIA DE PLÂNTULAS EM VASO}

TABELA DE ANÁLISE DE VARIÂNCIA

\begin{tabular}{|c|c|c|c|c|c|}
\hline FV & GL & $\mathrm{SQ}$ & $\mathrm{QM}$ & FC & Pr $>$ FC \\
\hline SEMENTE & 1 & 624.875006 & 624.875006 & 6.508 & 0.0142 \\
\hline TRATAMENTO & 7 & 1909.402819 & 272.771831 & 2.841 & 0.0153 \\
\hline SEMENTE * TRATAMENTO & 7 & 112.819519 & 16.117074 & 0.168 & 0.9904 \\
\hline $\mathrm{BLOCO}$ & 3 & 705.111131 & 235.037044 & 2.448 & 0.075 \\
\hline erro & 45 & 4320.597519 & 96.013278 & & \\
\hline Total corrigido & 63 & 7672.805994 & & & \\
\hline $\begin{array}{l}\mathrm{CV} \quad(\%)= \\
\text { Média geral: }\end{array}$ & $\begin{array}{c}11.20 \\
87.4996875\end{array}$ & Número d & fvações: & 64 & \\
\hline
\end{tabular}

Análise do desdobramento de SEMENTE dentro de cada nível de:

TRATAMENTO

\begin{tabular}{|c|c|c|c|c|c|c|}
\hline FV & & GL & $\mathrm{SQ}$ & $\mathrm{QM}$ & FC & $\operatorname{Pr}>\mathrm{FC}$ \\
\hline SEMENTE & /1 & 1 & 78.187513 & 78.187513 & 0.814 & 0.3716 \\
\hline SEMENTE & 12 & 1 & 34.652812 & 34.652812 & 0.361 & 0.5510 \\
\hline SEMENTE & 13 & 1 & 175.687512 & 175.687512 & 1.830 & 0.1829 \\
\hline SEMENTE & $/ 4$ & 1 & 138.861112 & 138.861112 & 1.446 & 0.2354 \\
\hline SEMENTE & $/ 5$ & 1 & 78.062512 & 78.062512 & 0.813 & 0.3720 \\
\hline SEMENTE & 16 & 1 & 2.173613 & 2.173613 & 0.023 & 0.8811 \\
\hline SEMENTE & 17 & 1 & 175.781250 & 175.781250 & 1.831 & 0.1828 \\
\hline SEMENTE & 18 & 1 & 54.288200 & 54.288200 & 0.565 & 0.4560 \\
\hline Erro & & 45 & 4320.597519 & 96.013278 & & \\
\hline
\end{tabular}

Codificação usada para o desdobramento

cod. TRATAMENTO

$1=$ COBRE 2 = CASUGAMICINA 3 = ÁCIDO PERACÉTICO 4 = CLORETOS DE BENZALCÔNIO 5 = VAPOR ETANOL 6

= VAPOR METANOL 7 = OZÔNIO 8 = SEM TRATAMENTO.

Análise do desdobramento de TRATAMENTO dentro de cada nível de:

SEMENTE

\begin{tabular}{|c|c|c|c|c|c|}
\hline FV & GL & $\mathrm{SQ}$ & $\mathrm{QM}$ & $\mathrm{FC}$ & $\operatorname{Pr}>\mathrm{FC}$ \\
\hline TRATAMENTO & $/ 1$ & 833.208387 & 119.029770 & 1.240 & 0.3014 \\
\hline TRATAMENTO & 12 & 1189.013950 & 169.859136 & 1.769 & 0.1170 \\
\hline Erro & 45 & 4320.597519 & 96.013278 & & \\
\hline
\end{tabular}

Codificação usada para o desdobramento

COd. SEMENTE

1 = SEMENTE BÁSICA 2 = SEMENTE INOCULADA 
Variável analisada: IVE

\begin{tabular}{|c|c|c|c|c|c|}
\hline FV & GL & SQ & $\mathrm{QM}$ & $\mathrm{FC}$ & $\mathrm{Pr}>\mathrm{FC}$ \\
\hline SEMENTE & 1 & 1.081600 & 1.081600 & 5.555 & 0.0228 \\
\hline TRATAMENTO & 7 & 3.987500 & 0.569643 & 2.926 & 0.0130 \\
\hline SEMENTE*TRATAMENTO & 7 & 0.379950 & 0.054279 & 0.279 & 0.9590 \\
\hline BLOCO & 3 & 1.049325 & 0.349775 & 1.796 & 0.1614 \\
\hline erro & 45 & 8.762025 & 0.194712 & & \\
\hline otal corrigido & 63 & 15.260400 & & & \\
\hline $\begin{array}{l}\mathrm{CV}\left(\frac{\circ}{\circ}\right)= \\
\text { Média geral: }\end{array}$ & $\begin{array}{l}13.33 \\
3.3100000\end{array}$ & Número d & ações: & 64 & \\
\hline
\end{tabular}

Análise do desdobramento de SEMENTE dentro de cada nível de:

TRATAMENTO

TABELA DE ANÁLISE DE VARIÂNCIA

\begin{tabular}{|c|c|c|c|c|c|c|}
\hline FV & & GL & $S Q$ & $\mathrm{QM}$ & FC & $\operatorname{Pr}>\mathrm{FC}$ \\
\hline SEMENTE & $/ 1$ & 1 & 0.061250 & 0.061250 & 0.315 & 0.5777 \\
\hline SEMENTE & 12 & 1 & 0.037813 & 0.037813 & 0.194 & 0.6616 \\
\hline SEMENTE & 13 & 1 & 0.352800 & 0.352800 & 1.812 & 0.1850 \\
\hline SEMENTE & $/ 4$ & 1 & 0.043513 & 0.043513 & 0.223 & 0.6387 \\
\hline SEMENTE & $/ 5$ & 1 & 0.189112 & 0.189112 & 0.971 & 0.3296 \\
\hline SEMENTE & 16 & 1 & 0.014450 & 0.014450 & 0.074 & 0.7865 \\
\hline SEMENTE & $/ 7$ & 1 & 0.649800 & 0.649800 & 3.337 & 0.0744 \\
\hline SEMENTE & 18 & 1 & 0.112813 & 0.112813 & 0.579 & 0.4505 \\
\hline Erro & & 45 & 8.762025 & 0.194712 & & \\
\hline
\end{tabular}

Codificação usada para o desdobramento cod. TRATAMENTO

1 = COBRE 2 = CASUGAMICINA 3 = ÁCIDO PERACÉTICO 4 = CLORETOS DE BENZALCÔNIO 5 = VAPOR ETANOL 6 = VAPOR METANOL 7 = OZÔNIO 8 = SEM TRATAMENTO.

Análise do desdobramento de TRATAMENTO dentro de cada nível de:

SEMENTE

\begin{tabular}{|c|c|c|c|c|c|}
\hline FV & GL & $\mathrm{SQ}$ & $Q \mathrm{M}$ & FC & Pr $>$ FC \\
\hline TRATAMENTO & $/ 1$ & 1.424350 & 0.203479 & 1.045 & 0.4137 \\
\hline TRATAMENTO & 12 & 2.943100 & 0.420443 & 2.159 & 0.0561 \\
\hline Erro & 45 & 8.762025 & 0.194712 & & \\
\hline
\end{tabular}

Codificação usada para o desdobramento COd. SEMENTE

1 = SEMENTE BÁSICA 2 = SEMENTE INOCULADA 
Variável analisada: PESO DE MATÉRIA VERDE DE PARTE AÉREA (15 DAS)

TABELA DE ANÁLISE DE VARIÂNCIA

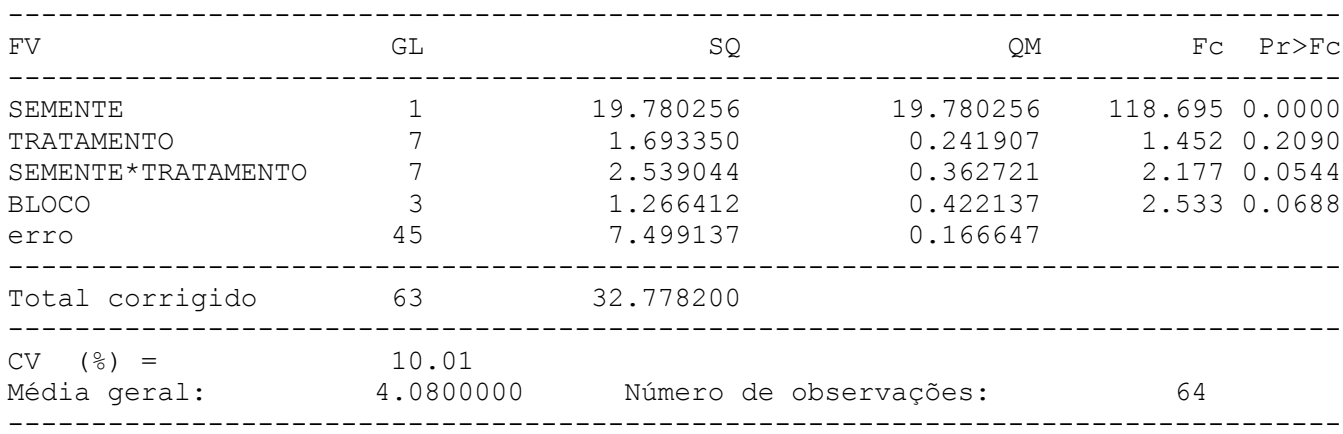

Análise do desdobramento de SEMENTE dentro de cada nível de:

TRATAMENTO

\begin{tabular}{|c|c|c|c|c|c|c|}
\hline FV & & GL & $S Q$ & $\mathrm{QM}$ & FC & $\operatorname{Pr}>\mathrm{FC}$ \\
\hline SEMENTE & $/ 1$ & 1 & 1.540012 & 1.540012 & 9.241 & 0.0039 \\
\hline SEMENTE & 12 & 1 & 2.464200 & 2.464200 & 14.787 & 0.0004 \\
\hline SEMENTE & $/ 3$ & 1 & 3.328200 & 3.328200 & 19.971 & 0.0001 \\
\hline SEMENTE & $/ 4$ & 1 & 1.575313 & 1.575313 & 9.453 & 0.0036 \\
\hline SEMENTE & $/ 5$ & 1 & 2.475313 & 2.475313 & 14.854 & 0.0004 \\
\hline SEMENTE & 16 & 1 & 0.288800 & 0.288800 & 1.733 & 0.1947 \\
\hline SEMENTE & 17 & 1 & 4.004450 & 4.004450 & 24.029 & 0.0000 \\
\hline SEMENTE & 18 & 1 & 6.643012 & 6.643012 & 39.863 & 0.0000 \\
\hline Erro & & 45 & 7.499137 & 0.166647 & & \\
\hline
\end{tabular}

Codificação usada para o desdobramento

cod. TRATAMENTO

$1=$ COBRE 2 = CASUGAMICINA 3 = ÁCIDO PERACÉTICO 4 = CLORETOS DE BENZALCÔNIO 5 = VAPOR ETANOL 6

= VAPOR METANOL 7 = OZÔNIO 8 = SEM TRATAMENTO.

Análise do desdobramento de TRATAMENTO dentro de cada nível de:

SEMENTE

TABELA DE ANÁLISE DE VARIÂNCIA

\begin{tabular}{|c|c|c|c|c|c|}
\hline FV & & GL & $\mathrm{SQ}$ & $\mathrm{QM}$ & $\mathrm{FC} \quad \mathrm{Pr}>\mathrm{FC}$ \\
\hline TRATAMENTO & $/ 1$ & 7 & 1.727622 & 0.246803 & 1.2070 .3186 \\
\hline TRATAMENTO & 12 & 7 & 2.651647 & 0.378807 & 1.8520 .1003 \\
\hline Erro & & 45 & 9.204744 & 0.204550 & \\
\hline
\end{tabular}

Codificação usada para o desdobramento

cod. SEMENTE

1 = SEMENTE BÁSICA 2 = SEMENTE INOCULADA 
Variável analisada: NÚMERO DE TRIFÓLIOS (28 DAS)

\begin{tabular}{|c|c|c|c|c|c|}
\hline FV & GL & $\mathrm{SQ}$ & $\mathrm{QM}$ & $\mathrm{FC}$ & Pr $>$ FC \\
\hline SEMENTE & 1 & 2.843439 & 2.843439 & 43.669 & 0.0000 \\
\hline TRATAMENTO & 7 & 0.695136 & 0.099305 & 1.525 & 0.1833 \\
\hline SEMENTE*TRATAMENTO & 7 & 0.538598 & 0.076943 & 1.182 & 0.3324 \\
\hline BLOCO & 3 & 0.276130 & 0.092043 & 1.414 & 0.2512 \\
\hline erro & 45 & 2.930095 & 0.065113 & & \\
\hline otal corrigido & 63 & 7.283398 & & & \\
\hline $\begin{array}{l}\mathrm{CV} \quad\left(\frac{\circ}{0}\right)= \\
\text { Média geral: }\end{array}$ & $\begin{array}{c}9.10 \\
2.8051562\end{array}$ & Número d & ações: & 64 & \\
\hline
\end{tabular}

Análise do desdobramento de SEMENTE dentro de cada nível de:

TRATAMENTO

TABELA DE ANÁLISE DE VARIÂNCIA

\begin{tabular}{|c|c|c|c|c|c|c|}
\hline FV & & GL & $S Q$ & $\mathrm{QM}$ & FC & Pr $>$ FC \\
\hline SEMENTE & $/ 1$ & 1 & 0.031250 & 0.031250 & 0.480 & 0.4920 \\
\hline SEMENTE & 12 & 1 & 0.732050 & 0.732050 & 11.243 & 0.0016 \\
\hline SEMENTE & 13 & 1 & 0.378450 & 0.378450 & 5.812 & 0.0201 \\
\hline SEMENTE & $/ 4$ & 1 & 0.252050 & 0.252050 & 3.871 & 0.0553 \\
\hline SEMENTE & $/ 5$ & 1 & 0.145800 & 0.145800 & 2.239 & 0.1415 \\
\hline SEMENTE & 16 & 1 & 0.195313 & 0.195313 & 3.000 & 0.0901 \\
\hline SEMENTE & $/ 7$ & 1 & 0.588612 & 0.588612 & 9.040 & 0.0043 \\
\hline SEMENTE & 18 & 1 & 1.058513 & 1.058513 & 16.256 & 0.0002 \\
\hline Erro & & 45 & 2.930095 & 0.065113 & & \\
\hline
\end{tabular}

Codificação usada para o desdobramento cod. TRATAMENTO

1 = COBRE 2 = CASUGAMICINA 3 = ÁCIDO PERACÉTICO 4 = CLORETOS DE BENZALCÔNIO 5 = VAPOR ETANOL 6 = VAPOR METANOL 7 = OZÔNIO 8 = SEM TRATAMENTO.

Análise do desdobramento de TRATAMENTO dentro de cada nível de:

SEMENTE

\begin{tabular}{|c|c|c|c|c|c|c|}
\hline FV & & GL & $\mathrm{SQ}$ & $\mathrm{QM}$ & $\mathrm{FC}$ & Pr $>$ FC \\
\hline TRATAMENTO & $/ 1$ & 7 & 0.072447 & 0.010350 & 0.159 & 0.9918 \\
\hline TRATAMENTO & 12 & 7 & 1.161288 & 0.165898 & 2.548 & 0.0267 \\
\hline Erro & & 45 & 2.930095 & 0.065113 & & \\
\hline
\end{tabular}

Codificação usada para o desdobramento

cod. SEMENTE

$1=$ SEMENTE BÁSICA 2 = SEMENTE INOCULADA 
Variável analisada: ALTURA PLANTA (28 DAS)

TABELA DE ANÁLISE DE VARIÂNCIA

\begin{tabular}{|c|c|c|c|c|c|}
\hline FV & GL & $\mathrm{SQ}$ & $\mathrm{QM}$ & FC & $\operatorname{Pr}>\mathrm{FC}$ \\
\hline SEMENTE & 1 & 154.846914 & 154.846914 & 81.795 & 0.0000 \\
\hline TRATAMENTO & 7 & 33.634223 & 4.804889 & 2.538 & 0.0273 \\
\hline SEMENTE*TRATAMENTO & 7 & 18.569223 & 2.652746 & 1.401 & 0.2285 \\
\hline BLOCO & 3 & 8.472280 & 2.824093 & 1.492 & 0.2296 \\
\hline erro & 45 & 85.189595 & 1.893102 & & \\
\hline Total corrigido & 63 & 300.712236 & & & \\
\hline $\begin{array}{l}\mathrm{CV} \quad\left(\frac{\circ}{0}\right)= \\
\text { Média geral: }\end{array}$ & $\begin{array}{c}7.34 \\
18.7379688\end{array}$ & Número d & fvações: & 64 & \\
\hline
\end{tabular}

Análise do desdobramento de SEMENTE dentro de cada nível de:

TRATAMENTO

\begin{tabular}{|c|c|c|c|c|c|c|}
\hline FV & & GL & $\mathrm{SQ}$ & $\mathrm{QM}$ & $\mathrm{FC}$ & $\operatorname{Pr}>\mathrm{FC}$ \\
\hline SEMENTE & /1 & 1 & 9.746113 & 9.746113 & 5.148 & 0.0281 \\
\hline SEMENTE & 12 & 1 & 26.317513 & 26.317513 & 13.902 & 0.0005 \\
\hline SEMENTE & 13 & 1 & 12.525012 & 12.525012 & 6.616 & 0.0135 \\
\hline SEMENTE & $/ 4$ & 1 & 13.338613 & 13.338613 & 7.046 & 0.0109 \\
\hline SEMENTE & $/ 5$ & 1 & 17.582450 & 17.582450 & 9.288 & 0.0039 \\
\hline SEMENTE & 16 & 1 & 16.791013 & 16.791013 & 8.870 & 0.0047 \\
\hline SEMENTE & $/ 7$ & 1 & 11.162812 & 11.162812 & 5.897 & 0.0192 \\
\hline SEMENTE & 18 & 1 & 65.952613 & 65.952613 & 34.838 & 0.0000 \\
\hline Erro & & 45 & 85.189595 & 1.893102 & & \\
\hline
\end{tabular}

Codificação usada para o desdobramento

cod. TRATAMENTO

$1=$ COBRE 2 = CASUGAMICINA 3 = ÁCIDO PERACÉTICO 4 = CLORETOS DE BENZALCÔNIO 5 = VAPOR ETANOL 6

= VAPOR METANOL 7 = OZÔNIO $8=$ SEM TRATAMENTO.

Análise do desdobramento de TRATAMENTO dentro de cada nível de:

SEMENTE

TABELA DE ANÁLISE DE VARIÂNCIA

\begin{tabular}{|c|c|c|c|c|c|c|}
\hline $\mathrm{FV}$ & & GL & $\mathrm{SQ}$ & $\mathrm{QM}$ & $\mathrm{FC}$ & $\operatorname{Pr}>F_{C}$ \\
\hline TRATAMENTO & $/ 1$ & 7 & 12.957497 & 1.851071 & 0.978 & 0.4588 \\
\hline TRATAMENTO & 12 & 7 & 39.245950 & 5.606564 & 2.962 & 0.0121 \\
\hline Erro & & 45 & 85.189595 & 1.893102 & & \\
\hline
\end{tabular}

Codificação usada para o desdobramento

cod. SEMENTE

1 = SEMENTE BÁSICA 2 = SEMENTE INOCULADA 
Variável analisada: NÚMERO DE VAGENS POR PARCELA

\begin{tabular}{|c|c|c|c|c|c|}
\hline FV & GL & $\mathrm{SQ}$ & $\mathrm{QM}$ & $\mathrm{FC}$ & $\operatorname{Pr}>\mathrm{FC}$ \\
\hline EMENTE & 1 & 2916.000000 & 2916.000000 & 111.593 & 0.0000 \\
\hline RATAMENTO & 7 & 394.500000 & 56.357143 & 2.157 & 0.0565 \\
\hline SEMENTE*TRATAMENTO & 7 & 615.250000 & 87.892857 & 3.364 & 0.0057 \\
\hline $\mathrm{LOCO}$ & 3 & 46.125000 & 15.375000 & 0.588 & 0.6258 \\
\hline rro & 45 & 1175.875000 & 26.130556 & & \\
\hline otal corrigido & 63 & 5147.750000 & & & \\
\hline $\begin{array}{l}\mathrm{V} \quad\left(\frac{\circ}{0}\right)= \\
\text { édia geral: }\end{array}$ & $\begin{array}{c}12.34 \\
41.4375000\end{array}$ & Número d & ervações: & 64 & \\
\hline
\end{tabular}

Análise do desdobramento de SEMENTE dentro de cada nível de:

TRATAMENTO

TABELA DE ANÁLISE DE VARIÂNCIA

\begin{tabular}{|c|c|c|c|c|c|c|}
\hline FV & & GL & $\mathrm{SQ}$ & $\mathrm{QM}$ & FC & $\operatorname{Pr}>F_{C}$ \\
\hline SEMENTE & $/ 1$ & 1 & 288.000000 & 288.000000 & 11.022 & 0.0018 \\
\hline SEMENTE & 12 & 1 & 364.500000 & 364.500000 & 13.949 & 0.0005 \\
\hline SEMENTE & 13 & 1 & 450.000000 & 450.000000 & 17.221 & 0.0001 \\
\hline SEMENTE & $/ 4$ & 1 & 105.125000 & 105.125000 & 4.023 & 0.0509 \\
\hline SEMENTE & $/ 5$ & 1 & 480.500000 & 480.500000 & 18.388 & 0.0001 \\
\hline SEMENTE & 16 & 1 & 15.125000 & 15.125000 & 0.579 & 0.4507 \\
\hline SEMENTE & $/ 7$ & 1 & 578.000000 & 578.000000 & 22.120 & 0.0000 \\
\hline SEMENTE & 18 & 1 & 1250.000000 & 1250.000000 & 47.837 & 0.0000 \\
\hline Erro & & 45 & 1175.875000 & 26.130556 & & \\
\hline
\end{tabular}

Codificação usada para o desdobramento

cod. TRATAMENTO

1 = COBRE 2 = CASUGAMICINA 3 = ÁCIDO PERACÉTICO 4 = CLORETOS DE BENZALCÔNIO 5 = VAPOR ETANOL 6

$=$ VAPOR METANOL 7 = OZÔNIO 8 = SEM TRATAMENTO.

Análise do desdobramento de TRATAMENTO dentro de cada nível de:

SEMENTE

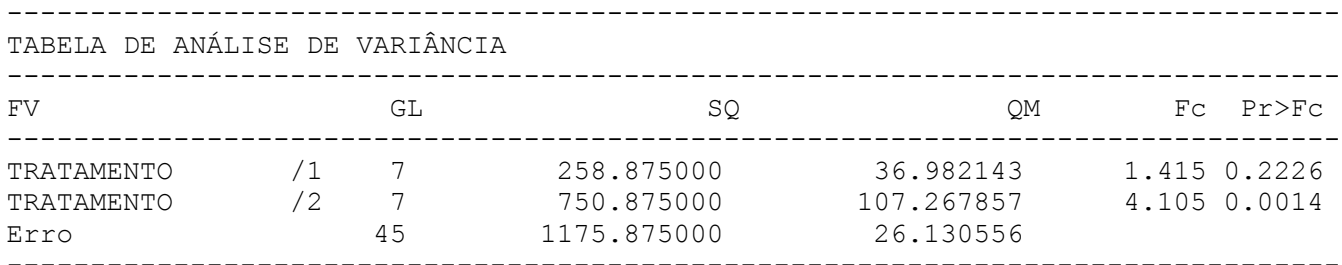

Codificação usada para o desdobramento

COd. SEMENTE

$1=$ SEMENTE BÁSICA 2 = SEMENTE INOCULADA 
Variável analisada: NÚMERO DE GRÃOS POR PARCELA

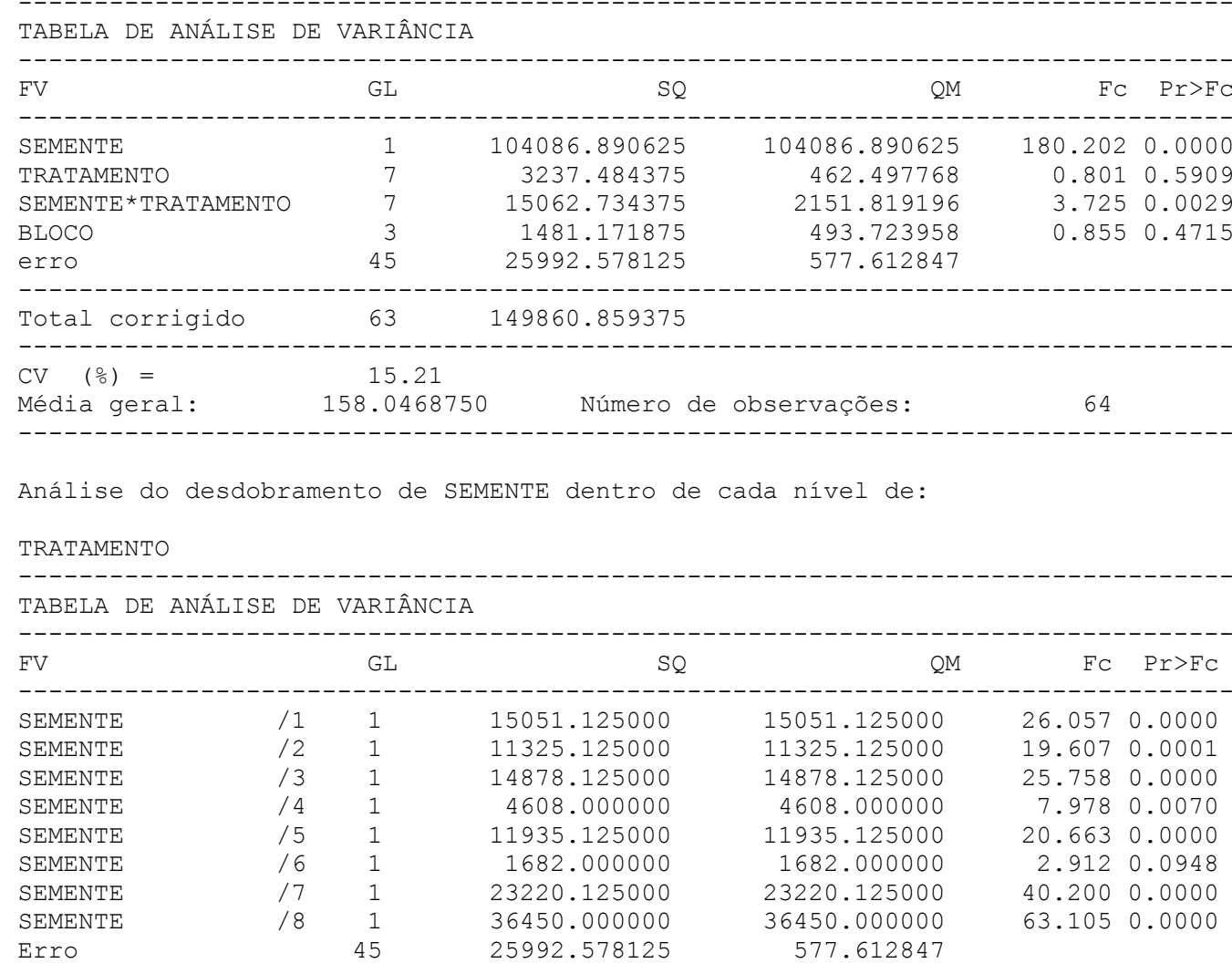

Codificação usada para o desdobramento

cod. TRATAMENTO

$1=$ COBRE 2 = CASUGAMICINA 3 = ÁCIDO PERACÉTICO 4 = CLORETOS DE BENZALCÔNIO $5=$ VAPOR ETANOL 6

= VAPOR METANOL 7 = OZÔNIO 8 = SEM TRATAMENTO.

Análise do desdobramento de TRATAMENTO dentro de cada nível de:

SEMENTE

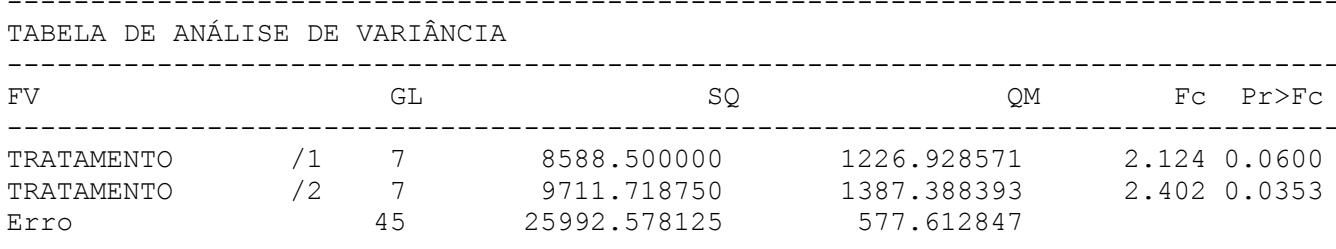

Codificação usada para o desdobramento

COd. SEMENTE

$1=$ SEMENTE BÁSICA 2 = SEMENTE INOCULADA 


\section{Variável analisada: NÚMERO DE GRÃOS ABORTADOS POR VAGEM}

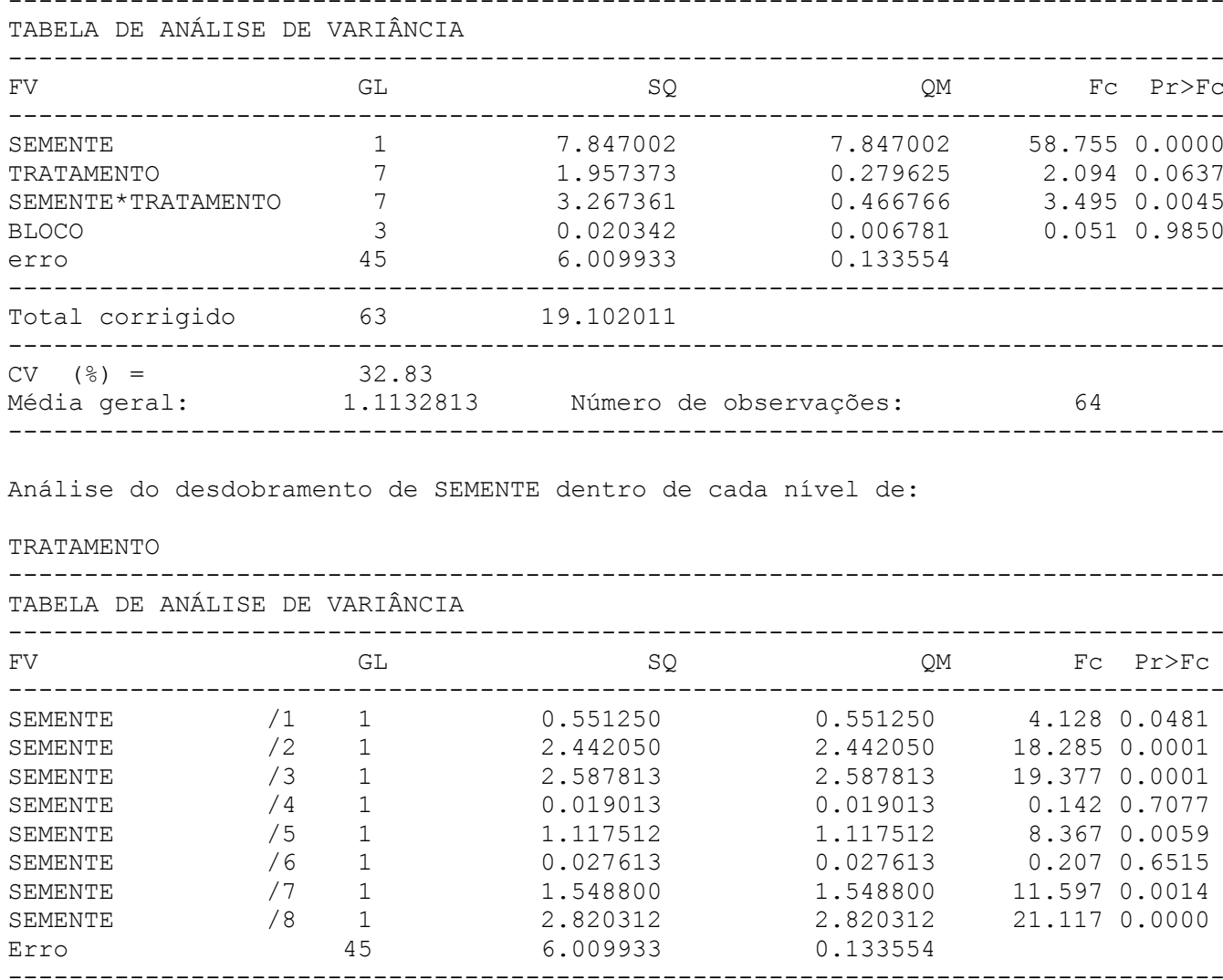

Codificação usada para o desdobramento cod. TRATAMENTO

$1=$ COBRE 2 = CASUGAMICINA 3 = ÁCIDO PERACÉTICO 4 = CLORETOS DE BENZALCÔNIO 5 = VAPOR ETANOL 6 = VAPOR METANOL 7 = OZÔNIO 8 = SEM TRATAMENTO.

Análise do desdobramento de TRATAMENTO dentro de cada nível de:

SEMENTE

\begin{tabular}{|c|c|c|c|c|}
\hline FV & GL & $\mathrm{SQ}$ & $Q \mathrm{M}$ & $\mathrm{FC} \quad \mathrm{Pr}>\mathrm{FC}$ \\
\hline TRATAMENTO & /1 & 0.327888 & 0.046841 & $0.351 \quad 0.9254$ \\
\hline TRATAMENTO & 12 & 4.896847 & 0.699550 & $5.238 \quad 0.0002$ \\
\hline rro & 45 & 6.009933 & 0.133554 & \\
\hline
\end{tabular}

Codificação usada para o desdobramento cod. SEMENTE

1 = SEMENTE BÁSICA 2 = SEMENTE INOCULADA 


\section{Variável analisada: PORCENTAGEM DE SEMENTES ABORTADAS}

\begin{tabular}{|c|c|c|c|c|c|}
\hline FV & GL & $\mathrm{SQ}$ & $\mathrm{QM}$ & $\mathrm{FC}$ & Pr $>$ FC \\
\hline EMENTE & 1 & 3099.148900 & 3099.148900 & 101.204 & 0.0000 \\
\hline RATAMENTO & 7 & 346.566775 & 49.509539 & 1.617 & 0.1553 \\
\hline SEMENTE*TRATAMENTO & 7 & 874.982800 & 124.997543 & 4.082 & 0.0015 \\
\hline $\mathrm{LOCO}$ & 3 & 44.704438 & 14.901479 & 0.487 & 0.6933 \\
\hline rro & 45 & 1378.027863 & 30.622841 & & \\
\hline otal corrigido & 63 & 5743.430775 & & & \\
\hline $\begin{array}{l}\mathrm{CV}\left(\frac{\circ}{0}\right)= \\
\text { Média geral: }\end{array}$ & $\begin{array}{c}24.53 \\
22.5618750\end{array}$ & Número $\mathrm{d}$ & ervações: & 64 & \\
\hline
\end{tabular}

Análise do desdobramento de SEMENTE dentro de cada nível de:

TRATAMENTO

\begin{tabular}{|c|c|c|c|c|c|c|}
\hline $\mathrm{FV}$ & & GL & $S Q$ & $\mathrm{QM}$ & FC & $\mathrm{Pr}>\mathrm{FC}$ \\
\hline SEMENTE & $/ 1$ & 1 & 328.448450 & 328.448450 & 10.726 & 0.0020 \\
\hline SEMENTE & 12 & 1 & 633.680000 & 633.680000 & 20.693 & 0.0000 \\
\hline SEMENTE & 13 & 1 & 749.812812 & 749.812812 & 24.485 & 0.0000 \\
\hline SEMENTE & $/ 4$ & 1 & 0.667013 & 0.667013 & 0.022 & 0.8833 \\
\hline SEMENTE & $/ 5$ & 1 & 444.467112 & 444.467112 & 14.514 & 0.0004 \\
\hline SEMENTE & 16 & 1 & 26.645000 & 26.645000 & 0.870 & 0.3559 \\
\hline EMENTE & $/ 7$ & 1 & 781.508113 & 781.508113 & 25.520 & 0.0000 \\
\hline SEMENTE & 18 & 1 & 1008.903200 & 1008.903200 & 32.946 & 0.0000 \\
\hline Erro & & 45 & 1378.027863 & 30.622841 & & \\
\hline
\end{tabular}

Codificação usada para o desdobramento cod. TRATAMENTO

$1=$ COBRE 2 = CASUGAMICINA 3 = ÁCIDO PERACÉTICO 4 = CLORETOS DE BENZALCÔNIO 5 = VAPOR ETANOL 6 = VAPOR METANOL 7 = OZÔNIO 8 = SEM TRATAMENTO.

Análise do desdobramento de TRATAMENTO dentro de cada nível de:

SEMENTE

TABELA DE ANÁLISE DE VARIÂNCIA

\begin{tabular}{|c|c|c|c|c|c|}
\hline FV & & GL & $S Q$ & $\mathrm{QM}$ & $\mathrm{FC} \quad \mathrm{Pr}>\mathrm{FC}$ \\
\hline TRATAMENTO & $/ 1$ & 7 & 145.223687 & 20.746241 & $0.677 \quad 0.6898$ \\
\hline TRATAMENTO & 12 & 7 & 1076.325887 & 153.760841 & 5.0210 .0003 \\
\hline Erro & & 45 & 1378.027863 & 30.622841 & \\
\hline
\end{tabular}

Codificação usada para o desdobramento

cod. SEMENTE

$1=$ SEMENTE BÁSICA 2 = SEMENTE INOCULADA 


\section{Variável analisada: PRODUÇÃO POR PARCELA}

\begin{tabular}{|c|c|c|c|c|c|}
\hline FV & GL & $S Q$ & $\mathrm{QM}$ & FC & $\mathrm{Pr}>\mathrm{FC}$ \\
\hline EMENTE & 1 & 15972.852264 & 15972.852264 & 244.401 & 0.0000 \\
\hline RATAMENTO & 7 & 540.778398 & 77.254057 & 1.182 & 0.3321 \\
\hline SEMENTE*TRATAMENTO & 7 & 1429.487173 & 204.212453 & 3.125 & 0.0089 \\
\hline LOCO & 3 & 144.054392 & 48.018131 & 0.735 & 0.5368 \\
\hline erro & 45 & 2940.974983 & 65.355000 & & \\
\hline otal corrigido & 63 & 21028.147211 & & & \\
\hline $\begin{array}{l}\mathrm{CV}\left(\frac{\circ}{\circ}\right)= \\
\text { Média geral: }\end{array}$ & $\begin{array}{c}16.68 \\
48.4732813\end{array}$ & Número $\mathrm{d}$ & servacões: & 64 & \\
\hline
\end{tabular}

Análise do desdobramento de SEMENTE dentro de cada nível de:

TRATAMENTO

TABELA DE ANÁLISE DE VARIÂNCIA

\begin{tabular}{|c|c|c|c|c|c|c|}
\hline FV & & GL & $S Q$ & $\mathrm{QM}$ & $\mathrm{FC}$ & Pr $>$ FC \\
\hline SEMENTE & $/ 1$ & 1 & 1988.912450 & 1988.912450 & 30.432 & 0.0000 \\
\hline SEMENTE & 12 & 1 & 1516.903200 & 1516.903200 & 23.210 & 0.0000 \\
\hline SEMENTE & 13 & 1 & 2029.800613 & 2029.800613 & 31.058 & 0.0000 \\
\hline SEMENTE & 14 & 1 & 906.102450 & 906.102450 & 13.864 & 0.0005 \\
\hline SEMENTE & $/ 5$ & 1 & 1652.262613 & 1652.262613 & 25.281 & 0.0000 \\
\hline SEMENTE & 16 & 1 & 813.657800 & 813.657800 & 12.450 & 0.0010 \\
\hline SEMENTE & 17 & 1 & 3343.575313 & 3343.575313 & 51.160 & 0.0000 \\
\hline SEMENTE & 18 & 1 & 5151.125000 & 5151.125000 & 78.818 & 0.0000 \\
\hline Erro & & 45 & 2940.974983 & 65.355000 & & \\
\hline
\end{tabular}

Codificação usada para o desdobramento cod. TRATAMENTO

1 = COBRE 2 = CASUGAMICINA 3 = ÁCIDO PERACÉTICO 4 = CLORETOS DE BENZALCÔNIO 5 = VAPOR ETANOL 6 $=$ VAPOR METANOL 7 = OZÔNIO 8 = SEM TRATAMENTO.

Análise do desdobramento de TRATAMENTO dentro de cada nível de:

SEMENTE

TABELA DE ANÁLISE DE VARIÂNCIA

\begin{tabular}{|c|c|c|c|c|c|}
\hline FV & & GL & $\mathrm{SQ}$ & $Q \mathrm{M}$ & FC $\quad$ Pr $>$ FC \\
\hline TRATAMENTO & $/ 1$ & 7 & 1102.663550 & 157.523364 & $2.410 \quad 0.0347$ \\
\hline TRATAMENTO & 12 & 7 & 867.602022 & 123.943146 & 1.8960 .0922 \\
\hline Erro & & 45 & 2940.974983 & 65.355000 & \\
\hline
\end{tabular}

Codificação usada para o desdobramento

cod. SEMENTE

$1=$ SEMENTE BÁSICA 2 = SEMENTE INOCULADA 


\section{Variável analisada: NÚMERO DE GRÃOS POR VAGEM}

\begin{tabular}{|c|c|c|c|c|c|}
\hline FV & GL & SQ & $\mathrm{QM}$ & $\mathrm{FC}$ & $\operatorname{Pr}>\mathrm{FC}$ \\
\hline SEMENTE & 1 & 8.287202 & 8.287202 & 64.508 & 0.0000 \\
\hline TRATAMENTO & 7 & 0.752486 & 0.107498 & 0.837 & 0.5628 \\
\hline SEMENTE* TRATAMENTO & 7 & 0.898686 & 0.128384 & 0.999 & 0.4443 \\
\hline $\mathrm{BLOCO}$ & 3 & 0.735805 & 0.245268 & 1.909 & 0.1416 \\
\hline erro & 45 & 5.781020 & 0.128467 & & \\
\hline $\begin{array}{l}------------- \\
\text { otal corrigido }\end{array}$ & 63 & 16.455198 & & & \\
\hline $\begin{array}{l}\text { V }\left(\frac{\circ}{\circ}\right)= \\
\text { lédia geral: }\end{array}$ & $\begin{array}{l}9.55 \\
3.7548437\end{array}$ & Número d & ações: & 64 & \\
\hline
\end{tabular}

Análise do desdobramento de SEMENTE dentro de cada nível de:

TRATAMENTO

TABELA DE ANÁLISE DE VARIÂNCIA

\begin{tabular}{|c|c|c|c|c|c|c|}
\hline FV & & GL & $S Q$ & $\mathrm{QM}$ & FC & $\operatorname{Pr}>\mathrm{FC}$ \\
\hline SEMENTE & $/ 1$ & 1 & 1.786050 & 1.786050 & 13.903 & 0.0005 \\
\hline SEMENTE & 12 & 1 & 0.667013 & 0.667013 & 5.192 & 0.0275 \\
\hline SEMENTE & 13 & 1 & 1.110050 & 1.110050 & 8.641 & 0.0052 \\
\hline SEMENTE & $/ 4$ & 1 & 0.515113 & 0.515113 & 4.010 & 0.0513 \\
\hline SEMENTE & $/ 5$ & 1 & 0.535612 & 0.535612 & 4.169 & 0.0471 \\
\hline SEMENTE & 16 & 1 & 0.328050 & 0.328050 & 2.554 & 0.1170 \\
\hline SEMENTE & $/ 7$ & 1 & 2.163200 & 2.163200 & 16.839 & 0.0002 \\
\hline SEMENTE & 18 & 1 & 2.080800 & 2.080800 & 16.197 & 0.0002 \\
\hline Erro & & 45 & 5.781020 & 0.128467 & & \\
\hline
\end{tabular}

Codificação usada para o desdobramento cod. TRATAMENTO

1 = COBRE 2 = CASUGAMICINA 3 = ÁCIDO PERACÉTICO 4 = CLORETOS DE BENZALCÔNIO 5 = VAPOR ETANOL 6 $=$ VAPOR METANOL 7 = OZÔNIO 8 = SEM TRATAMENTO.

Análise do desdobramento de TRATAMENTO dentro de cada nível de:

SEMENTE

TABELA DE ANÁLTSE DE VARTÂNCIA

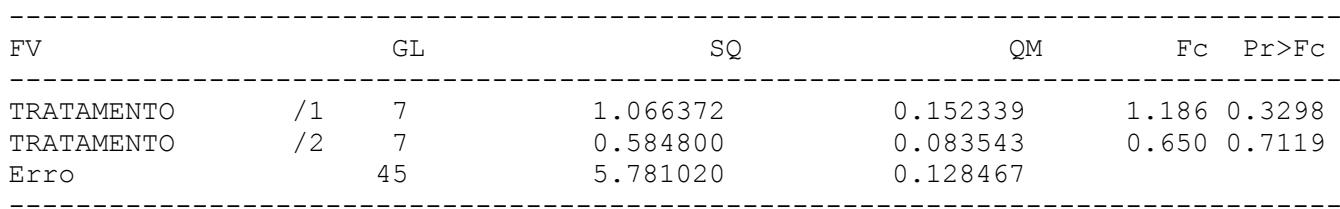

Codificação usada para o desdobramento

cod. SEMENTE

$1=$ SEMENTE BÁSICA 2 = SEMENTE INOCULADA 


\section{Variável analisada: NÚMERO DE GRÃOS POR GRAMA}

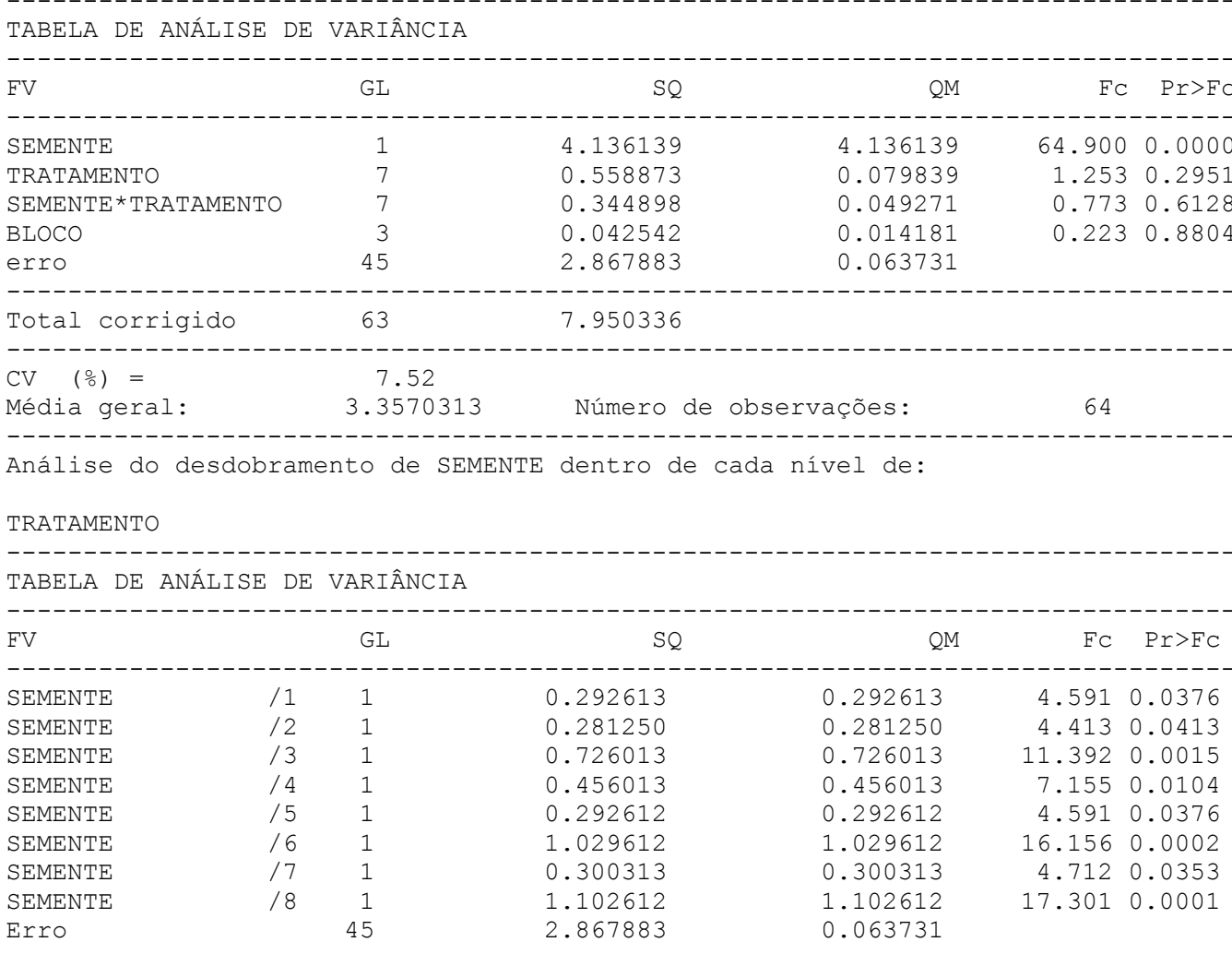

Codificação usada para o desdobramento

cod. TRATAMENTO

$1=$ COBRE 2 = CASUGAMICINA 3 = ÁCIDO PERACÉTICO 4 = CLORETOS DE BENZALCÔNIO 5 = VAPOR ETANOL 6

$=$ VAPOR METANOL 7 = OZÔNIO $8=$ SEM TRATAMENTO.

Análise do desdobramento de TRATAMENTO dentro de cada nível de:

SEMENTE

\begin{tabular}{|c|c|c|c|c|}
\hline FV & GL & $\mathrm{SQ}$ & $Q \mathrm{M}$ & $\mathrm{FC} \quad \mathrm{Pr}>\mathrm{FC}$ \\
\hline TRATAMENTO & $/ 1$ & 0.372772 & 0.053253 & $0.836 \quad 0.5634$ \\
\hline TRATAMENTO & 12 & 0.531000 & 0.075857 & $1.190 \quad 0.3273$ \\
\hline Erro & 45 & 2.867883 & 0.063731 & \\
\hline
\end{tabular}

Codificação usada para o desdobramento

COd. SEMENTE

1 = SEMENTE BÁSICA 2 = SEMENTE INOCULADA 
Variável analisada: INCIDÊNCIA (30 DAS)

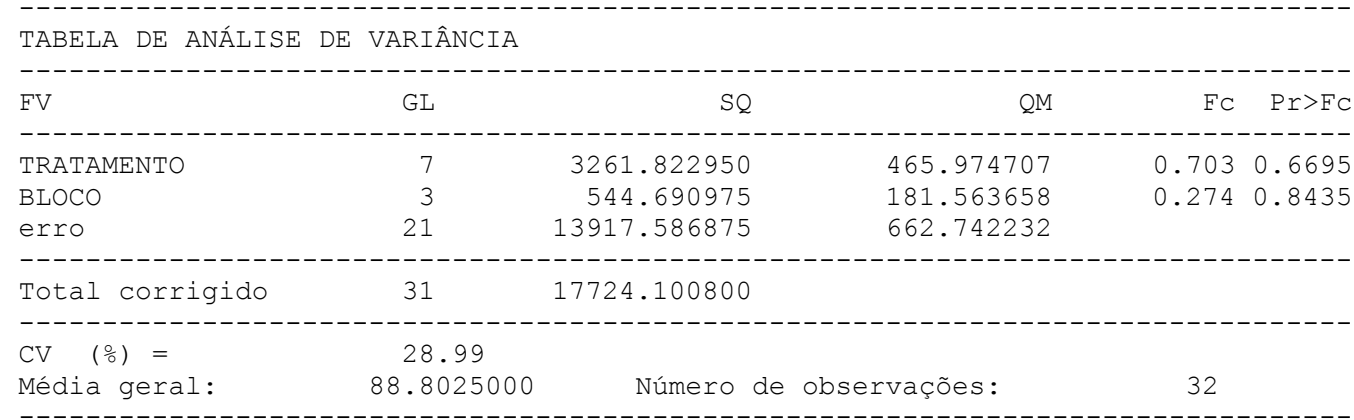

Variável analisada: INCIDÊNCIA (45 DAS)

TABELA DE ANÁLISE DE VARIÂNCIA

\begin{tabular}{|c|c|c|c|c|c|}
\hline FV & GL & SQ & $\mathrm{QM}$ & $\mathrm{EC}$ & $\operatorname{Pr}>\mathrm{FC}$ \\
\hline TRATAMENTO & 7 & 3574.218750 & 510.602679 & 1.356 & 0.2747 \\
\hline $\mathrm{BLOCO}$ & 3 & 683.593750 & 227.864583 & 0.605 & 0.6191 \\
\hline erro & 21 & 7910.156250 & 376.674107 & & \\
\hline-------------- & -------- & -------------- & ----------- & & \\
\hline otal corrigido & 31 & 12167.968750 & & & \\
\hline $\mathrm{V} \quad(\%)=$ & 20.53 & & & & \\
\hline Média geral: & 94.5312500 & Número de & rvações: & 32 & \\
\hline
\end{tabular}

\section{Variável analisada: INCIDÊNCIA (60 DAS)}

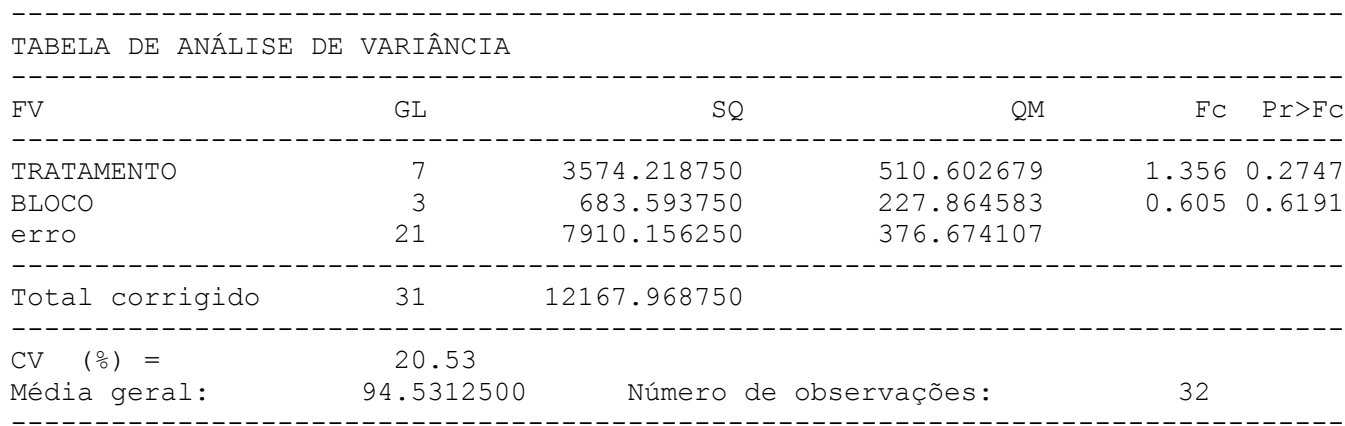




\section{Variável analisada: SEVERIDADE (30 DAS)}

\begin{tabular}{|c|c|c|c|c|c|}
\hline FV & GL & $S Q$ & $Q \mathrm{M}$ & FC & $\operatorname{Pr}>\mathrm{FC}$ \\
\hline RATAMENTO & 7 & 8.524197 & 1.217742 & 0.558 & 0.7808 \\
\hline LOCO & 3 & 3.325684 & 1.108561 & 0.508 & 0.6809 \\
\hline erro & 21 & 45.805391 & 2.181209 & & \\
\hline Total corrigido & 31 & 57.655272 & & & \\
\hline $\begin{array}{l}\mathrm{CV} \quad\left(\frac{\circ}{0}\right)= \\
\text { Média geral: }\end{array}$ & $\begin{array}{c}42.21 \\
3.4990625\end{array}$ & Número $\mathrm{d}$ & ações: & 32 & \\
\hline
\end{tabular}

Variável analisada: SEVERIDADE (45 DAS)

TABELA DE ANÁLISE DE VARIÂNCIA

\begin{tabular}{|c|c|c|c|c|c|}
\hline FV & GL & $\mathrm{SQ}$ & $\mathrm{QM}$ & $\mathrm{FC}$ & Pr $>$ FC \\
\hline TRATAMENTO & 7 & 11.717222 & 1.673889 & 0.597 & 0.7510 \\
\hline $\mathrm{BLOCO}$ & 3 & 6.461109 & 2.153703 & 0.769 & 0.5244 \\
\hline erro & 21 & 58.841316 & 2.801967 & & \\
\hline Total corrigido & 31 & 77.019647 & & & \\
\hline $\begin{array}{l}\mathrm{CV}\left(\frac{\circ}{\circ}\right) \\
\text { Média geral: }\end{array}$ & $\begin{array}{l}30.36 \\
5.5128125\end{array}$ & Número de & ções: & 32 & \\
\hline
\end{tabular}

Variável analisada: SEVERIDADE (60 DAS)

TABELA DE ANÁLISE DE VARIÂNCIA

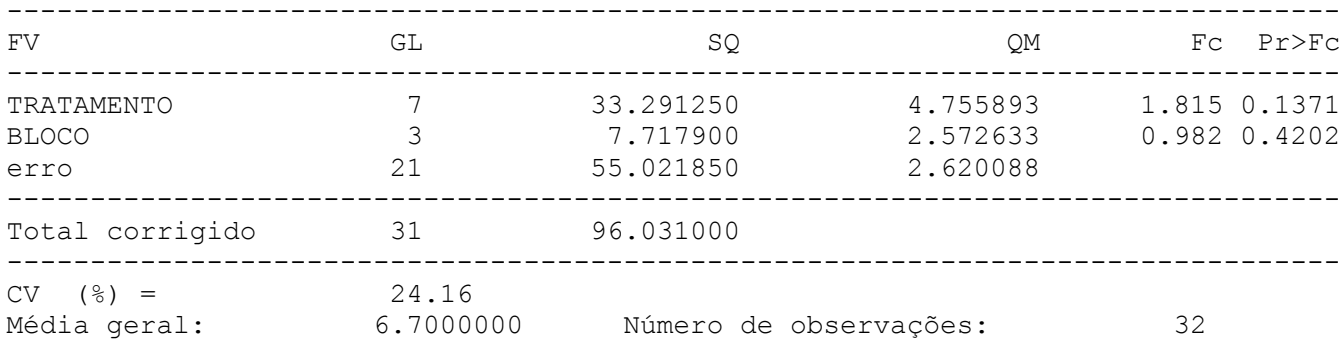

Variável analisada: ÁREA ABAIXO DA CURVA DE PROGRESSO DA MURCHA DE CURTOBACTERIUM (AACPMC)

TABELA DE ANÁLISE DE VARIÂNCIA

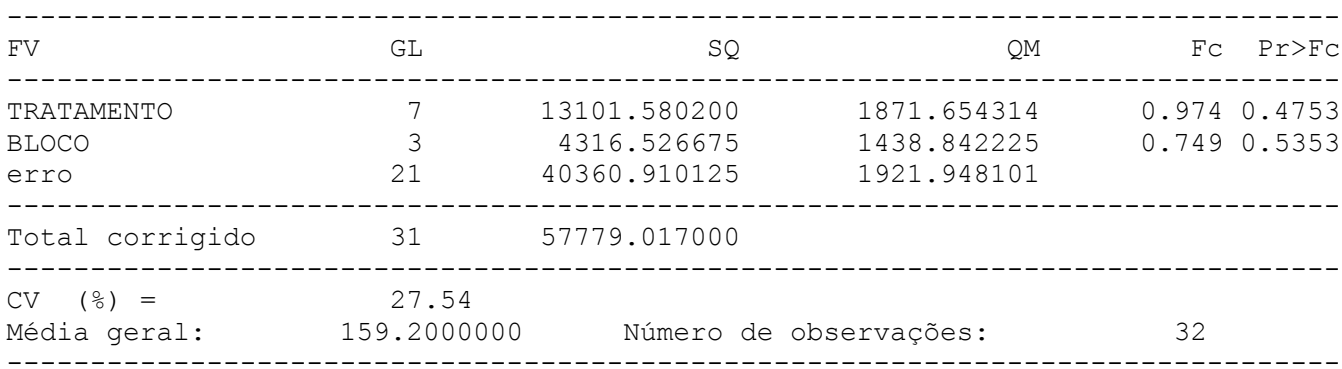

